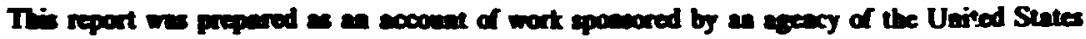

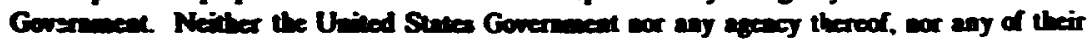

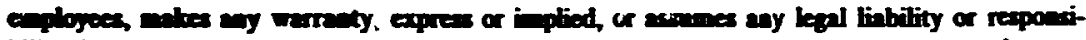

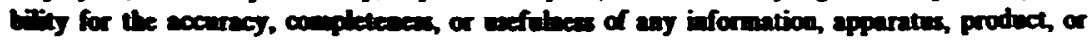

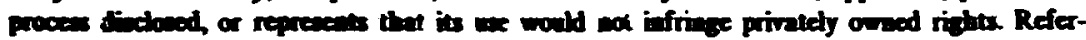

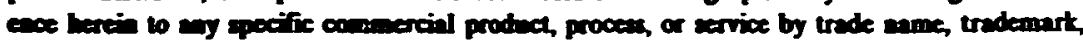

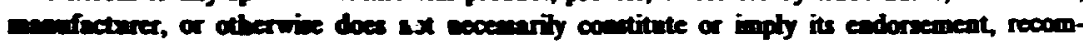
cendetion, or favides by the Unitod Stutes Government or any afeacy thereof. The views

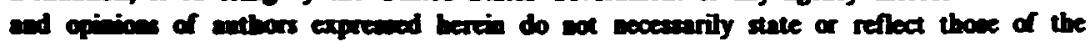

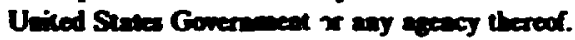

ORNL/CSD/TM-223

K/HS-74

\title{
VALIDATION OF KENO VA AND TWO CROSSSECTICN LIBRARIES FOR CRITICALITY CALCULATIONS OF LOW-ENRICHED URANIUM SYSTEMS
}

M. E. Easter

ORNL/CSD/TM--223

DE85 018148

Date Pabliched - Joly 1985

\section{COMPUTING AND TELECOMMUNICATIONS DIVISION}

at

Oak Rike National Laboratory

Post Ofice Bsx X

Oak Ridete, TN 37831

Martion Mariette Enercy Systema, Inc.

operation the

Oak Ribe National Laboratory

Onk Ritize Y-12 Plant
Oak Ridge Gaceons Diffocion Plant

Padrcaln Gaseons Diffecion Plant

ender Contract No. ACOS-840R21400

for the

DEPARTMENT OF ENERGY 


\section{CONTENTS}

ACKNOWLEDGEMENTS $\ldots \ldots \ldots \ldots \ldots \ldots \ldots \ldots \ldots \ldots \ldots \ldots \ldots \ldots \ldots \ldots$

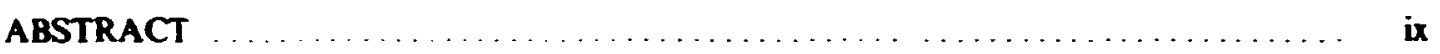

SUMMARY

1. INTRODUCTION $\ldots \ldots \ldots \ldots \ldots \ldots \ldots \ldots \ldots \ldots \ldots \ldots \ldots \ldots \ldots \ldots \ldots$

2. DESCRIPTION OF EXPERIMENTS $\ldots \ldots \ldots \ldots \ldots \ldots \ldots \ldots \ldots \ldots \ldots \ldots \ldots \ldots \ldots 2$

2.1 Y-1948 CRITICAL EXPERIMENTS $\ldots \ldots \ldots \ldots \ldots \ldots \ldots \ldots \ldots \ldots \ldots \ldots$

2.2 ROCKY FLATS PLANT CRITICAL EXPERIMENTS $\ldots \ldots \ldots \ldots \ldots \ldots \ldots .5$

3. Calculational METHOD $\ldots \ldots \ldots \ldots \ldots \ldots \ldots \ldots \ldots \ldots \ldots \ldots \ldots \ldots$

4. VALIDATION OF KENO V.a AND TWO CROSS-SECTION LIBRARIES $\ldots \ldots \ldots \ldots \ldots \ldots \ldots \ldots \ldots \ldots \ldots \ldots \ldots \ldots \ldots \ldots$

5. TESTS FOR TRENDS AND BIASES $\ldots \ldots \ldots \ldots \ldots \ldots \ldots \ldots \ldots \ldots \ldots \ldots \ldots$ I4

6. RESULTS AND CONCLUSIONS $\ldots \ldots \ldots \ldots \ldots \ldots \ldots \ldots \ldots \ldots \ldots \ldots \ldots \ldots$

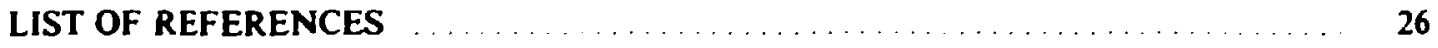

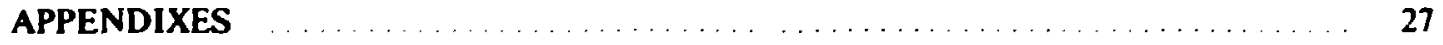

APPENDIX A DESCRIPTION OF SCALE CODE SYSTEM $\ldots \ldots \ldots \ldots \ldots \ldots \ldots .28$

APPENDIX B COMPARISON OF NUMBER

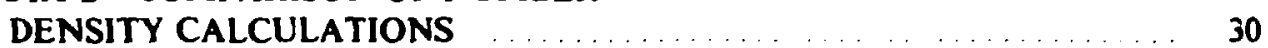

APPENDIX C CODE INPUT FOR ALL CASES $\ldots \ldots \ldots \ldots \ldots \ldots \ldots$

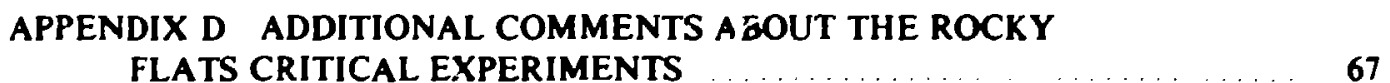

APPENDIX E CALCULATION OF TOLERANCE LIMITS $\ldots \ldots \ldots \ldots \ldots$ 
FIGURE

PAGE

6.I ker (16-group) versus AE, linear model and lower tolerance limit

$6.2 k_{\text {enf }}$ (27-group) versus $H::^{235} \mathrm{U}$ for $\mathrm{U}(1.4)$, linear mcdel and lower tolerance limit

$6.3 K_{\text {eff }}$ (27-group) versus $H_{:}^{235} \mathrm{U}$ for $\mathrm{U}(2.0)$, linear model and lower tolerance limit

$6.4 k_{e-1}(27-g r o u p)$ versus $H::^{235} U$ for $U(3.0)$, linear model and lower tolerance limit

$6.5 K_{\text {ef }}$ (27-group) versus $H_{:}^{-235} U$ for $U(4.98)$, linear madel and bower tolerance limit

6.6 $k_{\text {eft }}$ (27-group) versus AE for U(1.4). linear model and lower tolerance limit

6.7 $k_{\text {eff }}$ (27-group) vetsus at tor U(2.0), linear model and lower tolerance limit

6.8 ker (27-group) versus AE for U(3.0), linear model and lower tolerance limit

6.9 $k_{\text {efi }}$ (27-group) versus $A^{*}$; for $U(4.98)$, linear model and lower tolerance limit

D.I North split table reflector map showing location of non-fire retardent Plexiglas

D.2 South split table reflector map showing location of non-fire retardent Plexiglas

D.3 Dimensions of north split table reflector used in computer models

D 4 Dimensions of south split table reflector used in computer models

E.1 Plot of example data with linear model and lower tolerance limit 


\section{LIST OF TABLES}

TABLE

PACE

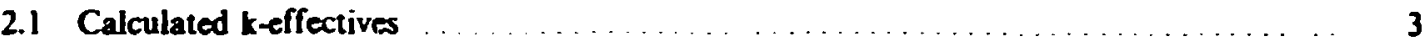

4.I Comparison of KENO V.a with KENO IV using the 27-group library $\ldots \ldots \ldots \ldots$

4.2 Comparison of KENO V.a with KENO IV using the 16-group library $\ldots \ldots \ldots \ldots$

4.3 KENO V.a with defauh histories and modified histories

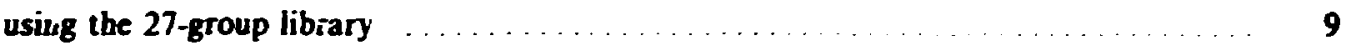

4.4 KENO V.a with default histories and modified histories

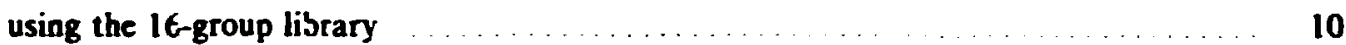

4.5 KENO V.a with and without reflector biasing using the 27-group library $\ldots \ldots \quad 10$

4.6 KENO V.a with and without reflector biasing using the 16-group library $\ldots \ldots \ldots 10$

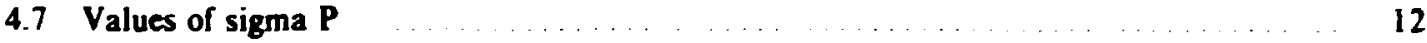

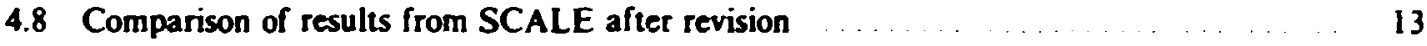

5.1 Experiment parameters considered in trend analysis $\ldots \ldots \ldots \ldots \ldots \ldots \ldots$

5.2 Correlation coefficients and significance levels obtained by comparing experiment parameters with results from 27 -group and

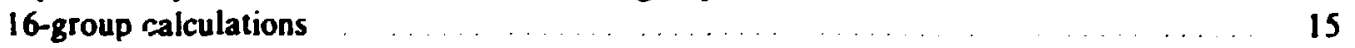

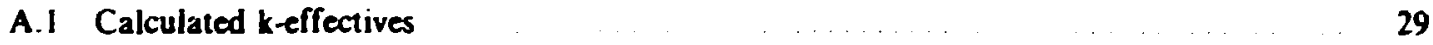

B.1 Comparison of numbei densities 30

D.1 Hydrogenous material in fuel at $\mathrm{H} / \mathrm{U}=0.77 \quad 68$

D.2 Comparison of $\mathrm{H}: \mathrm{U}$ values $\quad 68$

E.1 Example daca $\quad 75$ 
s

The author is grateful to the following for their belp and support in preparing this report: H. R. Dyer, R. M. Westfall, and H. L. Dodds for defining the project and directing my work, L. M. Petrie, N. C. Landers and J. C. Turner for their many consultations on the application of KENO V.a, and Lindy Norris for preparing the text.

This work was supported by Health, Safety and Environmental Affairs Division of the Oak Ridge Gaseous Diffusion Plant under account number 1207-0002. 


\begin{abstract}
AESTRACT
The SCALE' code system, utilizing the Monie Carlo computer code KENO V.a, ${ }^{2}$ was employed to caiculate 37 critical experimerits The critical assemblies had ${ }^{235} \mathrm{U}$ enrichments of $5 \%$ or less and cover a variety of geometries and miterials. Values of $k_{\text {eff }}$ were calculated using two different cross-section libraries for each experiment te determine if certain experimental parameters affected results using either of the cross-section libraries. The !6-energy-group Hansen-Roach and the 27-energy-group ENDF/B-IV cross-section libraries, available in SCALE, were used in this validation study, and both give good results for the experiments considered. It is conzluded that the code and cross sections are adequate for low-enriched uranium systems ar 4 that reliable criticality safety calculations can be made for such systems provided the limits of validated applicability are not exceeded.
\end{abstract}




\section{SUMMARY}

Recently a new version of the KENO Monte Carlo criticality code was released for testing. This new version, KENO $V_{.2,}{ }^{2}$ is an extensive revision of KENO IV $^{3}$ and includes an improved geometry pactage. The purpose of this work is to validate" the SCALE' version of the KENO V.a criticality code when useri with either 16-energy-group Hansen-Roach or 27-energygroup ENDF/B-IV cross sections for low-eariched uranium systems. The effective neutron multiplication factor, kfi. was calculated for 37 critical assemblies which have ${ }^{235} U$ earichments of 5\% or less. Some of the critical assemblies were included in an earliet validation report by Handley and Hogpers and some were taken from a series of intorstitially moderated and plexiglas reflected damp $\mathrm{U}_{3} \mathrm{O}_{2}$ experiments performed at the Rocky Flats Plant ${ }^{6-3}$ (RFP).

The RFP criticals are of interest because of their low $\mathrm{H}^{235} \mathrm{U}$ atomic ratios $(<50)$. However, these results cannot be compared directly with results from the other experiments because of the heterogeneous effect of the interstitial moderator. Eight RFP experiments were modeled, four were optimum-moderated $(244-\mathrm{cm}$-thick interstitial moderator) and the ocher four were undermoderated (0.929-cm-thick interstitial moderator). It is noted that the $k_{\text {ff }}$ 's calculated using Hansen-Roach cross sections are consistently higher than the ENDF/B-IV kfris for all of the Rocky Flats criticals.

For the 29 experiments cornmon to this study and Ref. 5, : 1 effort has been macie to define trends in $k_{\text {ef }}$ relative to the experimental parameters. The param ters investigated include $H_{:}^{235} \mathrm{U}$ atom ratio, $H_{:}^{238} \mathrm{U}$ atom ratio, and enrichment. Also, the average energy of a neutron causing fission weighted by energy group number (AE), a calculated parameter, was used to investigate trends. This parameter was used in an earlier validation report' and consists of summing the products of energy group number times the fission fraction for that group and then dividing by the sum of the fission fractions. However, tine calculated parameter and the $\mathrm{H}^{235} \mathrm{U}$ atom ratio cannot be considered independent because there is a strong correlation between the two.

The values of $k_{\text {enl }}$ calculated using 27-group ENDF/B-IV cross-section data show a strong correlation with H:U-235 ratio, average energy, and enrichment. Two linear models developed to describe these trends are:

1) $k_{n t}=1.0098-2.9875 E-5^{*}\left(H_{:}^{235} U\right)+2.2407 E-3^{*}$ (enrichment)

2) $k_{e-1}=1.1710-7.6653 E-3^{*}$ (AE) $+4.1472 E-3^{*}$ (enrichment).

The first model employs $\mathrm{H}:{ }^{235} \mathrm{U}$ and enrichment and accounts for $61 \%$ of the variation in 29 experiments, while the second nodel uses average energy and enrichment and accounts for $59 \%$ of the variation in the same 29 experiments. The mean value for all 29 experiments using the 27-group data is 1.0053 with standard deviation 0.0096 .

The values of $k_{\text {erl }}$ calculated using 16-group cross-section data exhibit a correlation with only one parameter, avcrage energy. This trend is described by the following linear model:

$$
k_{\text {eff }}=1.2267-1.5297 \mathrm{E}-2^{*} \text { (AE) }
$$

This model accounts for $59 \%$ of the variation in 29 experiments. The mean value for all 29 experiments using Hansen-Roach data is 0.9997 with standard deviation 0.0094 .

The results of this work indicate that trends in $k_{\text {en }}$ obtained using KENO V.a with 16-group Hansen-Roach data can be generally described by a linear model for the validated range of average energy. Similarly, when using KENO V.a with the 27-group ENDF/B-IV data, trends in $k_{\text {err }}$ can be generally described by linear models which depend on the validated range of $\mathrm{H}^{233} \mathrm{U}$ atomic ratio. :verage energy group. and enrichment. Both cross-section sets used with KENO V.a provide good agreement with experimental results for low-enriched uranium systems. 


\section{INTRODUCTION}

In order to analyze nuclear criticality safety without undue conservatism or expense, experimental data are often supplen ented by calculations. Therefore, each calculational method must be correlated with relevant experimental data in order to extablish a bias (if one exists) in the method over a specific area of applicability. The Oak Ridee Gaseons Difiusion Plant (ORGDP) Criticality Safety Group has previously used KENO IV for riticality safety calculations of plant operations. With the introduction of KENO V.a, which is an extensive revision of KENO IV, ORGDP has decided to validate KENO V.a as found in the SCALE code system (see Appendix A for a brief description of SCALE). This validation effort will allow the application of KENO V.a in the analysis of bow-eariched (<5\%) uranium systerns commonly found at ORGDP.

The purpose of this investigation is twofold, first to determine biases in calculated $k$ ar's for systems with uranium enrichments of 5\% or less and, second, to validate a standardized procedure for performing criticality caiculations. The effort to standardize criticality calculations utilizes the CSAS25 control module available in SCALE. This module requires a minimal aniount of engineering data about the problem $t$, run a successful calculation. From the input data, the control module calculates atomic number densities and certain resonance parameters; then it calls an established sequence of functional modules to process the cross sections and perform the criticality calculation. A check on the number densities calculated by SCALE is included in Appendix B.

The KENO V.a code was also validated by the Oak Ridge Y-12 plant for applications os systems of highly enriched uranium. A fmzen version of the SCALE code system, containing the KENO V.a code and all the programs and cross-section data used by SCALE, was prepared by ithe Oak Ridge National Laboratory Computer Sciences Division to be used in the Y-12 validation. This special SCALE package was named Y12CSG and is under the control of the Y-12 Criticality Safety Group for quality assu ance purposes. The same version of SCALE was used in this validation because of the strict quality assurance precautions taken by the $\mathrm{Y}-12$ plant.

A total of 37 low-enriched, experimentally critical systems applicable to the ORGDP, were modeled. Each experiment was modeled using the 16-group Tansen-Roach library and the 27-group ENDF/B-IV library yielding two values of $\boldsymbol{k}_{\text {eff }}$ for each experiment. Appendix $C$ contains listings for all experiments modeled, and Appendix D contains some additional information about the Rocky Flats Plant criticals. 


\section{DESCRIPTION OF EXPERIMINTS}

Included in this section are descriptions of the aritical experiments and the ken calculated by KENO V.a (see Table 2.1). The first part of this section describus the experiments investigated in Ref. 5 and employs the same notation for case number. Experiments in Ref. 5 were excluded if experimer.. documentation could not be found or if they were not of interest. Proper documentation could not be found for cases 1, 2, 3, 7, 8, 9, and 10 in Ref. 5. Pipe intersections found in cases 37, 38, 39, and 40 are not included since the frozen version of KENO V.a does not include generalized geometry.

The sexond part of this section describes low-enriched damp oxide (i.e., $\mathrm{H}^{2.23} \mathrm{U}<50$ ) experiments that are of special interest because of limited analysis previously available in this area. These experiments were performed at the RFP using fuel cubes 6 inches on a side at three different H:U atomic ratios. ${ }^{6-8}$ Cases 41 through 48 consist of eight interstitially moderated and Flexiglas reflected damp oxide experiments.

\section{Y-1948 CRITICAL EXPERMIENTS}

Case 4 - An unreflected rectangular parallelepiped of homogeneous $U(1.4) F_{4}$ and paraffin with a $H^{235} \mathrm{U}$ aiomic ratio of 421.8 . Dimensions of the homogenized assembly are $93.1 \mathrm{~cm} \times$ $93.0 \mathrm{~cm} \times 123.8 \mathrm{~cm}$ (Ref. 5).

Case 5 - An unreflected rectangular parallelepiped of homogeneous $U(1.4) F_{4}$ and parafin with a $\mathrm{H}:{ }^{235} \mathrm{U}$ atomic ratio of 421.8. Dimensions of the homogenized assembly are $100.0 \mathrm{~cm} \mathrm{x}$ $99.9 \mathrm{~cm} \times 103.1 \mathrm{~cm}$ (Ref. 5).

Case 6 - An unreflected rectangular parallelepiped of homogeneous $U(1.4) F_{4}$ and paraffin with a $H:{ }^{233} \mathrm{U}$ atomic ratio of 421.8 . Dimensions of the homogenized assembly are $130.7 \mathrm{~cm} x$ $130.6 \mathrm{~cm} \times 74.2 \mathrm{~cm}($ Ref. 5$)$.

Case 11 - A reflected rectanguiar parallelepiped of homogeneous $U(2) F_{4}$ and paraffin with a H: $:{ }^{233} \mathrm{U}$ atomic ratio of 195.2. Dimensions of the homogenized fuel assembly are $56.22 \mathrm{~cm} \times$ $56.22 \mathrm{~cm} \times 112.88 \mathrm{~cm}$, reflected with $15.2 \mathrm{~cm}$ of paraffin on top and sides and $15.2 \mathrm{~cm}$ of Plexiglas on the bottom (Ref. 5).

Case 12 - An unreflected rectangular parallelepiped of homogeneous $U(2) F_{4}$ and paraffin with a H: ${ }^{235} \mathrm{U}$ atomic ratio of 195.2. Dimensions of the homogenized fuel assembly are $56.22 \mathrm{~cm} \times$ $56.22 \mathrm{~cm} \times 112.88 \mathrm{~cm}$ (Ref. 5).

Case 13 - A reflected rectangular parallelepiped of homogeneous $U(2) F_{4}$ and paraffin with a $\mathrm{H}^{2}{ }^{233} \mathrm{U}$ atomic ratio of 293.9. Dimensions of the homogenized fuel assembly are $51.11 \mathrm{~cm} \times$ $51.11 \mathrm{~cm} \times 73.87 \mathrm{~cm}$, reflected with $15.2 \mathrm{~cm}$ of paralfin on top and sides ans $15.2 \mathrm{~cm}$ of Plexiglas on the bottom (Ref. 5).

Case 14 - An unreflected rectangular parallelepiped of homogeneous $\mathrm{U}(2) \mathrm{F}_{4}$ and paraffin with a $\mathrm{H}:{ }^{233} \mathrm{U}$ atomic ratio of 293.9. Dimensions of the homogenized fuel assembly are $56.22 \mathrm{~cm} \times$ $56.22 \mathrm{~cm} \times 122.47 \mathrm{~cm}$ (Ref. 5).

Case 15 - A reflected rectangular parallelepiped of homogeneous $U(2) F_{4}$ and paraffin with a $H^{.235} \mathrm{U}$ atomic ratio of 406.3 . Dimensiuns of the homogenized fuel assembly are $53.67 \mathrm{~cm} \times$ $53.67 \mathrm{~cm} \times 54.29 \mathrm{~cm}$, reflected with $15.2 \mathrm{~cm}$ of paraffin on top and sides and $15.2 \mathrm{~cm}$ of Plexiglas on the bottom (Ref. 5).

Case 16 - A reflected rectangular parallelepiped of homogeneous $U(2) F_{4}$ and paraffin with a H: $:{ }^{233} \mathrm{U}$ atomic ratio of 495.9 . Dimensions of the homogenized fuel assembly are $46.00 \mathrm{~cm} \times$ $46.00 \mathrm{~cm} \times 96.57 \mathrm{~cm}$, reflected with $15.2 \mathrm{~cm}$ of paraffin on top and sides and $15.2 \mathrm{~cm}$ of Plexigias on the bottom (Ref. 5).

Case 17 - A reflected rectangular parallelepiped of homogeneous $U(2) F_{4}$ and paraffin with a H: ${ }^{233} \mathrm{U}$ atomic ratio of 613.6 . Dimensions of the homogenized fuci assembly are $56.32 \mathrm{~cm} \times$ $61.29 \mathrm{~cm} \times 54.08 \mathrm{~cm}$, reflected with $15.2 \mathrm{~cm}$, of polyethylene on top and sides and $15.2 \mathrm{~cm}$ of Plexiglas on the bottom (Ref. 5). 
Table 2.1 Calculated $k$-effectives

\begin{tabular}{|c|c|c|c|c|c|}
\hline \multirow{3}{*}{$\begin{array}{l}\text { Case } \\
\text { no. } \\
04\end{array}$} & \multirow{3}{*}{$\frac{\text { Ref. }}{5}$} & \multicolumn{4}{|c|}{$k$-effecti-e \pm 1 sigma } \\
\hline & & \multicolumn{2}{|c|}{ ENDF/B-IV } & \multicolumn{2}{|c|}{ Hansen-Roach } \\
\hline & & $1.001 \pm$ & 0.003 & $0.996 \pm$ & 0.003 \\
\hline 05 & 5 & 0.992 & 0.003 & 0.998 & 0.003 \\
\hline 06 & 5 & 0.994 & 0.003 & 1.008 & 0.003 \\
\hline 11 & 5 & 0.998 & 0.004 & 0.996 & 0.004 \\
\hline 12 & 5 & 1.009 & 0.004 & 0.997 & 0.063 \\
\hline 13 & 5 & 0.999 & 0.004 & 1.003 & 0.003 \\
\hline 14 & 5 & 1.000 & 0.004 & 0.996 & 0.004 \\
\hline 15 & 5 & 0.998 & 0.004 & 1.001 & 0.004 \\
\hline 16 & 5 & 0.999 & 0.004 & 0.997 & 0.003 \\
\hline 17 & 5 & 0.996 & 0.003 & 0.984 & 0.003 \\
\hline 18 & 5 & 1.000 & 0.003 & 0.989 & 0.004 \\
\hline 19 & 5 & 0.992 & 0.002 & 0.995 & 0.003 \\
\hline 20 & 5 & 0.991 & 0.003 & 0.988 & 0.003 \\
\hline 21 & 5 & 1.016 & 0.004 & 1.014 & 0.004 \\
\hline 22 & 5 & 1.014 & 0.004 & 1.017 & 0.004 \\
\hline 23 & 5 & 1.022 & 0.005 & 1.009 & 0.005 \\
\hline 24 & 5 & 1.014 & 0.005 & 1.012 & 0.005 \\
\hline 25 & 5 & 1.014 & 0.005 & 1.010 & 0.005 \\
\hline 26 & 5 & 1.017 & 0.004 & 1.006 & 0.004 \\
\hline 27 & 5 & 1.016 & 0.004 & 1.019 & 0.004 \\
\hline 28 & 5 & 1.013 & 0.004 & 1.009 & 0.004 \\
\hline 29 & 5 & 1.015 & 0.004 & 0.995 & 0.005 \\
\hline 30 & 5 & 1.012 & 0.004 & 0.993 & 0.004 \\
\hline 31 & 5 & 1.021 & 0.004 & 1.001 & 0.005 \\
\hline 32 & 5 & 1.004 & 0.004 & 0.992 & 0.004 \\
\hline 33 & 5 & 0.993 & 0.004 & 1.000 & 0.004 \\
\hline 34 & 5 & 1.003 & 0.004 & 0.996 & 0.00 \\
\hline 35 & 5 & 1.009 & 0.004 & 0.986 & 0.004 \\
\hline 36 & 5 & 1.003 & $0 . \cos$ & 0.987 & 0.004 \\
\hline $1^{2}$ & 6 & 1.009 & 0.003 & 1.025 & 0.003 \\
\hline $2^{2}$ & 6 & 1.007 & 0.004 & 1.012 & $0 . r_{03}$ \\
\hline $3^{b}$ & 6 & 0.992 & 0.003 & 1.012 & 0.004 \\
\hline $1^{b}$ & 7 & 1.012 & 0.003 & 1.016 & 0.003 \\
\hline $2^{b}$ & 7 & 1.009 & 0.003 & 1.018 & 0.003 \\
\hline $3^{\circ}$ & 7 & 1.009 & 0.003 & 1.018 & 0.003 \\
\hline$F^{b}$ & 8 & 1.027 & 0.004 & 1.041 & 0.004 \\
\hline$G^{a}$ & 8 & 1.027 & 0.004 & 1.033 & 0.003 \\
\hline
\end{tabular}

-Optimum moderated experiment.

bUndermoderated experiment. 
Case 18 - An unreflected rectangular parallelepiped of homogeneous $U(2) F_{4}$ and paraffin with a $\mathrm{H}:{ }^{235} \mathrm{U}$ atimic ratio of 613.6 . Dimensions of the homogenized fuel assembly are $56.32 \mathrm{~cm} \times$ $61.29 \mathrm{cru} \times 54.08 \mathrm{~cm}$ (Ref. 5$)$.

Case 19 - A reflected rectangular parallelepiped of homogeneous $U(2) F_{4}$ and paraffin with a H: ${ }^{235} \mathrm{IJ}$ atomic ratio of 971.7 . Dimensions of the bomogenized fuel assembly are $76.51 \mathrm{~cm} x$ $76.44 \mathrm{~cm} \times 82.42 \mathrm{~cm}$, reflected wit' $15.2 \mathrm{~cm}$ of polyethylere on top and sides and $15.2 \mathrm{~cm}$ of Plexiglas on the bottcm (Ref. 5).

Case 20 - Ar: unreflected rectangular parallelepiped of homogeneous $U(2) F_{4}$ and paraffir with a H: ${ }^{235} \mathrm{U}$ atomic ratio of 971.7. Dinensions of the homogenized fual assembly are $81.45 \mathrm{~cm} x$ $86.70 \mathrm{~cm} \times 88.22 \mathrm{~cm}$ (Ref. 5).

Case 21 - A reflected rectangular parallelepiped of homogeneous $U(3) F_{4}$ and paraffin with a $H:{ }^{235} \mathrm{U}$ atomic ratio of 133.4 . Dimensions of the homogenized fuel assemhly are $51.14 \mathrm{~cm} x$ $51.14 \mathrm{~cm} \times 51.27 \mathrm{~cm}$, reflected with $15.2 \mathrm{~cm}$ of paraffin on top and sides and $15.2 \mathrm{~cm}$ of Plexiglas on the bottom (Ref. 5).

Case 22 - A reflected rectangular parallelepiped of homogeneous $U(3) F_{4}$ and faraffin with a H: ${ }^{235} \mathrm{U}$ atomic ratio of 133.4 . Dimensions of the homogenized fuel assembly are $43.47 \mathrm{~cm} \times$ $43.47 \mathrm{~cm} \times 86.39 \mathrm{~cm}$, reflected with $15.2 \mathrm{~cm}$ of paraffin on top and sides and $15.2 \mathrm{~cm}$ of Flexiglas on the bottom (Ref. 5).

Case 23 - A reflected rectangular parallelepiped of homogeneous $U(3) F_{4}$ and paraffin with a $\mathrm{H}:{ }^{235} \mathrm{U}$ atomic ratio of 133.4. Dimensions of the homogenized fuel assembly are $46.02 \mathrm{~cm} \times$ $46.02 \mathrm{~cm} \times 67.57 \mathrm{~cm}$, reflected with $15.2 \mathrm{~cm}$ of paraffin on $1 \mathrm{s,p}$ and sides and $15.2 \mathrm{~cm}$ of Plexiglas on the bottom (Ref. 5).

Case 24 - A : :flected rectangular parallelepiped of homogeneous $U(3) F_{4}$ and paraffin with a $\mathrm{H}:{ }^{235} \mathrm{U}$ atomic ratio of 133.4 . Dimensions of the homogenized fuel assembly are $56.25 \mathrm{~cm} x$ $56.25 \mathrm{~cm} \times 43.41 \mathrm{~cm}$, refected with $15.2 \mathrm{~cm}$ of paraffin on top and sides and $15.2 \mathrm{~cm}$ of Plexiglas un the bottom (Ref. 5).

Case 25 - A reflected rectangular parallelepiped of homogeneous $U(3) F_{4}$ and paraffin with a $\mathrm{H}^{2}{ }^{235} \mathrm{U}$ atomic ratio of 133.4 . Dimensions of the homogenized fuel assembly are $6: .36 \mathrm{~cm} \times$ $61.36 \mathrm{~cm} \times 38.67 \mathrm{~cm}$, reflected with $15.2 \mathrm{~cm}$ of paraffin on top and sides and $15.2 \mathrm{~cm}$ of Plexiglas on the bottom (Ref. 5).

Case 26 - An unreflected rectangular parallelepiped of homogeneous $U(3) F_{4}$ and paraffin with a $\mathrm{H}:{ }^{235} \mathrm{U}$ atomic ratio of 133.4. Dimensions of the homogenized fuel assembly are $56.47 \mathrm{~cm} \times$ $56.47 \mathrm{~cm} \times 86.64 \mathrm{~cm}$ (Ref. 5).

Case 27 - An unreflected rectangular parallelepiped of homogeneous $U(3) F_{4}$ and paraffin with a $\mathrm{H}:{ }^{235} \mathrm{U}$ atomic ratio of 133.4. Dimensions of the homogenized fuel assembly are $56.25 \mathrm{~cm} \times$ $61.36 \mathrm{~cm} \times 74.38 \mathrm{~cm}$ (Ref. S).

Case 28 - An unreflected rectangular parallelepiped of homogeneous $U(3) F_{4}$ and paraffin with a $\mathrm{H}:{ }^{235} \mathrm{U}$ atomic ratio of 133.4 . Dimensions of the homogenized fuel assembly are $61.40 \mathrm{~cm} \times$ $61.40 \mathrm{~cm} \times 66.00 \mathrm{~cm}$ (Ref. 5).

Case 29 - A reflected rectanjyular parallelepiped of homogeneous $\mathrm{U}(3) \mathrm{F}_{4}$ and paraffin with a H: ${ }^{235} \mathrm{U}$ atomic ratio of 276.9 . Dimensions of the homogenized fuel assembly are $40.81 \mathrm{~cm} \times$ $40.80 \mathrm{~cm} \times 39.49 \mathrm{~cm}$, reflected with $15.2 \mathrm{~cm}$ of polyethylene on top and sides and $15.2 \mathrm{~cm}$ of Plexiglas on the bottom (Ref. i).

Case 30 - An unreflected rectangular parallelepiped of homogeneous $U(3) F_{4}$ and paraffin with a $H .{ }^{235} \mathrm{U}$ atomic ratio of 276.9. Dimensions of the homogenized fuel assemblv are $40.90 \mathrm{~cm} \times$ $40.93 \mathrm{~cm} \times 116.80 \mathrm{~cm}$ (Ref. S).

Case 31 - An unreflected rectangular parallelepiped of homogeneous $U(3) F_{4}$ and paraffin with a $\mathrm{H}:{ }^{233} \mathrm{U}$ atomic ratio of 276.9 . Dimensions of the homogenized fuel assembly are $48.59 \mathrm{~cm} \times$ $51.14 \mathrm{~cm} \times 48.53 \mathrm{~cm}$ (Ref. 5 ).

Case 32 - An unreflected rectangular parallelepiped of homogen $1 u s \mathrm{U}(3) \mathrm{F}_{4}$ and paraffin with a $\mathrm{H}:{ }^{235} \mathrm{U}$ atomic ritio of 276.9 . Dimensions of the homogenized fuel assembly are $81.71 \mathrm{~cm} \mathrm{x}$ $81.66 \mathrm{~cm} \times 31.34 \mathrm{~cm}$ (Ref. 5). 
Case 33 - A composite cadmium/steel/water side reflected stainiess steel cylinder filled to a he: $z^{\text {tht }}$ of $54.45 \mathrm{~cm}$ with $\mathrm{U}(4.98) \mathrm{O}_{2} \mathrm{~F}_{2}$ solution at a $\mathrm{H}^{235} \mathrm{U}$ atomic ratio of 488 . The cylinder inner radius is $19.545 \mathrm{~cm}$ with wall thickness $0.079 \mathrm{~cm}$ and height $106.2 \mathrm{~cm}$. The adjacent reflector consisted of $0.002 \mathrm{~cm}$ of cadmium, $2.54 \mathrm{~cm}$ of steel, and surrounded by an effectively infinite amount of water (Ref. 5).

Case 34 - A composite steel/water side reflected stainless steel cylinder filled to a height of $143.0 \mathrm{~cm}$ with $\mathrm{U}(4.98) \mathrm{O}_{2} \mathrm{~F}_{2}$ solution at a $\mathrm{H}^{2.23 \mathrm{U}}$ atomic ratio of 488 . The cylinder inner radius is $16.51 \mathrm{~cm}$ with wall thickness $0.079 \mathrm{~cm}$ and height $243.9 \mathrm{~cm}$. The adjacent reflector consisted of $2.54 \mathrm{~cm}$ of steel surrounded by an effectively infinite amount of water (Ref. 5).

Case 35 - An unreflected stainless steel sphere filled with $\mathrm{U}(4.98) \mathrm{O}_{2} \mathrm{~F}_{2}$ solution at a $\mathrm{H}^{235} \mathrm{U}$ atomic ratio of 490 . The sphere inner radius is $25.3873 \mathrm{~cm}$ with wall thickness $0.0508 \mathrm{~cm}$ (Ref. 5).

Case 36 - An unreflected stainless steel cylinder filled to a height of $01.7 \mathrm{~cm}$ with $\mathrm{U}(4.98) \mathrm{O}_{2} \mathrm{~F}_{2}$ solution at a $\mathrm{H}^{2}{ }^{235} \mathrm{U}$ atomic ratio of 496 . The cylinder inner radius is $19.55 \mathrm{~cm}$ with wall thickness $0.07874 \mathrm{~cm}$ and height $125.09 \mathrm{~cm}$ (Ref. 5).

\subsection{ROCKY FLATS PLANT CRTTCAL EXPERIMENTS}

Case 41 - This is experiment number 1 as described in the report NUREG/CR-1071.6 Fuel for this experiment consisted of $\mathrm{U}(4.46)_{3} \mathrm{O}_{8}$ packed inside aluminum cans at a $\mathrm{H}: \mathrm{U}$ of 0.77 . These cans were then placed in a three dinensional array with plexiglas moderator between cans and a plexiglas reflector surrounding the array. The thickness of the interstitial moderator is approximately $2.5 \mathrm{~cm}$ putting the experiment in the optimum moderated category. Criticality was achieved with an array of 42 fuel cans with critical table separation of $3.1 \mathrm{~mm}$.

Case 42 - This is experiment number 2 as described in the report NUREG/CR-1071. ${ }^{6}$ Fuel for this experiment consisted of $\mathrm{U}(4.46)_{3} \mathrm{O}_{8}$ packed inside alum num cans at a $\mathrm{H}: \mathrm{U}$ of 0.77 . These cans were then placed in a three-dimensional array with a Plr xiglas moderator between cans and a Plexiglas reflector surrounding the array. The thickness of the interstitial moderator is approximately $2.5 \mathrm{~cm}$ putting the experiment in the optimum moderated category. Criticality was achieved with an array of 100 fuel cans with critical table separation of $15.2 \mathrm{~mm}$.

Case 43 - This is experiment number 3 as described in the report NUREG/CR-1071. Fuel for this experiment consisted of $\mathrm{U}(4.46)_{3} \mathrm{O}_{8}$ packed inside aluminum cans at a $\mathrm{H}: \mathrm{U}$ of 0.77 . These cans were then placed in a three-dimensional array with a Plexiglas moderator between cans and a Plexiglas reflector surrounding the array. The thickness of the interstitial moderator is anproximately $1.0 \mathrm{~cm}$ putting the experiment in the undermoderated category. Critieality was achieved with an array of 100 fuel cans with critical table separation of $10.5 \mathrm{~mm}$.

Case 44 - This is the first interstitially moderated experiment described in the report NUREG/CR-1653. ${ }^{7}$ Fuel for this experiment consisted of $U(4.46)_{3} \mathrm{O}_{8}$ packed inside aluminum cans at a $\mathrm{H}: \mathrm{U}$ of 1.25 . These cans were then placed in a three-dimer:sional array with a Plexiglas moderator between cans and a Plexiglas reflector surrounding the array. The thickness of the interstitial moderator is approximately $2.5 \mathrm{~cm}$ putting the experiment in the optimum moderated category. Criticality was achieved with an array of 38 fuel cans with critical table separation of $12.608 \mathrm{~mm}$.

Case $4 \mathrm{~J}-\mathrm{i}: ;$ is the second interstitially moderated experiment described in the repost irUREG/CR-1653.' Fuel for this experiment consisted of $U(4.46)_{3} \mathrm{O}_{8}$ packed irside aluminum caus at a $\mathrm{H}: \mathrm{U}$ of 1.25 . These cans were then placed in a three-dimensional array with a Plexiglas moderator between cans and a Plexiglas reflector surrounding the array. "ihe thickness of the interstitial moderato- is approximately $1.0 \mathrm{~cm}$ putting the experiment in the undermoderated category. Criticality was achieved with an array of 78 fuel cans with critical table separation of $7.98 \mathrm{~mm}$. 
Case 46 - This is the third interstitially moderated experiment desiribed in the report NUREG/CR-1653. ${ }^{7}$ Fuel for this experiment consisted of $U(4.46)_{3} \mathrm{O}_{8}$ packitd ir.side aluminum cans at a $\mathrm{H}: \mathrm{U}$ of 1.25 . These cans were then placed in a three-dinensional array with a Plexiglas moderator between cans and a Plexiglas reflector surrounding the array. The thicknesi of the interstitiai moderator is approximately $1.0 \mathrm{~cm}$ putting tive experiment in the undermoderated category. Criticality was achieved with an array of 80 fuel cans with critical table separation of $15.61 \mathrm{~mm}$.

Case 47 - This is experiment $F$ as described in the report NUREG/CR-2500.8 Fuel for this experiment consisted of $\mathrm{U}(4.46)_{3} \mathrm{O}_{\text {\& }}$ packed inside aluminum cans at a $\mathrm{H}: \mathrm{U}$ of 2.03 . These cans were then placed in a three-cimensional array with a Plexiglas moderator between cans and a Plexiglas reflector surrounding the array. The thickness of the interstitial moderator is approximately $1.0 \mathrm{~cm}$ putting the experiment in the undermoderatsod category. Criticality was acnieved with a. array of $\mathbf{4 8}$ fuel cans with critical table separation of $4.1 \mathrm{~mm}$.

Case 48 - This is experiment $G$ as described in the report NUKEG/CR-2500.8 Fuel for this experiment consisted of $\mathrm{U}(4.40)_{3} \mathrm{O}_{8}$ packed inside aluminum cans at a $\mathrm{H}: \mathrm{IJ}$ of 2.03 . These cans were then placed in a three-dimensiunal array with a Plexiglas moderator between cans and a Plexiglas reflector surroundi:a ike array. The thickness of the interstitial riocierator is approximately $2.5 \mathrm{~cm}$. Futiting the experiment in the optimum moderated category. Criticality was achieved with an array of $\mathbf{3 0}$ fuel cans with critical table separation of $5.7 \mathrm{~mm}$. 


\section{Calculation.lL method}

The experiments considered in this work are modeled with the SCAl E code system using the CSAS25 control module. This routine calculates number densities in a standardized fashion from the given experimental data and then calls a sequence of functional modules to process the data. Resonance parameters for the heavy absorbers used in the calculation are performed by BONAMI and/or NITAWL, with NITAWL converting the data into a working library. ICE next prepares the cross sections for the different mixtures of materials, and then KENO V.a performs the Monte Carlo criticality calculation.

The SCALE input for each calculation was submitted individually to an IBM-3033 computer. Unless otberwise specified, each calculation utilized default values available in SCALE. The experiments reflected with paraffin on top and sides and with Plexiglas on the bottom employed reflector biasing. The KENO V.a code des not have reflector biasing data available for Plexiglas or polyethylene which were employed as reflectors in some of the experiments. Due to the similar hydrogen density of polyethylene and paraffin, parafin biasing data can be safely used in polyethylene reflectors. Plexiglas has a lower hydrogen density than paraffin so some calculations were performed with and without reflector biasing to determine if there was an effect on the results (these results reported in Section 3). 


\section{VALIDATION OF KENO V. AND TWO CROSSSECTION LIBRARIES}

Calculational methods for predicting criticality safety are validated to ensure confidence in the method. In all processes involving fissionable material, specific conditions are required to maintain the safe, $y$ of the operation. The calculational methods available are used to prodict limits for safe operation, thus requiring a high level of confidence in the calculational methods. This report validates the SCALE version of KENO V.a when used with either the 27-group ENDF/B-IV library or the 16-group Hansen-Roach library by means of comparing experimental results with calculated results. Table 3.1 contains calculated $k_{e r r}$ 's and their associated standard deviations (rounded off to three decimal places) for the 37 critical experiments considered in this validation study. For the benefit of future validation studies, Table A.I in Appendix A contains the value of $k_{\text {ert }}$ as given in the computer output.

Included in this section are comparative studies of KENO V.a versus KENO IV, and KENO V.a with defaclt options versus KENO V.a with specific options. An error was detected in the resonance treatment of the Hansen-Roach cross-section library during this study. The crosssection library and code were promptly modified to make them compatible. Tables 4.2, 4.4, and 4.6 contain values calculated before the char.ge was made. All other tables containing 16-group library results are calculated with the new version. A more detailed explanation of the problem is included at the end of the section.

Five experiments were chosen to compare KENO V.a with KENO IV, cases 11, 12, 21, 22, and 26. These calculations were performed using 103 generations at 300 neutrons per generation and reflector biasing was not used in the reflected cases. Table 4.1 shows the results of these calculations when the 27-group ENDF/B-IV cross-section library is used. It is noted that case 22 did not properly converge for the given number of histories. Case 22 shown in Table 4.1 is case 22 with reflector biasing and it is within one standard deviation of the KENO IV resu.t. Table 4.2 shows the results of the same experiments when the 16-group Hansen-Roach library is used. The KENO V.a result and KENO IV result are within two standard deviations for each experiment (most comparisons are within one sigma), thus establishing the mechanics of the KENO V.a code to be in good working order. However, it is noted that the calculated value of $k_{e f f}$ can differ by as much as $3 \%$ according to which cross-section library is used, independent of the version KENO used.

Another item under investigation is the effect of changing the default number of generations and histories per generation while keeping the total number of histories approximately constant. This involves changing the number of generations from 103 to 53 and the number of neutrons per generation from 300 to 600 . Ten experiments at five different $\mathrm{H}^{235} \mathrm{U}$ atom ratios (reflected and unreflected at each $\mathrm{H}^{235} \mathrm{U}$ ) were modeled with this change, and the results are shown in Tables 4.3 and 4.4. The default version $k_{e f r}$ 's and modified version $k_{e f f}$ 's are within two standied deviations for each experiment according to cross-section library. Again, large differences in $k_{\text {eff }}$ exist depending on which cross-section library is used with the Hansen-Roach value being consistently higher.

The KENO V.a code has a reflector biasing option that helps reduce the amount of computer time used in a calculation. To evaluate this option several test cases were run with and without biasing to determine if biasing forced the calculation to diverge from the true solution. Table 4.5 contains the resr:'s of the 27-group calculations, and Table 4.6 contains the results of the Hansen-Roach ca'culations. The results with and without reflector biasing are within two standard deviations (all but one is within one standard deviation) for each experiment, thus giving a high level confidence in tiis option. Again, it is noted that there is a significant difference (as much as $3 \%)$ in the value of $k_{e f r}$ according to which cross-section library is used.

The large differences in $k_{e f i}$ 's according to cross-section library were further investigated in an effort to explain why the values calculated by Hansen-Roach data were consistently higher than those calculated by ENDF/B-IV data. It was suggested that the value of sigma $P$ (also known 
Table 4.I Comparison of KENO V.a with KENO IV using 27-group library

\begin{tabular}{ccccccc}
\hline $\begin{array}{c}\text { Case } \\
\text { no. }\end{array}$ & Reflected & KENO V.a & Std dev & KENO IV & Std dev & $\begin{array}{c}\text { Within } \\
\text { ore sigma }\end{array}$ \\
\hline 11 & YES & 0.994 & 0.003 & 1.005 & 0.004 & NO \\
12 & NO & 1.009 & 0.004 & 1.005 & 0.004 & YES \\
21 & YES & 1.016 & 0.004 & 1.010 & 0.004 & YES \\
22 & YES & 1.024 & 0.004 & 1.019 & 0.004 & NO \\
$22^{2}$ & YES & 1.015 & 0.004 & & & YES \\
26 & NO & 1.017 & 0.004 & 1.013 & 0.004 & YES \\
\hline
\end{tabular}

aptimum moderated experiment.

Table 4.2 Comparison of KENO V.a with KENO IV using 16-group library

\begin{tabular}{ccccccc}
\hline $\begin{array}{c}\text { Case } \\
\text { no. }\end{array}$ & Reflected & KENO V.a & Std dev & KENO IV & Std dev & $\begin{array}{c}\text { Within } \\
\text { one sigma }\end{array}$ \\
\hline 11 & YES & 1.033 & 0.003 & 1.033 & 0.004 & YES \\
12 & NO & 1.024 & 0.004 & 1.031 & 0.004 & YES \\
21 & YES & 1.049 & 0.004 & 1.040 & 0.004 & YES \\
22 & YES & 1.040 & 0.004 & 1.034 & 0.004 & YES \\
26 & NO & 1.040 & 0.005 & 1.035 & 0.004 & YES \\
\hline
\end{tabular}

Table 4.3 KENO $V_{\text {.a }}$ with default histories and modified histories using the 27 -group library

\begin{tabular}{cccccc}
\hline $\begin{array}{c}\text { Case } \\
\text { no. }\end{array}$ & $\begin{array}{c}\text { Default } \\
\text { histories }\end{array}$ & Std dev & $\begin{array}{c}\text { Modified } \\
\text { histories }\end{array}$ & Std dev & $\begin{array}{c}\text { Within } \\
\text { one sigma }\end{array}$ \\
\hline 11 & 0.998 & 0.004 & 1.003 & 0.004 & YES \\
12 & 1.009 & 0.004 & 1.002 & 0.004 & YES \\
13 & 0.999 & 0.004 & 1.000 & 0.004 & YES \\
14 & 1.000 & 0.004 & 1.003 & 0.004 & YES \\
17 & 0.996 & 0.003 & 1.003 & 0.003 & NO \\
18 & 1.000 & 0.003 & 1.004 & 0.003 & YES \\
19 & 0.992 & 0.002 & 0.981 & 0.003 & NO \\
20 & 0.991 & 0.003 & 0.984 & 0.003 & YES \\
25 & 1.014 & 0.005 & 1.009 & 0.004 & YES \\
26 & 1.017 & 0.004 & 1.012 & 0.004 & YES \\
\hline
\end{tabular}


Tabte 4.4 KENO V.a with default histories and modified histories using tine 16-group library

\begin{tabular}{cccccc}
\hline $\begin{array}{c}\text { Case } \\
\text { mo. }\end{array}$ & $\begin{array}{c}\text { Default } \\
\text { histories }\end{array}$ & Std dev & $\begin{array}{c}\text { Modified } \\
\text { histories }\end{array}$ & Std dev & $\begin{array}{c}\text { Within } \\
\text { one sigma }\end{array}$ \\
\hline 11 & 1.028 & 0.004 & 1.030 & 0.004 & YES \\
12 & 1.024 & 0.004 & 1.023 & 0.004 & YES \\
13 & 1.031 & 0.004 & 1.018 & 0.004 & NO \\
14 & 1.024 & 0.004 & 1.012 & 0.003 & NO \\
17 & 1.018 & 0.004 & 1.004 & 0.003 & NO \\
18 & 1.008 & 0.003 & 1.012 & 0.002 & YES \\
19 & 1.003 & 0.003 & 1.013 & 0.003 & NO \\
20 & 1.002 & 0.002 & 1.002 & 0.003 & YES \\
25 & 1.037 & 0.005 & 1.042 & 0.004 & YES \\
26 & 1.040 & 0.005 & 1.033 & 0.004 & YES \\
\hline
\end{tabular}

Table 4.5 Comparison of reflector biasing using 27-group library

\begin{tabular}{cccccc}
$\begin{array}{c}\text { Case } \\
\text { no. }\end{array}$ & $\begin{array}{c}\text { Wi:l. } \\
\text { biasing }\end{array}$ & Std dev & $\begin{array}{c}\text { Without } \\
\text { biasing }\end{array}$ & Std dev & $\begin{array}{c}\text { Within } \\
\text { one sigma }\end{array}$ \\
\hline 11 & 0.998 & 0.004 & 0.994 & 0.003 & YES \\
13 & 0.999 & 0.004 & 1.004 & 0.003 & YES \\
21 & 1.016 & 0.004 & 1.017 & 0.004 & YES \\
22 & 1.015 & 0.004 & 1.024 & 0.004 & NO \\
24 & 1.014 & 0.005 & 1.011 & 0.004 & YES \\
\hline
\end{tabular}

Table 4.6 Comparison of reflector biasing using 27-group library

\begin{tabular}{cccccc}
$\begin{array}{c}\text { Case } \\
\text { no. }\end{array}$ & $\begin{array}{c}\text { With } \\
\text { biasing }\end{array}$ & Std dev & $\begin{array}{c}\text { Without } \\
\text { biasing }\end{array}$ & Std dev & $\begin{array}{c}\text { Within } \\
\text { one sigma }\end{array}$ \\
\hline 11 & 1.028 & 0.004 & 1.033 & 0.003 & YES \\
13 & 1.039 & 0.004 & 1.027 & 0.003 & YES \\
21 & 1.0496 & 0.004 & 1.042 & 0004 & YES \\
22 & 1.0415 & 0.005 & 1.041 & 0.004 & YES \\
24 & 1.036 & 0.005 & 1.038 & 0.004 & YES \\
\hline
\end{tabular}


as sigma $m_{e f f}$ ) calculated by SCALE should be compared with the ralues of sigma $P$ used in Ref. 5. The results of this comparison are listed in Table 4.7, which indicates that, rithen using the Hansen-Roach library, the sigma $P$ value is inderestimated by about $20 \%$. This in turn caused the self-shielding calculation for ${ }^{238} \mathrm{U}$ to underestimate the capture cross section, thus leading to a higher value of $k_{\text {effr }}$. The problem was traced to a routine in BONAMI that calculated sigma P. This calculation required the total cross section but instead it was using a transport-corrected cross section from the Hansen-Roach cross-section librafy. This inconsistency was corrected and resulted in Hansen-Roach $k_{\text {efr's }}$ much closer to the ENDF/B-IV kefi's. Table 4.8 contains results sf the first 29 experiments for both the old version and the new version. 
Table 4.7 Values of sigma $P$

\begin{tabular}{ccccc}
\hline $\begin{array}{c}\text { Case } \\
\text { no. }\end{array}$ & $\begin{array}{c}\text { Value in } \\
\text { ref. } 5\end{array}$ & $\begin{array}{c}\text { SCALE used } \\
\text { with 27 gp. }\end{array}$ & $\begin{array}{c}\text { SCALE used } \\
\text { with old 16 gp. }\end{array}$ & $\begin{array}{c}\text { SCALE used } \\
\text { with new 16 gp. }\end{array}$ \\
\hline 04 & 160 & 160.8 & 128.3 & 165.7 \\
05 & 160 & 160.8 & 128.3 & 165.7 \\
06 & 160 & $16 C .8$ & 128.3 & 165.7 \\
11 & 120 & 114.7 & 93.8 & 119.8 \\
12 & 120 & 114.7 & 93.8 & 119.8 \\
13 & 160 & 160.8 & 128.7 & 166.2 \\
14 & 160 & 160.8 & 128.7 & 166.2 \\
15 & 220 & 213.5 & 168.5 & 219.0 \\
16 & 260 & 255.5 & 199.2 & 261.2 \\
17 & 330 & 310.6 & 242.0 & 316.5 \\
18 & 330 & 310.6 & 242.0 & 316.5 \\
19 & 400 & 479.1 & 369.4 & 485.5 \\
20 & 400 & 479.1 & 369.4 & 485.5 \\
21 & 120 & 118.2 & 96.2 & 124.0 \\
22 & 120 & 118.2 & 96.2 & 124.0 \\
23 & 120 & 118.2 & 96.2 & 124.0 \\
24 & 120 & 118.2 & 96.2 & 124.0 \\
25 & 120 & 118.2 & 96.2 & 124.0 \\
26 & 120 & 118.2 & 96.2 & 124.0 \\
27 & 120 & 118.2 & 96.2 & 124.0 \\
28 & 120 & 118.2 & 96.2 & 124.0 \\
29 & 220 & 220.0 & 174.2 & 226.3 \\
30 & 220 & 220.0 & 174.2 & 226.3 \\
31 & 220 & 220.0 & 174.2 & 226.3 \\
32 & 220 & 220.0 & 174.2 & 226.3 \\
33 & 600 & 602.3 & 464.9 & 609.1 \\
34 & 600 & 602.0 & 464.9 & 609.1 \\
35 & 600 & 602.2 & 465.0 & 609.2 \\
36 & 600 & 602.4 & 464.9 & 609.1 \\
\hline & & & &
\end{tabular}


Table 4.8 Comparison of results from SCALE after revision

\begin{tabular}{ccccc}
\hline & \multicolumn{4}{c}{ k-effective \pm 1 sigma } \\
\cline { 2 - 5 } Exp. & \multicolumn{2}{c}{ Old :ersion } & \multicolumn{2}{c}{ New version } \\
\hline 04 & $1.02051 \pm$ & 0.00318 & $0.99647 \pm$ & 0.00337 \\
05 & 1.03049 & 0.00318 & 0.99776 & 0.00326 \\
06 & 1.02484 & 0.00329 & 1.00764 & 0.00311 \\
11 & 1.02801 & 0.00399 & 0.99587 & 0.00365 \\
12 & 1.02386 & 0.00371 & 0.99744 & 0.00327 \\
13 & 1.03082 & 0.00446 & 1.00337 & 0.00335 \\
14 & 1.02370 & 0.00368 & 0.99609 & 0.00395 \\
15 & 1.01288 & 0.00363 & 1.00108 & 0.00378 \\
16 & 1.01583 & 0.00341 & 0.99737 & 0.00325 \\
17 & 1.01757 & 0.00369 & 0.98408 & 0.00342 \\
18 & 1.00872 & 0.00309 & 0.98871 & 0.00361 \\
19 & 1.00263 & 0.00276 & 0.99527 & 0.00292 \\
20 & 1.00172 & 0.00239 & 0.98804 & 0.00273 \\
21 & 1.04861 & 0.00437 & 1.01363 & 0.00401 \\
22 & 1.04053 & 0.00459 & 1.01660 & 0.00445 \\
23 & 1.03795 & 0.00380 & 1.00874 & 0.00485 \\
24 & 1.03600 & 0.00478 & 1.01190 & 0.00479 \\
25 & 1.03692 & 0.00465 & 1.00980 & 0.00498 \\
26 & .03993 & 0.00492 & 1.00565 & 0.00397 \\
27 & 1.04139 & 0.10448 & 1.01929 & 0.00407 \\
28 & 1.02522 & 0.60447 & 1.00860 & 0.00411 \\
29 & 1.02674 & 0.00513 & 0.99487 & 0.00462 \\
30 & 1.01798 & 0.00578 & 0.99257 & 0.00382 \\
31 & 1.02314 & 0.00407 & 1.00132 & 0.00450 \\
32 & 1.01886 & 0.00447 & 0.99154 & 0.00420 \\
33 & 0.99709 & 0.00404 & 1.00028 & 0.00374 \\
34 & 1.00070 & 0.00402 & 299565 & 0.00413 \\
35 & 0.99341 & 0.00457 & 0.98574 & 0.00415 \\
36 & 0.99651 & 0.00478 & 0.98733 & 0.00416 \\
\hline & & & &
\end{tabular}




\section{TESTS FOR TRENDS AND BIASES}

In this study two cifferent cross-section libraries were used to obtain corresponding values of $k_{\text {eff }}$ for each experiment. These calculated values differ stightly from the reported experimental values of $\mathrm{k}_{\mathrm{f}}$ which could be caused in part by the statistical nature of the Monte Carlo solution. It is of interest to ascertain if a trend exists in the solution which is related is some quantity associated with the experiments. If such trends exist and can be defined, then some departure from the expected value of $k_{\text {ef }}$ could be predicted based on information frotat the experiment and crosssection library used.

Some of the quantities investigated include $\mathrm{H}^{235} \mathrm{U}$ atom ratio, earichment, $\mathrm{H}:{ }^{23 n} \mathrm{U}$ ratio, and a calculated parameter, average energy of a neutron causing frssion weighted by energy group number (AE). Some of the parameters considered are not independent; that is for a given $\mathrm{H}^{2}{ }^{23} \mathrm{U}$ ratio and enrichment, the $H_{-}^{230} \mathrm{U}$ ratio can be calculated. Also there is a relation between average energy and the $\mathrm{H}_{-}^{235} \mathrm{U}$ ratio which is not 1 nown. This implies that separate models must be developed for $\mathrm{H}:{ }^{23} \mathrm{U}$ and average exergy, and also a model cannot contain the three parameters H: ${ }^{235} \mathrm{U}, \mathrm{H}:{ }^{238} \mathrm{U}$, and earichment. Linear relationships between library) and experimental parameters can be determined. if any exist, from the data in Table 5.1. Tests for trends and biases are performed only on the homogeneous experiments thus excluding experiments 41 through 48 because of the interstitia! moderation.

The statistical analysis of the experimental parameter effects on $\mathbf{k}_{\mathrm{d} f}$ consisted of first finding the simple correlation coeffrisients (Pearson Product Moment) between the $k_{e-f}$ 's (according to crosssection library) and each of the experimental parameters. The sorrelation coefficient is defined only on the nterval -1 to +1 , where +1 implies perfect positive correlation and -1 is perfect negative correlation. Each correlation coefficient has associated with it a significance level which is a measure of the uncertainty in the correlation coefficient. Table 5.2 contains the values of the correlation coefticients and their significance level for selected parameters.

When $k_{\text {efl's }}$ were calculated ising the Hansen-Roach cross-section library results were correlated with average energy and were found to have a large corr ilation coefticient $(-0.8)$ and a corresponding low significance level $(0.0001)$. When the Hansen-Roach $k_{e r i}$ 's were correlated with $H_{:}{ }^{235} \mathrm{U}$ the correlation coefficient was not as high as the one for average energy. A similar analysis was performed using the keri's calculated using the 27-group library and it was found that the correlation coefficients were nearly identical for average energy and $\mathrm{H}^{.235} \mathrm{U}$. It was found that for both crosssection libraries the $H^{: 238} \mathrm{U}$ ratio was not as highly correlated as was the $\mathrm{H}^{2{ }^{235}} \mathrm{U}$ ratio, and since these ratios are coupled by hydrogen, the $\mathrm{H}^{2}{ }^{238} \mathrm{U}$ ratio was dropped from the investigation.

The above results indicate that there are three important models that can be developed to describe the effects of the parameters on the resulting $k_{\text {ent }}$. There would be one model for HansenRoach results that would show $k_{e r t}$ as a function of average energy and two separate models for 27-group results, the first being a function of average energy and the second being a function of H: ${ }^{235} \mathrm{U}$. The results of this study are presented in Section 6 . 
Table 5.1 Experiment paremeters considered in trend analysis

\begin{tabular}{|c|c|c|c|c|c|}
\hline $\begin{array}{l}\text { Case } \\
\text { no. }\end{array}$ & $\underset{200}{H:}$ & $\begin{array}{l}\text { H: } \\
{ }^{235} \mathrm{U}\end{array}$ & $\begin{array}{l}\text { go Wt } \\
{ }^{23 S} \mathbf{L}^{*}\end{array}$ & $\underset{\text { 27-gronp }}{A E}$ & $\underset{\text { 16-group }}{A E}$ \\
\hline 04 & 6.1 & 421.8 & 1.4 & 23.13 & 14.82 \\
\hline 05 & 6.1 & $\$ 21.8$ & 1.4 & 23.11 & 14.81 \\
\hline 06 & 6.1 & 421.8 & 1.4 & 23.12 & 14.83 \\
\hline 11 & 4.0 & 195.2 & 2.0 & 22.33 & 14.44 \\
\hline 12 & 4.0 & 195.2 & 20 & 22.07 & 14.28 \\
\hline 13 & 6.1 & 293.9 & 2.0 & 23.08 & $! 4.84$ \\
\hline 14 & 6.1 & 293.9 & 20 & 22.87 & 14.73 \\
\hline 15 & 8.4 & 406.3 & 20 & 23.55 & 15.08 \\
\hline 16 & 10.3 & 495.9 & 2.0 & 23.80 & 15.20 \\
\hline 17 & 12.7 & 613.6 & 2.0 & 24.03 & 15.31 \\
\hline 18 & 12.7 & 613.6 & 2.0 & 23.93 & 15.26 \\
\hline 19 & 20.1 & 971.7 & 2.0 & 24.39 & 15.50 \\
\hline 20 & 20.1 & 971.7 & 2.0 & 24.36 & 15.49 \\
\hline 21 & 4.2 & 133.4 & 3.0 & 22.04 & 14.36 \\
\hline 22 & 4.2 & 133.4 & 3.0 & 22.07 & 14.36 \\
\hline 23 & 4.2 & 133.4 & 3.0 & 22.09 & 14.36 \\
\hline 24 & 4.2 & 133.4 & 3.0 & 22.05 & 14.38 \\
\hline 25 & 4.2 & 133.4 & 3.0 & 22.07 & 14.35 \\
\hline 26 & 4.2 & 133.4 & 3.0 & 21.59 & 14.10 \\
\hline 27 & 4.2 & 133.4 & 3.0 & 21.62 & 14.12 \\
\hline 28 & 4.2 & 133.4 & 3.0 & 21.60 & 14.10 \\
\hline 29 & 8.7 & 276.9 & 3.0 & 23.42 & 15.04 \\
\hline 30 & 8.7 & 276.9 & 3.0 & 23.17 & 14.90 \\
\hline 31 & 8.7 & 276.9 & 3.0 & 23.20 & 14.90 \\
\hline 32 & 8.7 & 276.9 & 3.0 & 23.16 & 14.90 \\
\hline 33 & 25.9 & 488.0 & 4.98 & 24.15 & 15.43 \\
\hline 34 & 25.9 & 488.0 & 4.98 & 24.17 & 15.44 \\
\hline 35 & 26.0 & 490.0 & 4.98 & 24.18 & 15.43 \\
\hline 36 & 26.3 & 496.0 & 4.98 & 24.18 & 15.43 \\
\hline
\end{tabular}

Table 5.2 Correlation coefficients and significance levels obtained by comparing results from 27-group and 16-group calculations with certain experiment parameters

\begin{tabular}{ccc}
\hline & \multicolumn{2}{c}{ Correlation coefficient (significance levei) } \\
\cline { 2 - 3 } parameter & 27-group library & 16-group library \\
\hline$A E$ & $-0.62(0.0004)$ & $-0.76(0.0001)$ \\
$H:{ }^{235} U$ & $-0.74(0.0001)$ & $-0.66(0.0001)$ \\
$H:{ }^{238} U$ & $-0.42(0.02)$ & $-0.60(0.0005)$ \\
Enrichment & $0.31(0.08)$ & $-0.05(0.8)$ \\
\hline
\end{tabular}




\section{RESULTS AND CONCLUSIONS}

The results obtained using KENO V.a and two ctoss-section libraries tu analyze 37 individual critical experiments are presented in Table 3.1. Results from the tests for :rends and biases indicate that there is a relationship between the experimental parameters and the cross-section library used. Linear models were developed to describe the relation between $k_{\text {efr }}$ (according to cross-section library) and the independent variables considereci. These simple linear models were estimated from the results of the 29 homogeneous experiments in Ref. 5. In addition, lower tolerance limits were approximated for the distribution of $k_{\text {eff }}$ values around the model on a prescribed closed interval of the independent variable. The tolerance limits are such that one can say that $99.9 \%$ of the distribution of $k_{e n t}$ values, for a given value of the independent varizole, will lie above the tolerance limits with 95\% confidence. A discussion of the tolerance limits is included in Appendix E.

When the 16-group Hansen-Rcach library is used in the calculation of $k_{e f r}$, there is a significant change in the value of $k_{\text {efr }}$ from the experimental value depending on the average energy of a neutron causing fission (AE). This trend can te described by the following linear model:

1) $k_{\text {eft }}=1.2267-1.5297 \mathrm{E}-2^{*}(\mathrm{AE})$.

This model accounts for $59 \%$ of the variation (i.e., corrected total sum of squares) for the 29 observations. Figuie 6.1 illustrates how the value of $k_{\text {efr }}$ varies over the range of $\mathrm{AE}$ and includes the lower tolerance limit for $99.9 \%$ of the population with a $95 \%$ confidence level. The tolerance limit is defined only on the closed interval of values of AE ranging from 14.I to I5.5 (see Appendix E).

When the 27-group ENDF/B-IV library is used in the calculation of $k_{e r r}$, there is a significant deviation from the reported critical value of $k_{\text {eff }}$ for some of the cases. There are two separate trends associated with these deviations, one of which can be described by the following linear model:

2) $k_{\text {eff }}=1.0098+2.2407 \mathrm{E}-3 *$ (enrichment $)-2.9875 \mathrm{E}-5^{*}\left(\mathrm{H}^{23 !} \mathrm{U}\right)$.

This model accounis for $61 \%$ of the variation for the 29 observations. The other trend can be described by the follcwing model:

3) $k_{e f f}=1.1710+4.1472 E-3 *($ enrichment $)-7.6653 E-3 *(A E)$.

This model accounts for 59\% of the variation for the 29 observations. Both of the linear models developed for the 27 -group library contain two variables making the resulting plots of $k_{\text {efl }}$ and their associated tolerance limits extremely difficult to interpret. In order to reduce the confusion, both of the above stated models and their tolerance limits are shown at specific values of enrichment. Equation 2 and its associated tolerance limits are shown in Figs. 6.2-6.5 at enrichment values of 1.4, 2.0, 3.0, and 4.98, respectively. Similarly, Equation 3 is shown in Figs. 6.6-6.9. The tolerance limits for Equation 2 are defined only on the interval of AE values ranging from 21.5 to 22.5 and the tolerance limits for Equation 3 are defined only on the interval of $\mathrm{H}^{.235} \mathrm{U}$ values ranging from 133 to 975.

In conclusion, the results of this work indicate that trends in $k_{\text {eff }}$ obtained using KENO V.a and the 16-group Hansen-Roach library can be generally described a linear model for the validated range of AE. Similarly, when using KENO V.a with the 27-group ENDF/B-IV library, trends in $k_{\text {eff }}$ can be generally described by two independent linear models dependent on the validated ranges of $\mathrm{H}:{ }^{235} \mathrm{U}$ ratio, $\mathrm{AE}$, and enrichment. The mean value of $k_{\text {eff }}$ using the Hansen-Roach library is 0.9997 with standard deviation 0.0094 , while the mean value using the 27-group library is 1.0053 with standard deviation 0.0096 . Based on the results of this work for homogeneous UF systems, a safe upper limit for predicting criticality would be $k_{e f f}+2 \sigma$ below the prescribed lower tolerance limit. Overall, hoth cross-section libraries give good results when used with KENO V.a in the SCALE code system. 


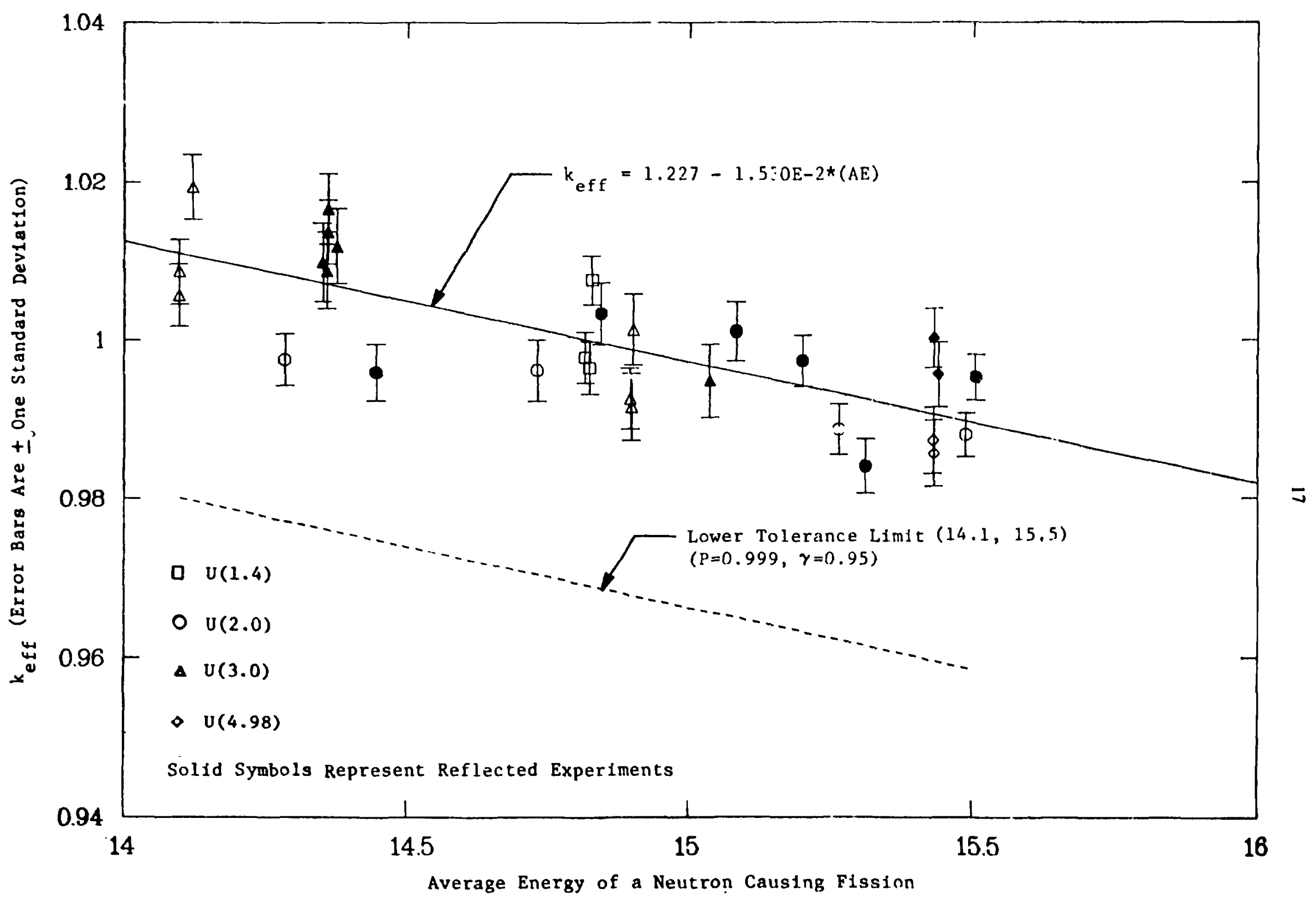

Fig. 6.1 $k_{e f l}$ (16-group) versus AE, linear model and lower tolerance limit 




Fig. 6.2 $k_{\text {eif }}$ (27-group) versus $\mathrm{H}:{ }^{235} \mathrm{U}$ for $\mathrm{U}(1,4)$, linear model and lower tolerance limit 


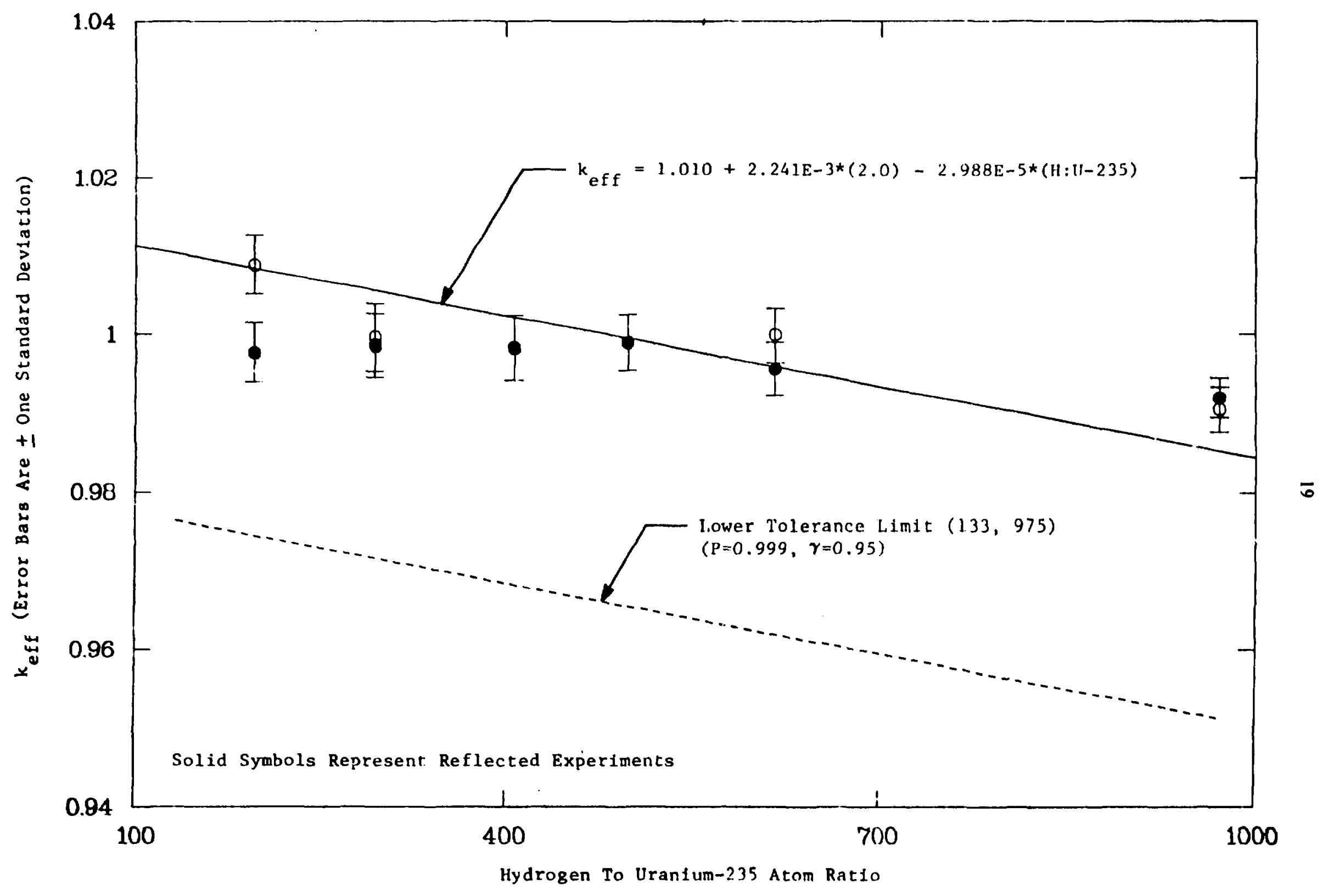

Fig. 6.3 $k_{\text {erf }}$ (27-group) versus $H^{2}: 23 \mathrm{U}$ for $U(2.0)$, linear model and lower tolerance limit 


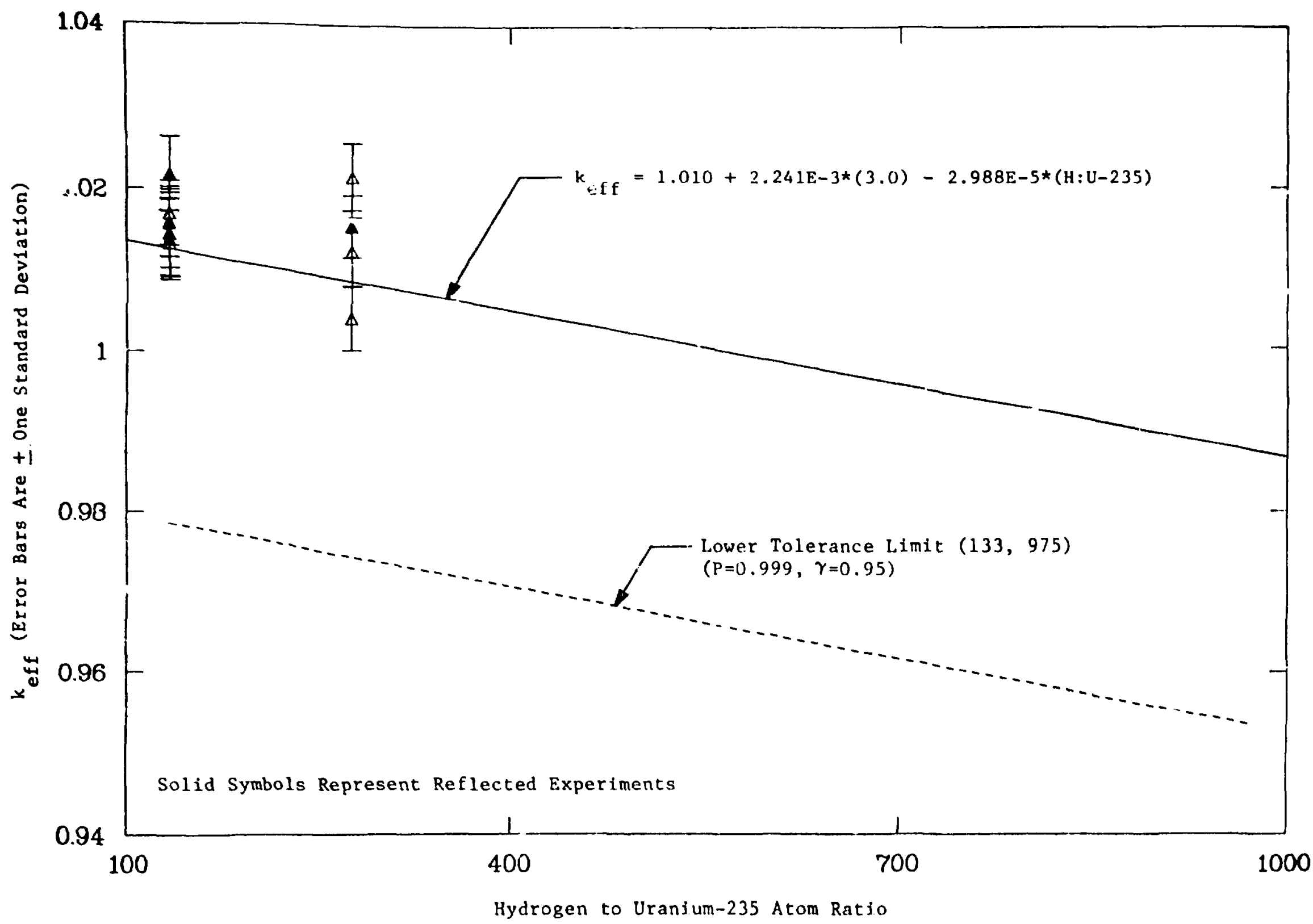

Fig. $6.4 k_{\text {eff }}$ (27-group) versus $H^{235} U$ for $U(3.0)$, linear model and lower tolerance limit 


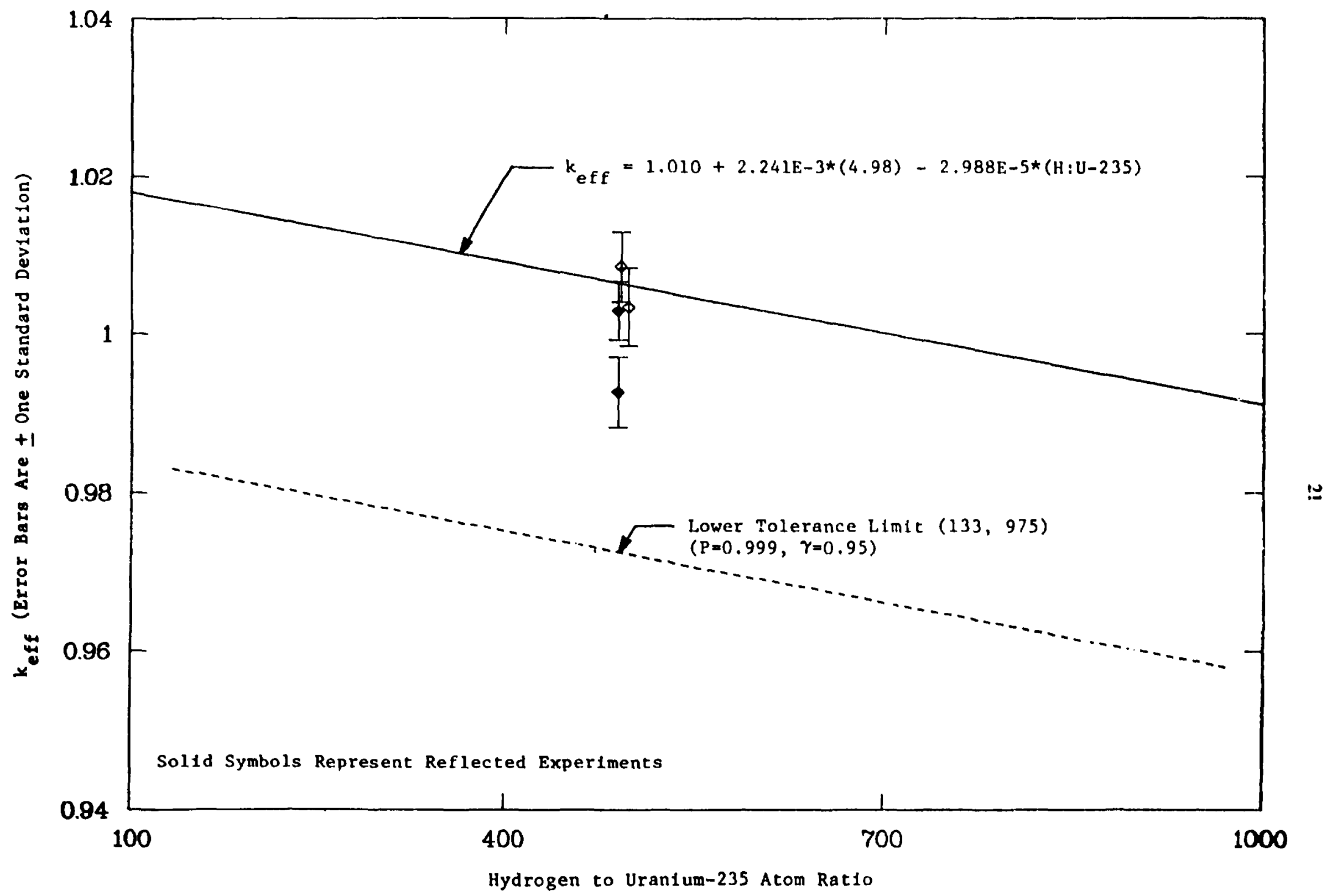

Fig. 6.5 $k_{e r}$ (27-gruup) versus $\mathrm{H}_{:}^{235} \mathrm{U}$ for $\mathrm{U}(4.98)$, linear model and lower tolerance limit 


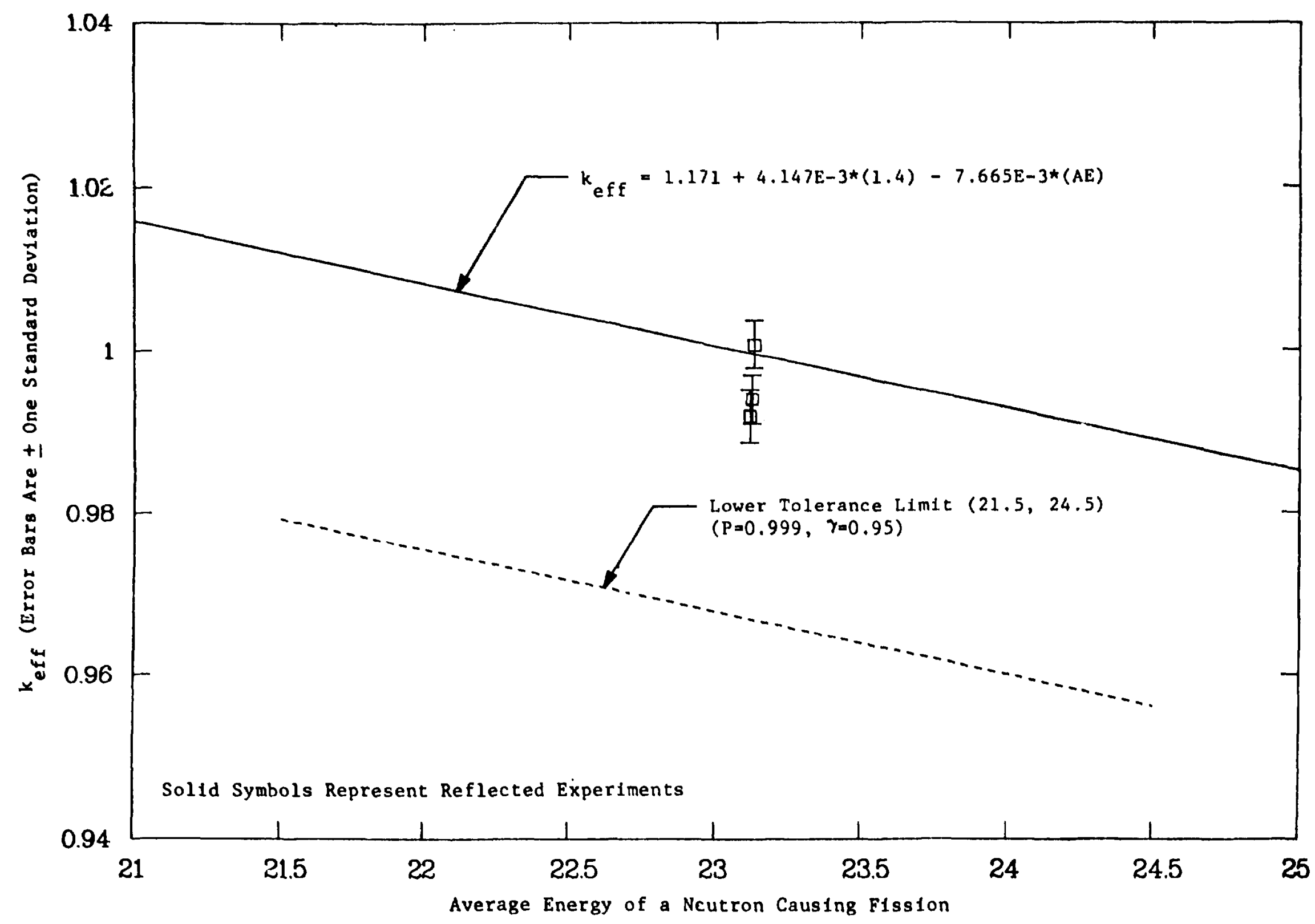

Fig. $6.6 k_{\text {eff }}$ (27-group) versis AE for $U(1.4)$, linear model and lower tolerance limit 


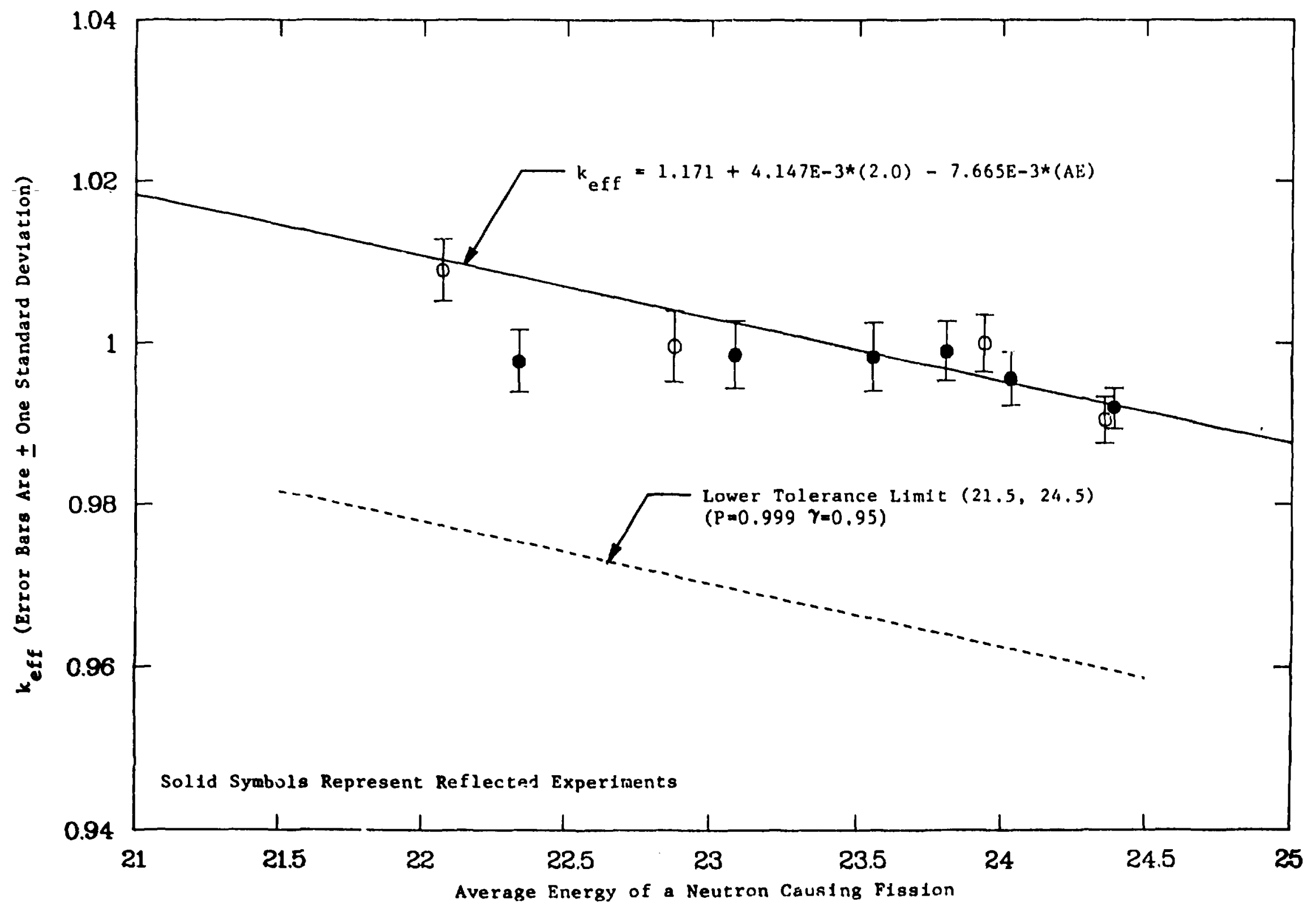

Fig. 6.7 $k_{\text {off }}$ (27-group) versus AE for $U(2.0)$, linear model and lower tolerance limit 


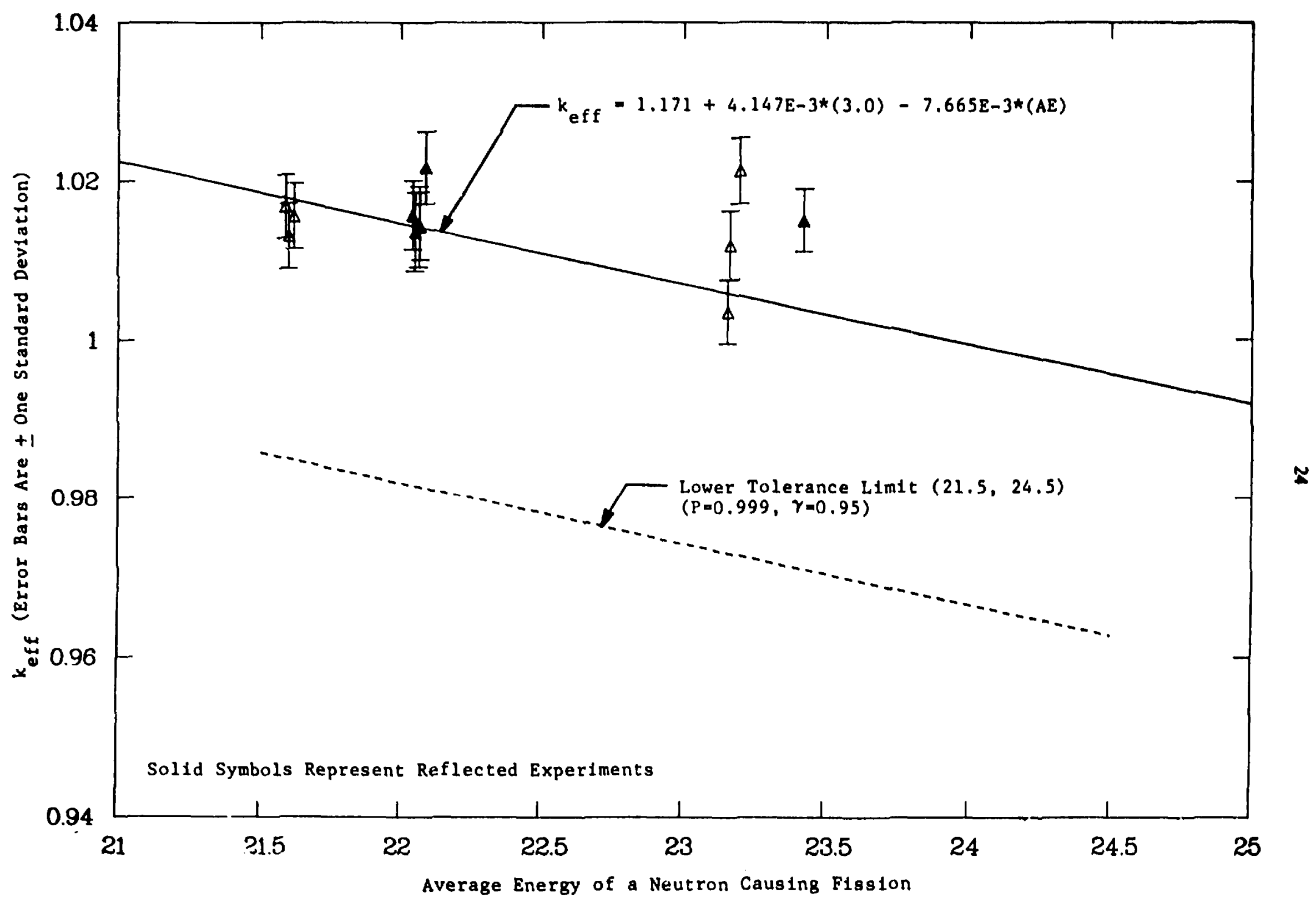

Fig. 6.8 $k_{\text {efr }}$ (27-group) versus AE for $U(3.0)$, linear model and lower tolerance limit 


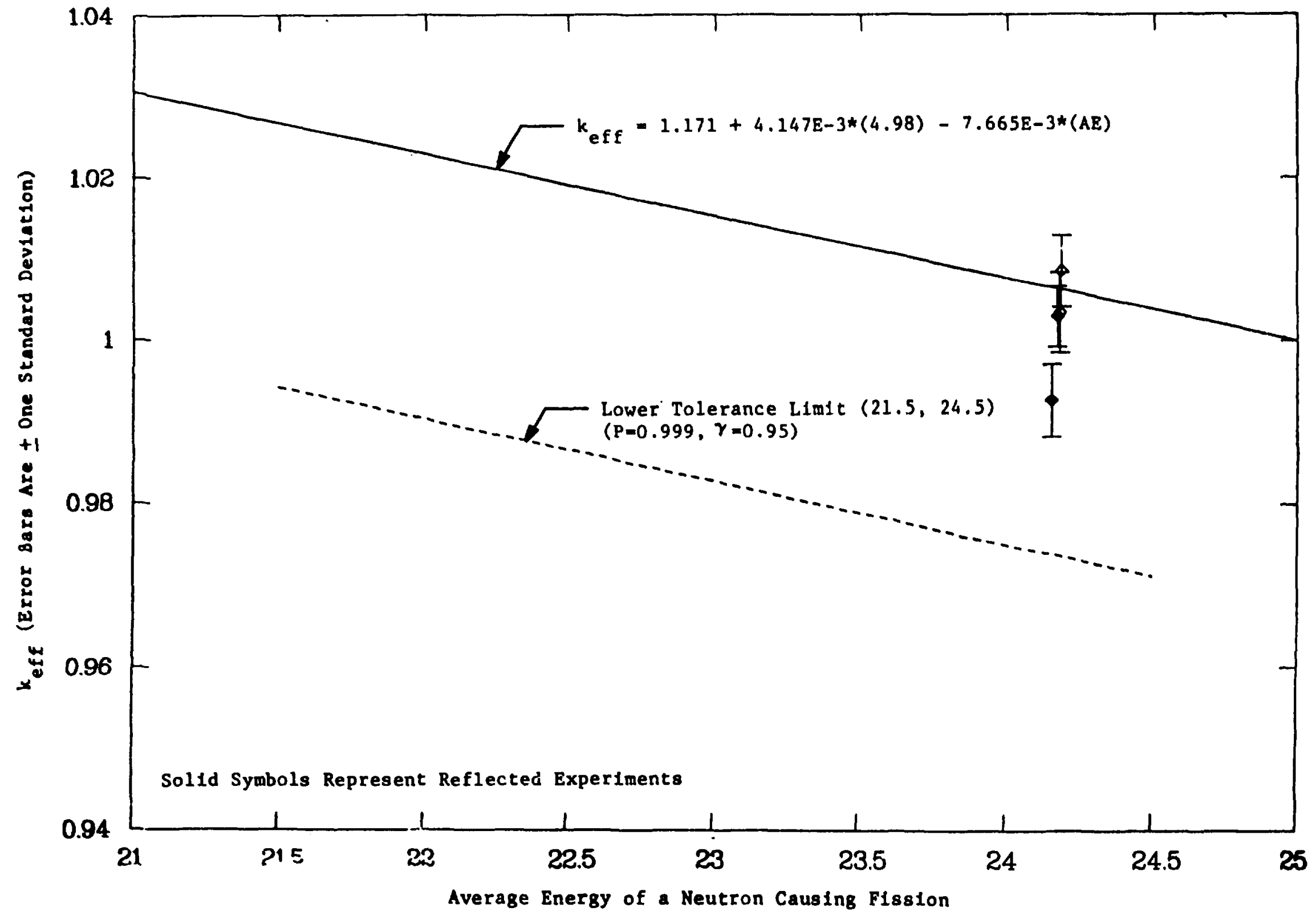

Fig. 6.9 $k_{\text {ent }}$ (27-group) versus AE for U(4.98), linear model and lower tolerance limit 


\section{LST OF REFERENCES}

1. C. V. Parts, Ed., SCALE: A Modular Cade System for Performing Standardized Computer Analysis for Licensing Evaluation," NUREG/CR-0200, ORNL/NUREG/CSD-2 (1980).

2. L. M. Petrie and N. F. Landers, "KENO V.a, An Improved Monte Cario Criticality Program with Supergrouping." NUREG/CR-0200, Volume 2, Section F11, ORNL/N:JREG/CSD-2/VI/R2 (1984).

3. L. M. Petrie and N. F. Landers, "KENO IV/S, An Improved Monte Carlo Criticality Program," NUREG/CR-0200, Volume 2, Section F5, ORNL/NUREG/CSD-2/V2 (1981).

4. American National Standard for Validation of Calculational Method for Nuclear Criticality Safety," ANSI/ANS-8.11-1975, American Nuclear Society, Lagrange Park, Illinois (1975).

5. G. R. Handley and C. M. Hopper, 'Validation of the KENO Code for Nuclear Criticality Safety Calcl lations of Moderated, Low-Enriched Uranium Systems," Y-1948 (1974).

6. R. E. Rothe et al., "Critical Experiments with Interstitially Moderated Arrays of Low-Enriched Uranium Oxide," NUREG/CR-1071 (1980).

7. R. E. Rothe et al., "Critical Experiments on Low-Enriched Uranium Systems with $H / U=$ 1.25," NUREG/CR-1653 (1980).

8. R.E. Rothe et al., "Critical Experiments on Low-Enriched Uranium Oxide Systems with H/U = 2.03," NUREG/CR-2500 (1982).

9. D. K. Trubey and H. T. Hendrickson, "A Review of Multigroup Nuclear Cross Section Processing Proceedings of a Seminar-Workshop, Oak Ridge, Tennessee, March 14-16, 1978," ORNL/RSIC-4I (1981).

10. G. E. Hansen and W. H. Roach, Six and Sixteen Group Cross Sections For Fast and Intermediate Critical Systems," LAMS-2543 (1961).

11. N. L. Johnson, Ed., Tolerance Interval in Regression," Query, Technometrics, 10, 207-09 (1968).

12. "SAS Users' Guide: Statistics, 1982 edition," p. 584, SAS Institute, Inc., Cary, NC (1982).

13. D. C. Bowden and F. A. Graybill, "Confidence Bands of Uniform and Proportional Width for Linear Models," American Statistical Association Journal 61, $182-98$ (1966).

14. G. Tuck and I. Oh, "Benchmark Critical Experiments on Low-Enriched Uranium Oxide Systems With $\mathrm{H} / \mathrm{U}=0.77, "$ NUREG/CR-0674 (1979). 
APPENDIXES 


\section{APPENMIX A}

\section{DXSCRIPTION OF SCALE CODE SYSTEM}

A computational system called SCALE has been developed to provide a standard analysis tool for use by the NRC seaff and licensees :- evaluating nuclear fuel facility and package design. The SCALE system consists of several individual programs running in sequence which perform criticality, shickding. and/or beat transfer calculations with a minimum of user-required input. A detailed description of the entire SCALE code system is provided in Ref. I.

The SCALE system employs automated analytic sequences (control modules) to perform the necessary data processing (cross-section preparation) and manipulation of well-established computer codes (functional modules) required by the calculation. The application of KENO Y.a in SCALE requires the CSAS25 (Criticality Safety Analysis Sequence Number 25) control module to the calleci. CSAS25 first reads input data and then calls BONAMI and/or NITAWL to process the cross-section data; next the information is passed to ICE where the cross sections are mixed for the designated materials, and then the criticality calculation is performed by KENO V.a.

KENO V.a is a multigroup Monte Carlo criticality program used to calculate the $k_{\text {en }}$ of a three-dimensional system. Special features include simplified data input, supergrouping of energydependent data, the ability of specify ozigins for spherical and cylindrical geometry regions, a $P_{a}$ scattering treatment, extended use of differential albedo reflection, and an improved restart capability. The most noted improvement in KENO geometry is the addition of the "array of arrays" and holes" capabilities. The array of arrays option allows the construction of arrays from other arrays. The depth of nesting is limited only by computer space restrictions. This option greatly simplifies the setup for arrays involving different units at different spacing. The hole option allows placing a unit of an array at any desired location within a geometry region. The emplaced unit or array cannot intersect any geometry region and must be wholly contained within a region. As many holes as will snugly fit without intersecting can be placed in a region. This option is especially useful for describing shipping casks and reflectors that have gaps or other geometrical features. Any number of holes can be described in a problem and holes can be nested to any depth.

Cross-section libraries used in this report include the 27-energy-group EIDF/B-IV and the I6-energy-group Hansen-Roach library. The data for the 27-group ENDF/B-IV library were collapsed from the Evaluated Nuclear Data File/B-Version IV9 (ENDF/B-IV). This broad group library was developed specifically for criticality analysis of a wide variety of thermal systems and has undergone extensive evaluation. The Hansen-Roach library is based on the original Lns Alamos report by Hansen and Roach ${ }^{10}$ and was developed primarily for the analysis of fast systems. Data for a few nuclides missing in the original library were generated by collapsing the 218-group ENDF/B-IV to I6 group. 


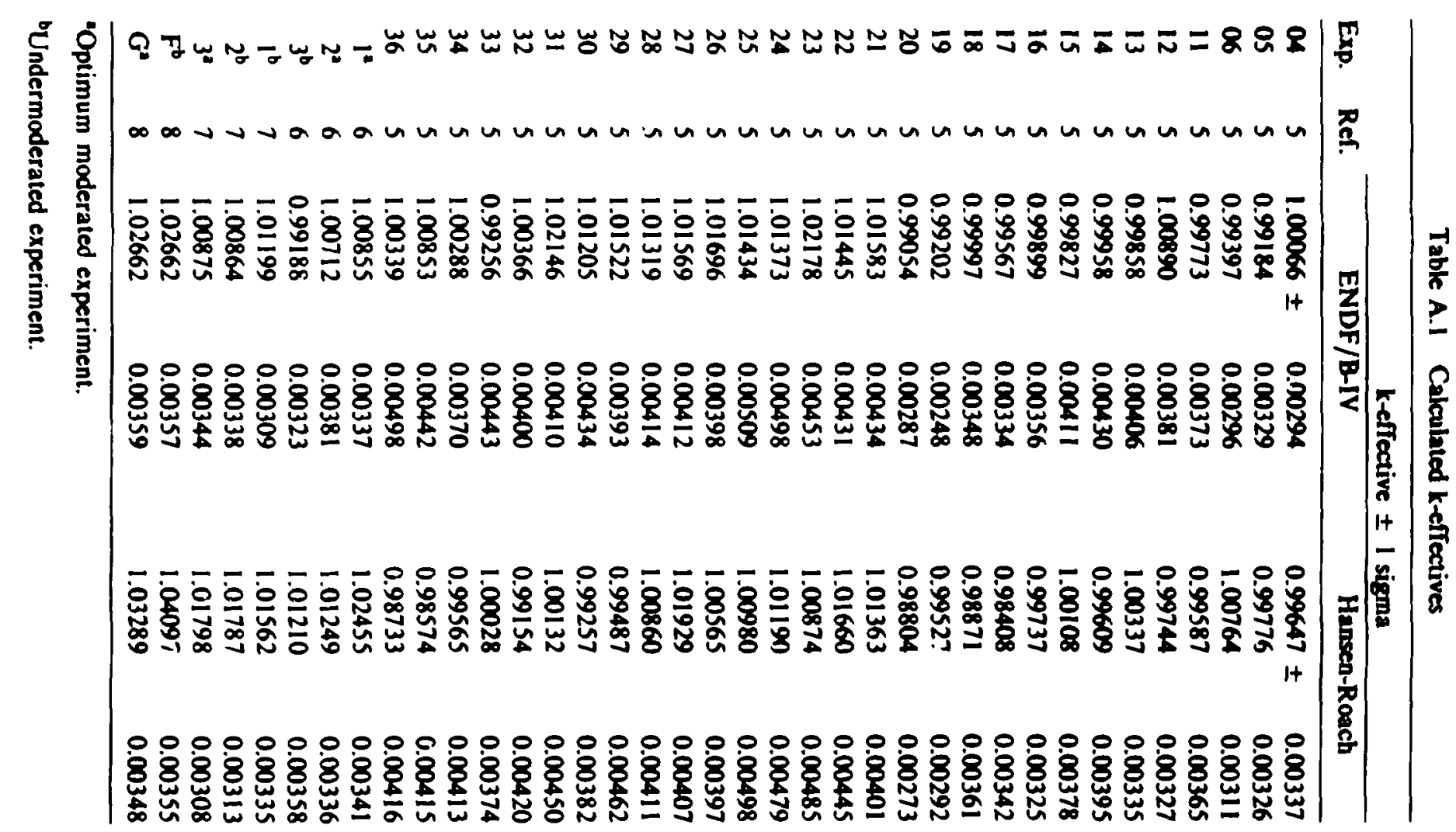




\section{APPENDIX B \\ COMPARISON OF NUMBER DENSITY CALCULATIONS}

In an effort to standardize the calculation of number densities, and reduce the amount of user required input needed for a sucessful calculation, SCALE internally calculates number densities. From the Standard Composition Library' the user can designate the material to be a mixture of one or more standard compositions. These compositions iriclude elements, compoun's, alloys, solutions, and arbitrary materials (used to build componnds and alloys not available in the Standard Composition Library). For standard compositions taken from the Standard Composition Library, the user will have to enter the volume fraction or theoretical density of the standard composition in the mixture, and other engineering type data (see Ref. 1).

For selected experiments, the number densities were calculated by hand and compared with number densities used in Ref. 5 and the number densities generated by SCALE. Table A.l contains these values and from the comparison it is determined ihat SCALE accurately calculates material number densities in a standardized form.

Table B.1 Comparison of number densities*

\begin{tabular}{|c|c|c|c|c|}
\hline $\begin{array}{c}\text { Case } \\
\text { no. }\end{array}$ & Element & $\begin{array}{c}\text { Hand } \\
\text { calculation }\end{array}$ & $\begin{array}{l}\text { Value from } \\
\text { ref. } 5\end{array}$ & $\begin{array}{l}\text { SCALE } \\
\text { calculation }\end{array}$ \\
\hline \multirow[t]{5}{*}{$4-6$} & ${ }^{233} \mathrm{U}$ & $6.9821 \mathrm{E}-5$ & $8.9443 \mathrm{E}-5$ & $8.9447 \mathrm{E}$ \\
\hline & ${ }^{238} \mathrm{U}$ & $6.2356 \mathrm{E}-3$ & $6.2094 \mathrm{E}-3$ & $6.2097 \mathrm{E}-3$ \\
\hline & $\mathbf{F}$ & $2.5304 \mathrm{E}-2$ & $2.5195 \mathrm{E}-2$ & $2.5197 \mathrm{E}-2$ \\
\hline & $\mathbf{H}$ & $3.7886 \mathrm{E}-2$ & $3.7727 \mathrm{E}-2$ & $3.7755 \mathrm{E}-2$ \\
\hline & $C$ & $1.8215 \mathrm{E}-2$ & $1.8138 \mathrm{E}-2$ & $1.8152 \mathrm{E}-2$ \\
\hline \multirow[t]{5}{*}{33,34} & ${ }^{233} \mathrm{U}$ & $1.1599 \mathrm{E}-4$ & $1.1601 \mathrm{E}-4$ & $1.1644 \mathrm{E}$ \\
\hline & ${ }^{238} \mathrm{U}$ & $2.1852 \mathrm{E}-3$ & $2.1856 \mathrm{E}-3$ & $2.1936 \mathrm{E}-3$ \\
\hline & $\mathbf{F}$ & $4.6024 \mathrm{E}-3$ & $4.6031 \mathrm{E}-3$ & $4.6201 \mathrm{E}-3$ \\
\hline & H & $5.6605 \mathrm{E}-2$ & $5.6612 \mathrm{E}-\mathrm{L}$ & $5.6891 \mathrm{E}-2$ \\
\hline & 0 & $3.2904 \mathrm{E}-2$ & $3.2909 \mathrm{E}-2$ & $3.306 ? \mathrm{E}-2$ \\
\hline \multirow[t]{5}{*}{35} & ${ }^{235} \mathrm{U}$ & $1.1613 \mathrm{E}-4$ & $1.1614 \mathrm{E}-4$ & $1.1642 \mathrm{E}-4$ \\
\hline & ${ }^{238} \mathrm{U}$ & $2.1878 \mathrm{E}-3$ & $2.1881 \mathrm{E}-3$ & $2.1932 \mathrm{E}$ \\
\hline & $\mathbf{F}$ & $4.6080 \mathrm{E}-3$ & $4.6085 \mathrm{E}-3$ & $4.6192 \mathrm{E}-3$ \\
\hline & H & $5.6947 \mathrm{E}-2$ & $5.6909 \mathrm{E}-2$ & $5.6893 \mathrm{E}-2$ \\
\hline & 0 & $3.3081 \mathrm{E}-2$ & $3.3063 \mathrm{E}-2$ & 3.3666E-2 \\
\hline \multirow[t]{5}{*}{36} & ${ }^{235} \mathrm{U}$ & $1.1501 \mathrm{E}-4$ & $1.1499 \mathrm{E}-4$ & $1.1644 \mathrm{E}-4$ \\
\hline & ${ }^{231} \mathrm{U}$ & $2.1666 \mathrm{E}-3$ & $2.1664 \mathrm{E}-3$ & $2.1936 \mathrm{E}-3$ \\
\hline & $\mathbf{F}$ & $4.5632 \mathrm{E}-3$ & $4.5628 \mathrm{E}-3$ & $4.6201 \mathrm{E}-3$ \\
\hline & H & $3.3086 \mathrm{E}-2$ & $3.3082 \mathrm{E}-2$ & $3.3066 \mathrm{E}-2$ \\
\hline & 0 & $5.7045 E-2$ & $5.7038 \mathrm{E}-2$ & $5.6891 \mathrm{E}-2$ \\
\hline
\end{tabular}

*atoms/barn-cm 
APPENDIX C

CODE INPUT FOR ALL CASES

Case 4

$=$ CSAS25

BRITISH HANDBOOK OF CRITICALITY SAFETY U(1.42)F4 \& PARAFFIN (CASE 04) HANSEN-ROACH INFHOMMEDIUM

UF4 $\quad 10.4903293922351 .40239223898 .5977$ END

PARAFFIN 10.4572 END

END COMP

BRITISH HANDBOOK OF CRITICALITY SAFETY U(1.42)F4 \& PARAFFIN (CASE 04) READ PARM END PARM

READ GEOM

CUBOID 1 I 2P46.55 2P46.50 2P61.9

END GEOM

END DATA

END

Case 5

$=$ CSAS25

BRITISH HANDBOOK OF CRITICALITY SAFETY U(1.42)F4 \& PARAFFIN (CASE 05) HANSEN-ROACH INFHOMMEDIUM

UF4 $\quad 10.49032: 3922351.40239223898 .5977$ END

PARAFFIN 10.4572 END

END COMP

BRITISH HANDBOOK OF CRITICALITY SAFETY U(1.42)F4 \& PARAFFIN (CASE 05) READ PARM END PARM

READ GEOM

CUBOID 1 I 2P50.00 2P49.95 2P51.55

END GEOM

END DATA

END

Case 6

= CSAS25

BRITISH HANDBOOK OF CRITICALITY SAFETY U(1.42)F4 \& PARAFFIN (CASE 06) HANSEN-ROACH INFHOMMEDIUM

UF4 10.4903293922351 .40239223898 .5977 END

PARAFFIN 10.4572 END

END COMP

BRITISH HANDBOOK OF CRITICALITY SAFETY U(1.42)F4 \& PARAFFIN (CASE 06)

READ PARM END PARM

READ GEOM

CUBOID 112 2P65.35 2P65.3 2P 37.1

END GEOM

END DATA

END 
Case 11

\section{$=$ CSAS25}

RAFFETY AND MILHALCZO U(2)F4-1 REFLECTED (CASE 11) HANSEN-ROACH INFHOMMEDIUM

U-235 10 1.5811E-4 END

U-238 $107.6467 E-3$ END

H 103.0864 E-2 END

C $101.4839 \mathrm{E}-2$ END

F $103.1219 E-2$ END

PARAFFIN 21.0 END

PLEXIGLASS 30.918 END

AL 30.062 END

END COMP

RAFFETY AND MALHALCZO U(2)F4-1 REFLECTED (CASE II)

READ PARM RUN $=$ YES PLT $=$ YES END PARM

READ GEOM

UNIT I

CUBOID : / 4P28.110 2P56.64

REPLICATE $225 * 3.0480 .05$

UNIT 2

CUBOID 3 I 4P28.110 2*0.0

REPLICATE $324 * 3.0480 .03 .0485$

END GEOM

READ ARRAY

NUX $=1 \quad$ NUY $=1 \quad N U Z=2$

FILL 2 I END FILL

END ARRAY

READ BIAS ID $=40026$ END BIAS

READ PLOT TTL ='XZ SLICE OF CASE $\|$ SHOWING BIASING REGIONS'

$X U L=-1 \quad Y U L=20 \quad Z U L=146$

$X L R=88 \quad Y L R=20 \quad Z L R=-3$

$U A X=1 \quad W D N=-1 \quad N A X=130 \quad \mathrm{NCH}={ }^{\prime} 0123456^{\prime}$

PIC $=$ WTS

END PLOT

END DATA

END

Case 12

\section{$=$ CS.AS25}

RAFFETY AND MILHALCZO U(2)F4-1 UNREFLECTED (CASE 12)

HANSEN-ROACH INFHOMMIDIUM

U-235 101.5811 E-4 END

U-238 $107.6467 E-3$ END

H 103.0864 E-2 END

C $101.4839 \mathrm{E}-2$ END

F $103.1219 \mathrm{E}-2$ END

FND COMP

RAFFETY AND MALHALCZO U(2)F4-1 UNREFLECTED (CASE 12)

READ PARM END PARM

READ GEOM

CUBOID I I 35.735 -35.735 $35.735-35.73547 .07-47.07$

END GEOM

END DATA

END 
Case 13

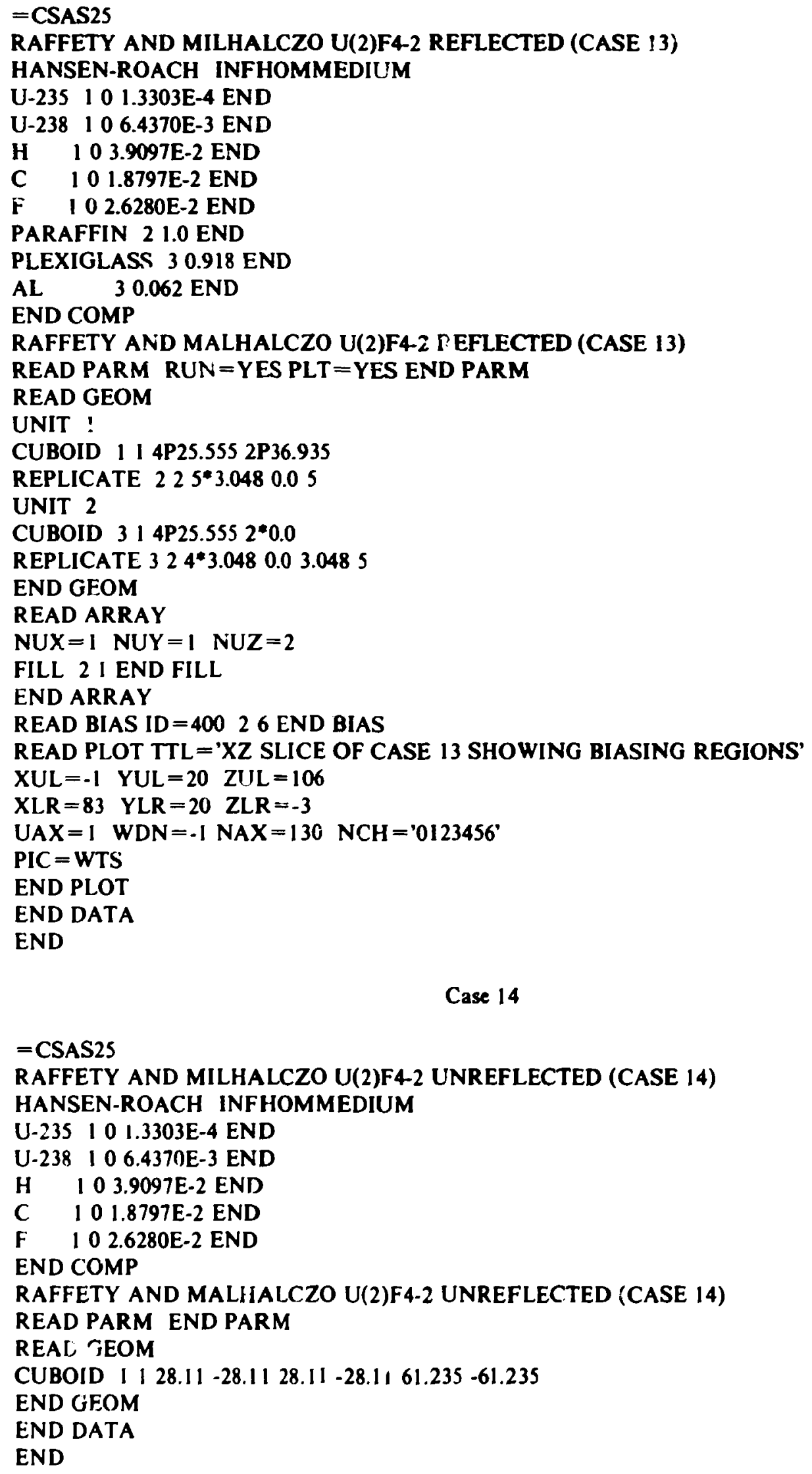


Case 15

$=$ CSAS25

RAFFETY AND MILHALCZO U(2)F4-3 REFLECTED (CASE 15) HANSEN-ROACH INFHOMMEDIUM

U-23j 10 1.1191E-.' END

U-238 $105.413 \angle L-3$ END

H 10 4.5472E-2 END

C $102.1861 \mathrm{E}-2$ END

F 10 2.2109E-2 END

PARAFFIN 21.0 END

PLEXIGLASS 30.918 END

AL 30.062 END

END COMP

RAFFETY AND MALHALCZO U(2)F4-3 REFLECTED (CASE 15)

READ PARM RUN $=$ YES PLT $=$ YES END PARM

READ GEOM

UNIT 1

CUBOID 114 4P26.835 2P27.145

REPLICATE $225 * 3.0480 .05$

UNIT 2

CUBOID 314 P $26.8352 * 0.0$

REPLICATE $324^{*} 3.0480 .03 .0485$

END GEOM

READ ARRAY

NUX $=1 \quad$ NUY $=1 \quad \wedge U Z=2$

FILL 2 I END FILL

END ARRAY

READ BIAS ID $=40026$ END BIA.S

READ PLOT TTL $=$ 'XZ SLICE OF CASE 15 SHOWING BIASING REGIONS'

$X U L=-1 \quad Y U L=20 \quad Z U L=86$

$X L R=86 \quad Y L R=20 \quad Z L R=-3$

$\mathrm{UAX}=1 \quad$ WDN $=.1 \quad \mathrm{NAX}=130 \quad \mathrm{NCH}={ }^{\prime} 0123456^{\prime}$

PIC $=$ WTS

END PLOT

END DATA

END

Case 16

\section{$=$ CSAS25}

RAFFETY AND MILHALCZO U(2)F4-4 REFLECTED (CASE 16)

HANSEN-ROACH INFHOMMEDIUM

U-235 $100.9924 E-4$ END

U-238 10 4.7998E-3 END

$\mathrm{H} \quad 104.9212 \mathrm{E}-2$ END

C I 02.3660 E-2 END

F $101.9596 \mathrm{E}-2$ END

PARAFFIN 21.0 END

PLEXIGLASS 30.918 ENDD

AL 30.062 END

END COMP 


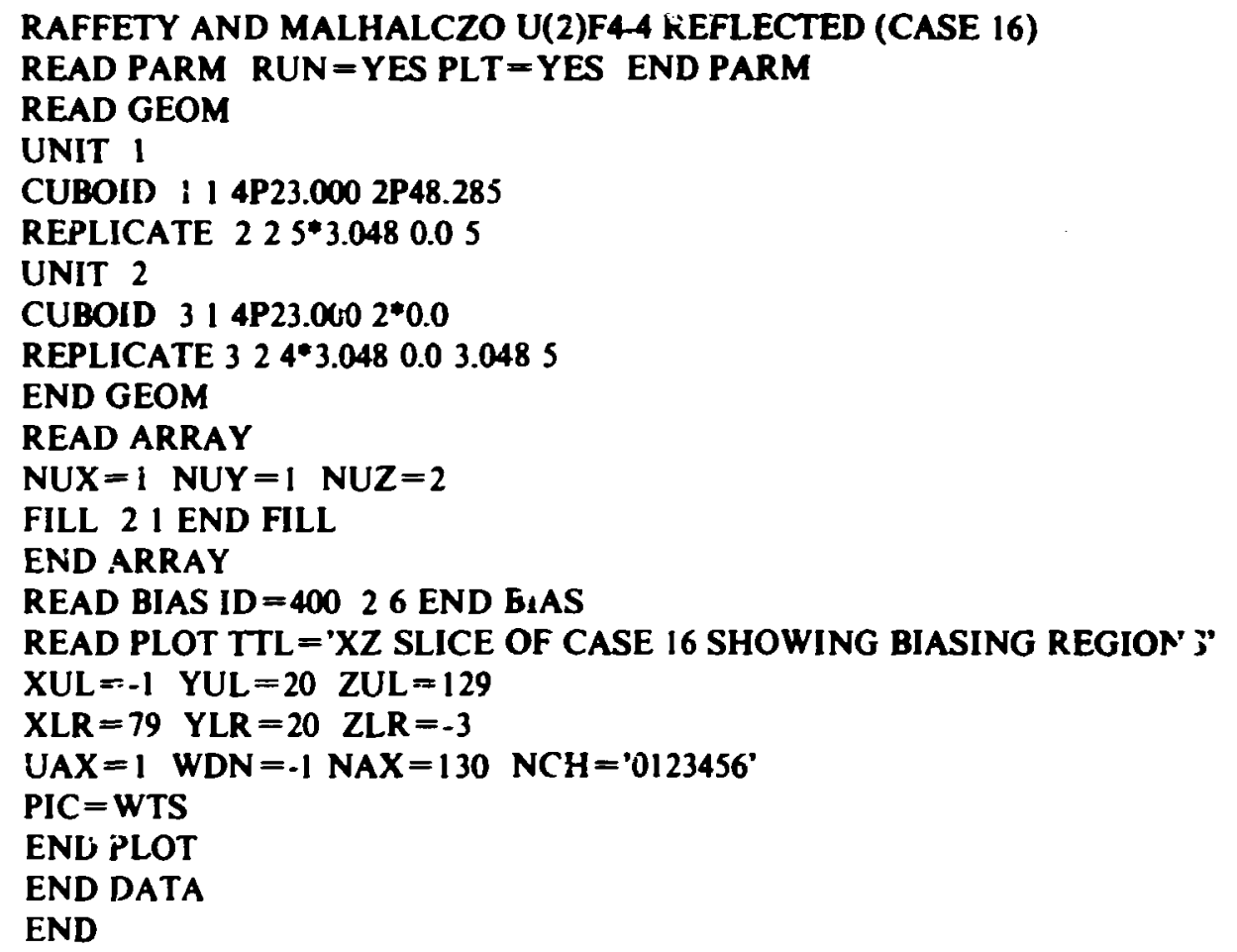

Case 17

$=$ CSAS25

RAFFETY AND MI!HALCZO U(2)F4-5 REFLECTED (CASE 17)

HANSEN-ROACH INFHOMMEDIUM

U-235 100.8667 E-4 END

U-238 I 0 4.1941E-3 END

H 10 5.3187E-2 END

C $102.5570 \mathrm{E}-2$ END

F $101.7123 E-2$ END

POLYETHYLENE 21.0 END

PLEXIGLASS 30.918 END

AL 30.062 END

END COMP

RAFFETY AND MALHALCZO U(2)F4-5 REFLECTED (CASE 17)

READ PARM RUN = YES PLT = YES END PARM

READ GEOM

UNIT 1

CUBOID 11 2P28.160 2P30.645 2P27.040

REPLICATE $225 * 3.0480 .05$

UNIT 2

CUBOID $312 \mathrm{2P} 28.1602 \mathrm{P} 30.6452 * 0.0$

REPLICATE $324 * 3.0480 .03 .0485$

END GEOM

READ ARRAY

NUX $=1 \quad$ NUY $=1 \quad$ NUZ $=2$

FILL 2 I END FILL

END ARRAY 
READ BIAS ID $=40026$ END BIAS

READ PLOT TTL='XZ SLICE OF CASE 17 SHOWING BIASING REGIONS'

$X U L=-1 \quad Y U L=20 \quad Z U L=86$

$X L R=89$ YLR $=20 \quad Z L R=-3$

$\mathrm{UAX}=1$ WDN $=-1$ NAX $=130 \mathrm{NCH}={ }^{\circ} 0123456^{\circ}$

PIC $=$ WTS

END PLOT

END DATA

END

Case 18

$=$ CSAS25

RAFFETY AND MILHALCZO U(2)F4-5 UNREFLECTED (CASE 18)

HANSEN-ROACH INFHOMMEDIUM

U-235 $100.8667 E-4$ END

U-238 $104.1941 E-3$ END

H 105.3187 E-2 END

C 102.5570 E-2 END

F 10 1.7123E-2 END

END COMP

RAFFETY AND MALHALCZO U(2)F4-5 UNREFLECTED (CASE18)

READ PARM END PARM

READ GEOM

CUBOID I $130.65-30.6533 .27-33.2733 .26$-33.26

END GEOM

END DATA

END

Case 19






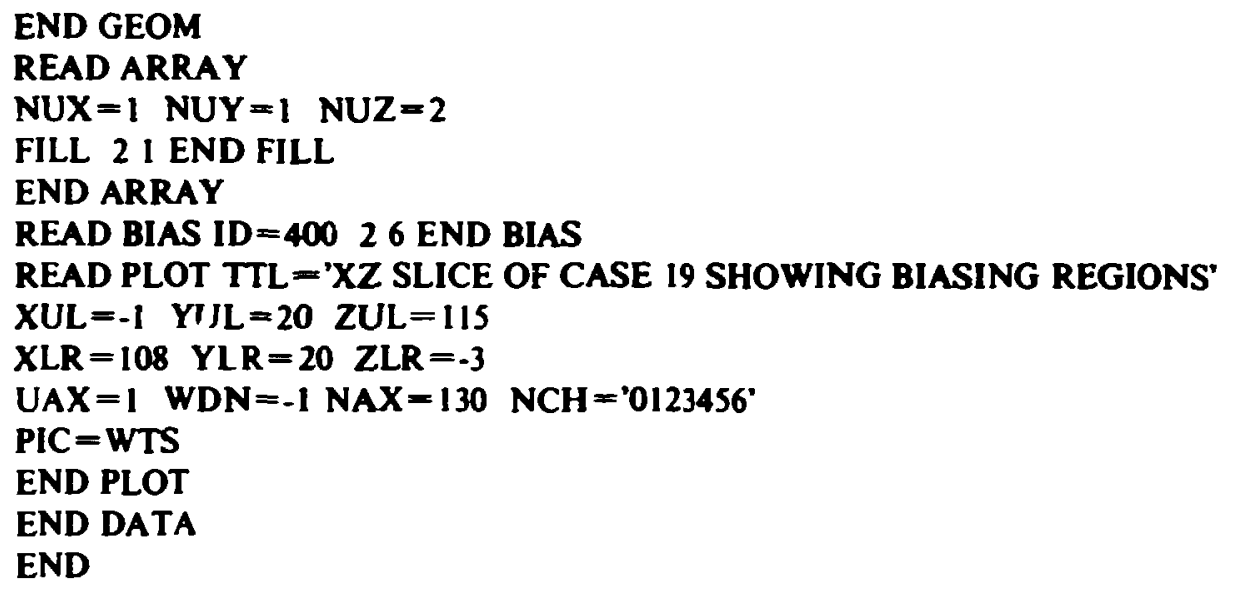

Case 20

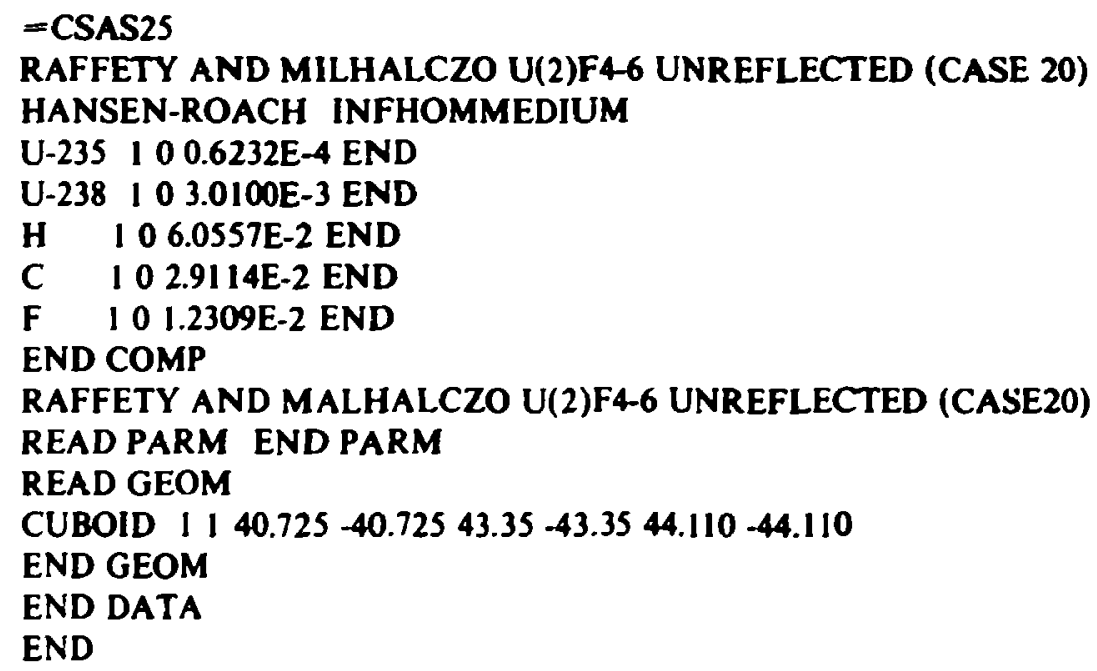




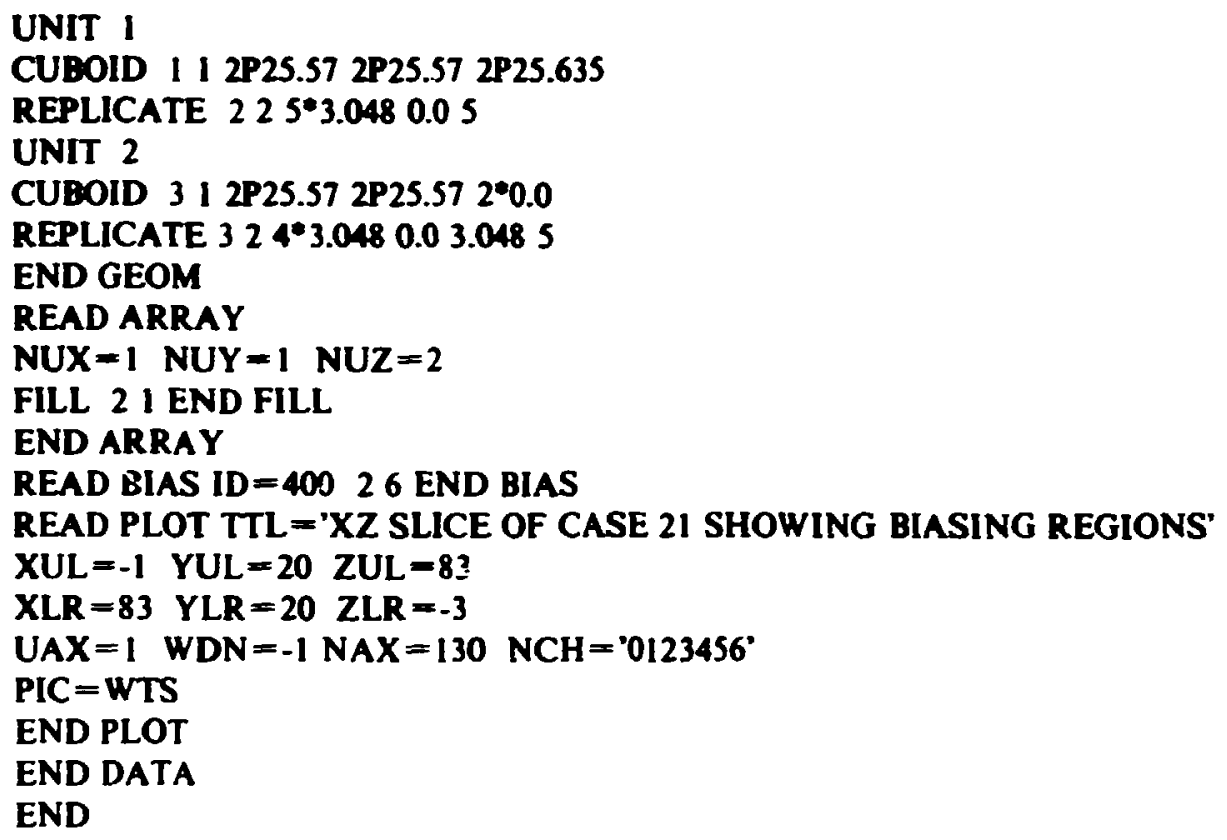




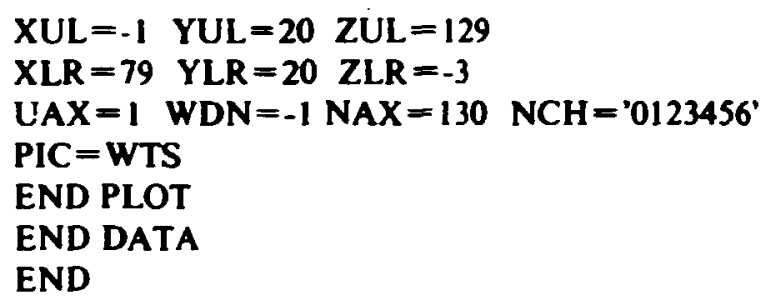

Case 23

$=$ CSAS25

RAFFETY AND MILHALCZO U(3)F4-1 REFLECTED (CASE 23)

HANSEN-ROACH INFHOMMEDIUM

U-235 10 2.3494E-4 END

U-238 $107.4999 E-3$ END

H $103.1341 E-2$ END

C 10 1.5057E-2 END

F 10 3.0939E-2 END

PARAFFIN 21.0 END

PLEXIGLASS 30.918 END

AL $\quad 30.062$ END

END COMP

RAFFETY AND MALHALCZO U(3)F4-1 REFLECTED (CASE 23)

READ PARM RUN $=$ YES PLT $=$ YES END PARM

READ GEOM

UNIT 1

CUBOID $112 \mathrm{P} 23.0102 \mathrm{P} 23.0102 \mathrm{P} 33.785$

REPLICATE $225 \% 3.0480 .05$

UNIT 2

CUBOID $312 \mathrm{P} 23.0102 \mathrm{P} 23.0102 * 0.0$

REPLICATE $324 * 3.0480 .03 .0485$

END GEOM

READ ARRAY

NUX $=1 \quad$ NUY $=1 \quad$ NUZ $=2$

FILL 2 I END FILL

END ARRAY

READ BIAS ID $=40026$ END BIAS

READ PLOT TTL $=$ 'XZ SLICE OF CASE 23 SHOWING BIASING REGIONS'

$X U L=-1 \quad Y U L=20 \quad Z U L=99$

$X L R=79 \quad$ YLR $=20 \quad$ ZLR $=-3$

$\mathrm{UAX}=1$ WDN $=-1 \mathrm{NAX}=130 \mathrm{NCH}={ }^{\prime} 0123456^{\prime}$

$P I C=$ WTS

END PLOT

END DATA

END 
Case 24

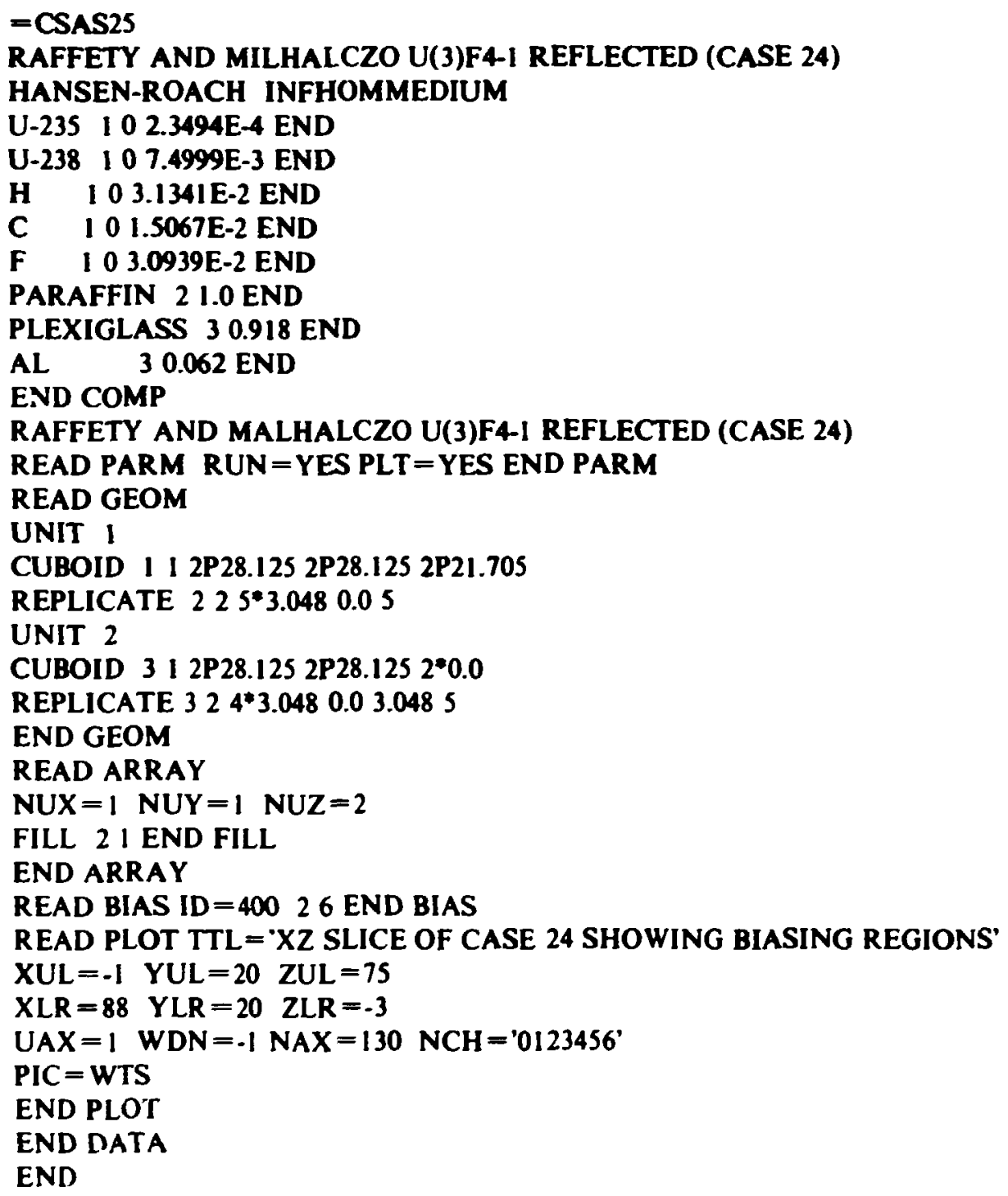


RAFFETY AND MALHALCZO U(3)F4-I REFLECTED (CASE 25)

READ PARM RUN =YES PLT = YES END PARM

READ GEOM

UNIT 1

CUBOID I I 2P 30.680 2P 30.680 2P19.335

REPLICATE $225 * 3.0480 .05$

UNIT 2

CUBOID $312 P 30.6802 P 39.6802 * 0.0$

REPLICATE $324 * 3.0480 .03 .0485$

END GEOM

READ ARRAY

NUX $=1$ NUY $=1 \quad$ NUZ $=2$

FILL 21 END FILL

END ARRAY

READ BIAS ID $=40026$ END BIAS

READ PLOT TTL = 'XZ SLICE OF CASE 25 SHOWING BIASING REGIONS'

$\mathrm{XUL}=-1 \quad \mathrm{YUL}=20 \quad \mathrm{ZUL}=71$

$X L R=93$ YLR $=20 \quad$ ZLR $=-3$

UAX $=1$ WDN $=-1$ NAX $=130 \quad \mathrm{NCH}={ }^{\prime} 0123456^{\circ}$

PIC $=$ WTS

END PLOT

END DATA

END

Case 26

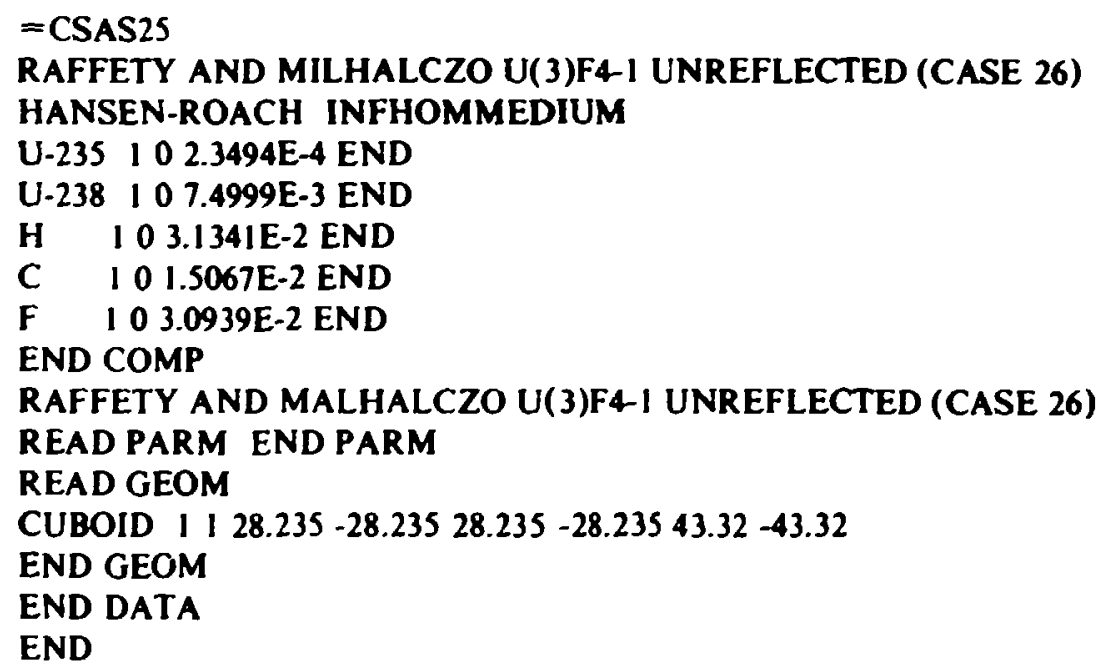


Case 27

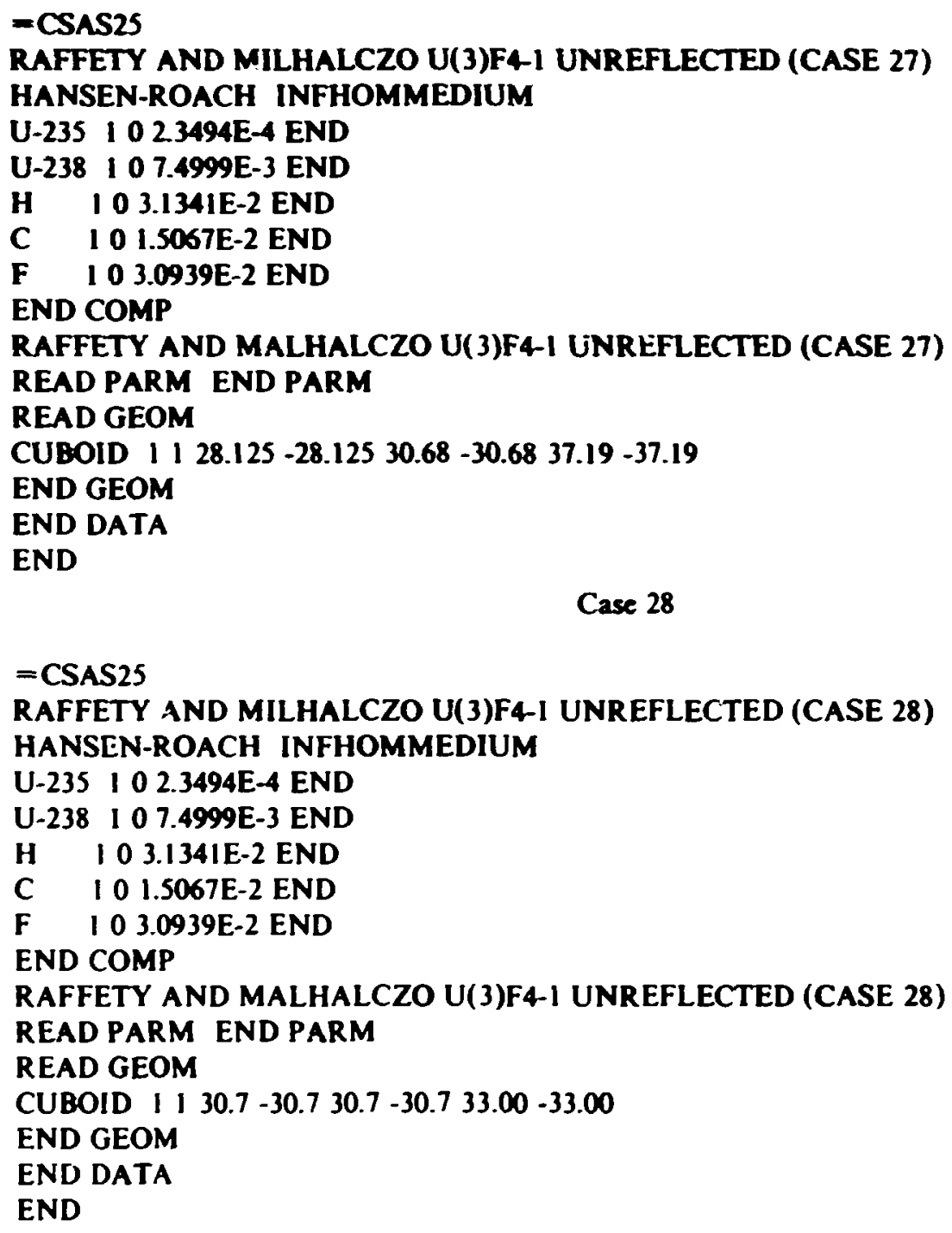




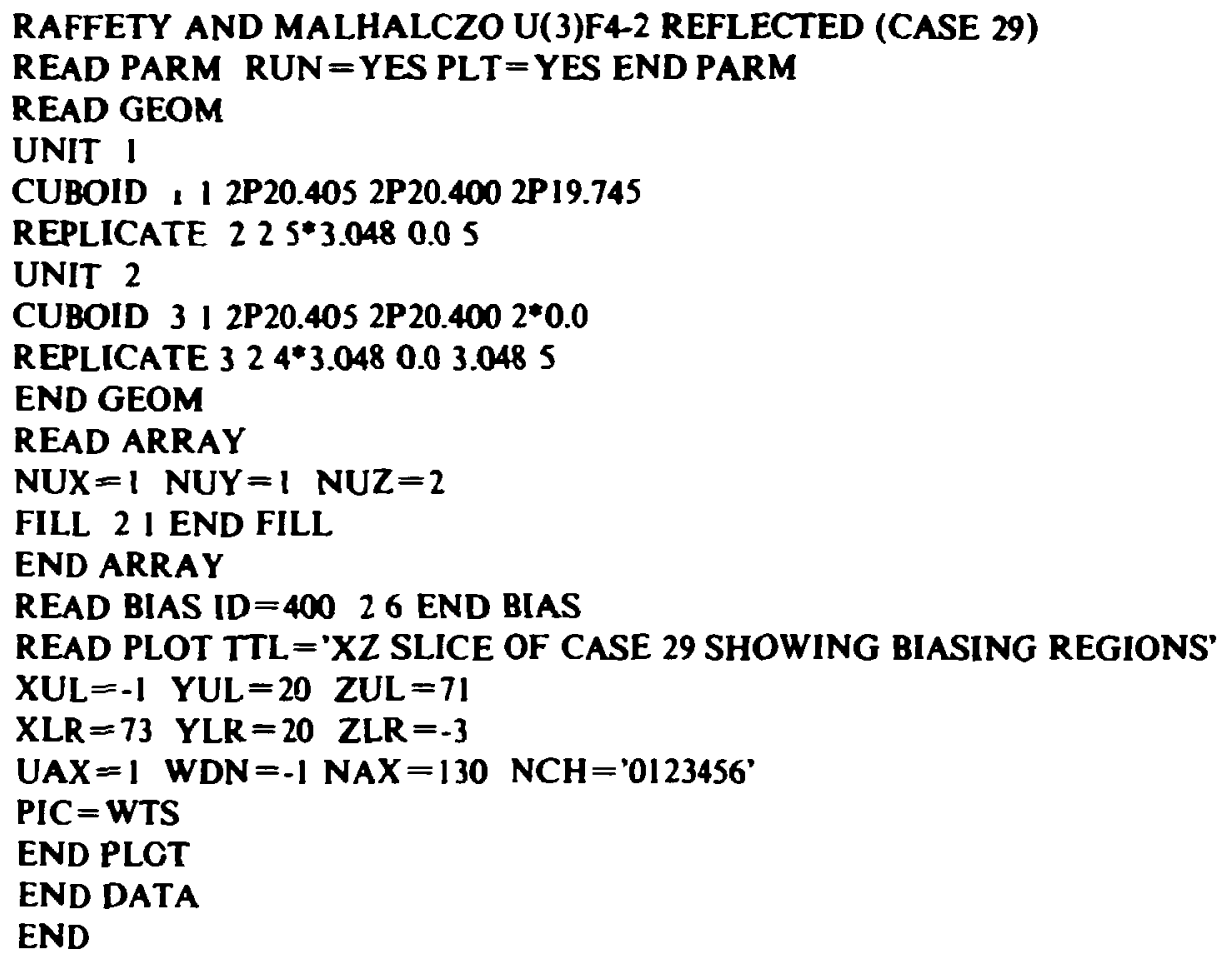

Case 30

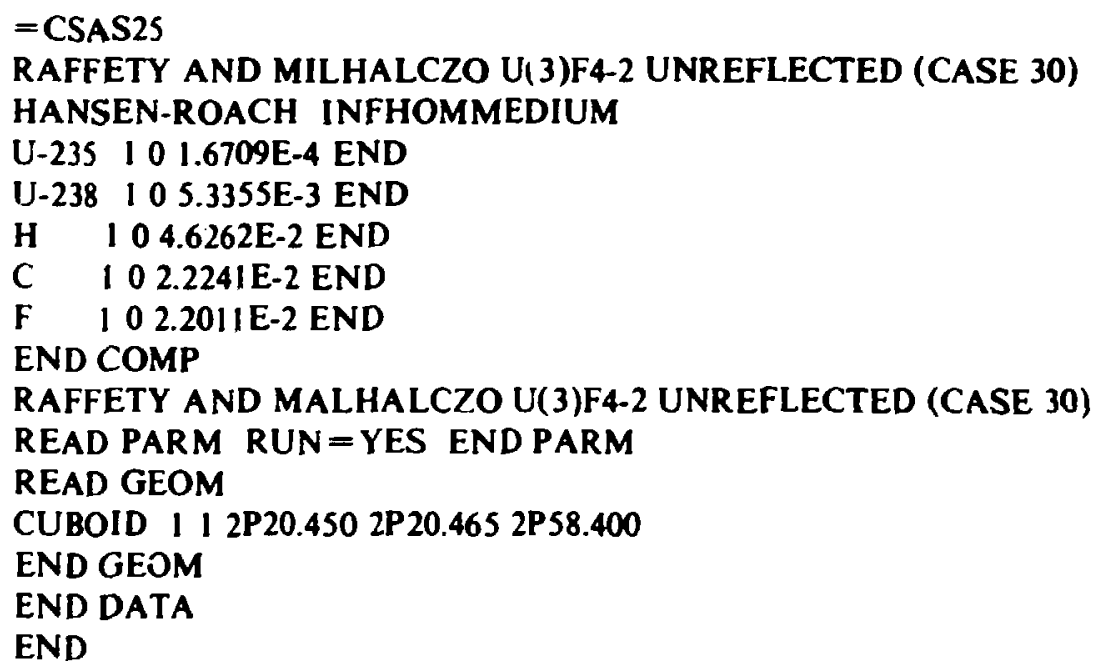


Case 31

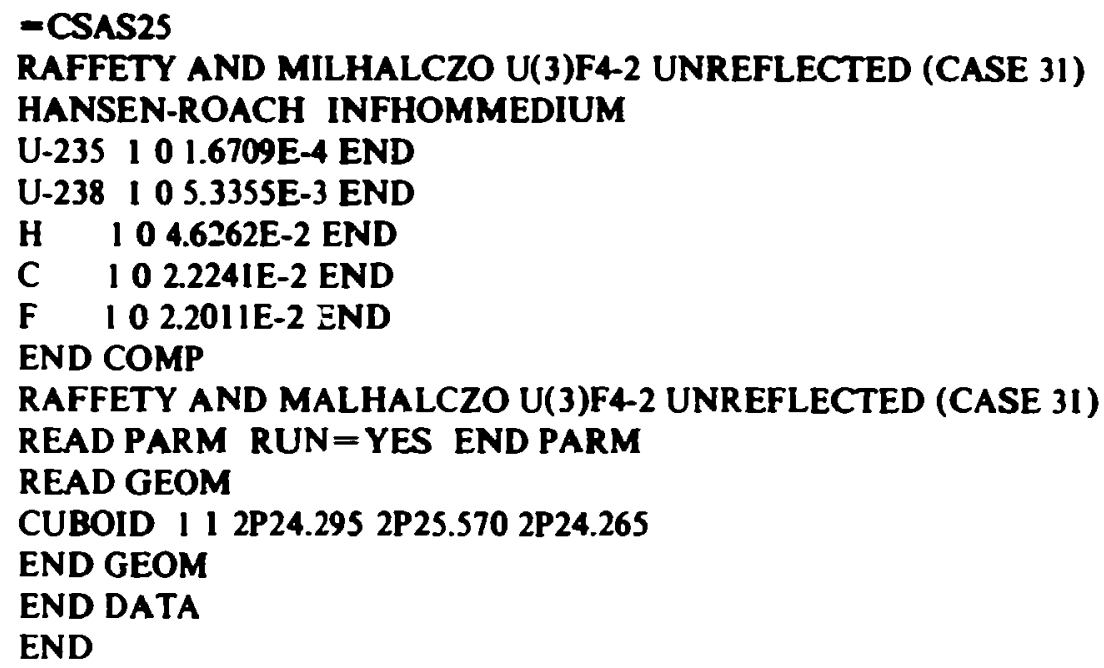

Case 33

$=$ CSAS25

CRITICAL REFLECTED CYLINDER OF AQUEOUS U(4.98)O2F2 (CASE 33) HANSEN-ROACH INFHOMMEDIUM

SOLNUO2F2 1910.360 .01298922354 .989223895 .02 END

SS304 2 1.0 END

H2O 31.0 END

CD 4 1.0 END

END COMP

CRITICAL REFLECTED CYLINDER OF AQUEOUS U(4.98)O2F2 (CASE 33)

READ PARM RUN = YES END PARM

READ GEOM 


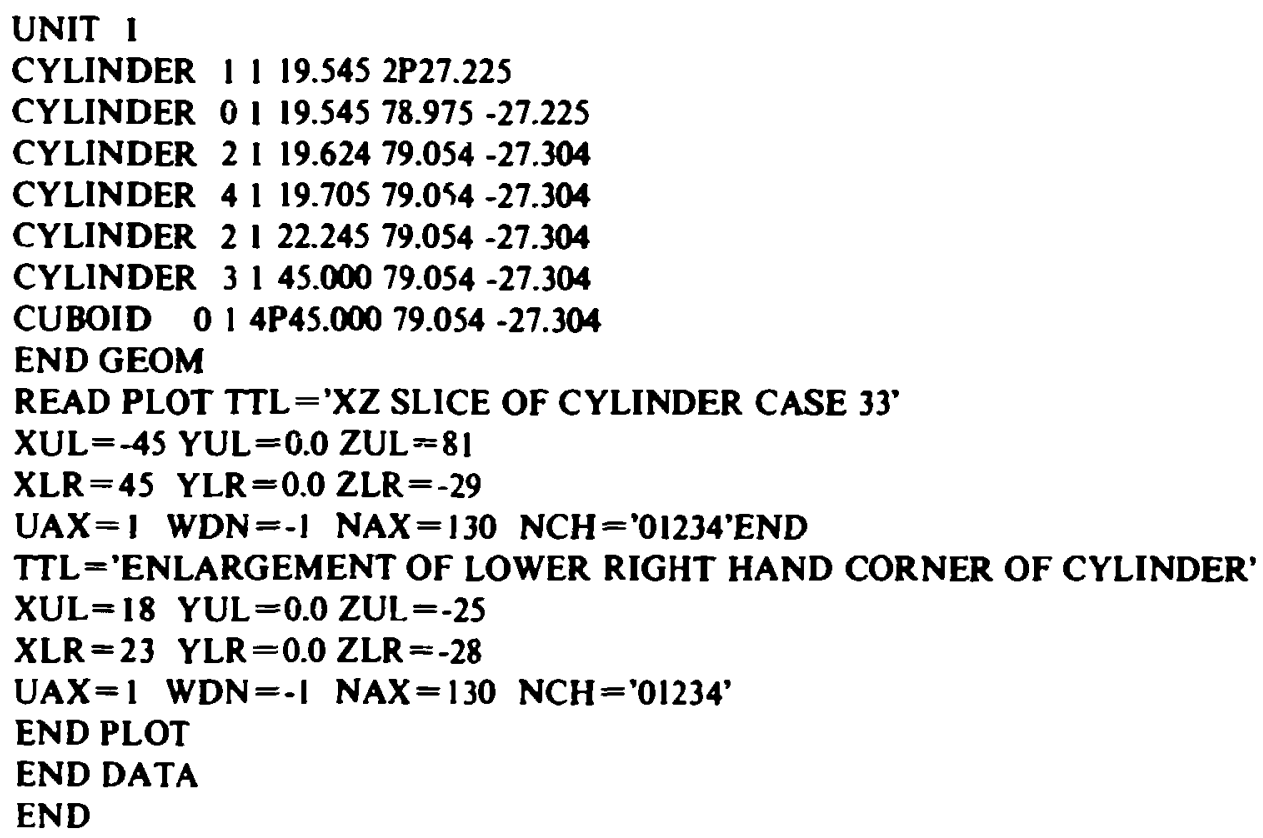

Case 34

$=$ CSAS25

CRITICAL REFLECTED CYLINDER OF AQUEOUS U(4.98)O2F2 (CASE 34)

HANSEN-ROACH INFHOMMEDIUM

SOLNUO2F2 1910.360 .01298922354 .989223895 .02 END

SS304 2 1.0 END

H2O 31.0 END

END COMP

CRITICAL REFLECTED CYLINDER OF AQUEOUS U(4.98)O2F2 (CASE 34)

READ PARM RUN = YES END PARM

READ GEOM

UNIT 1

CYLINDER $1116.5102 \mathrm{P} 71.500$

CYLINDER $0116.510 \quad 172.400-71.500$

CYLINDER $2116.589172 .479-71.579$

CYLINDER $2119.129172 .479-71.579$

CYLINDER $3145.003172 .479-71.579$

CUBOID 0 I 4 4P45.0.0 $172.479-71.579$

END GEOM

READ PLOT TTL = 'XZ SLICE OF CYLINDER CASE 34'

$X U L=.45 \quad Y U L=0.0 \mathrm{ZUL}=174$

$X L R=45 \quad Y L R=0.0 Z L R=-73$

$U A X=1$ WDN $=-1 \quad \mathrm{NAX}=130 \quad \mathrm{NCH}={ }^{\prime} 0123^{\prime} \mathrm{END}$

TTL $=$ 'ENLARGEMENT OF LOWER RIGHT CORNER OF CYLINDER'

$X U L=15 \quad Y U L=0.0 \mathrm{ZUL}=-69$

$X L R=20 \quad Y L R=0.0 \quad Z L R=-73$

$U A X=1$ WDN $=.1 \quad \mathrm{NAX}=130 \mathrm{NCH}={ }^{\prime} 0123^{\prime}$

END PLOT

END DATA

END 
Case 35

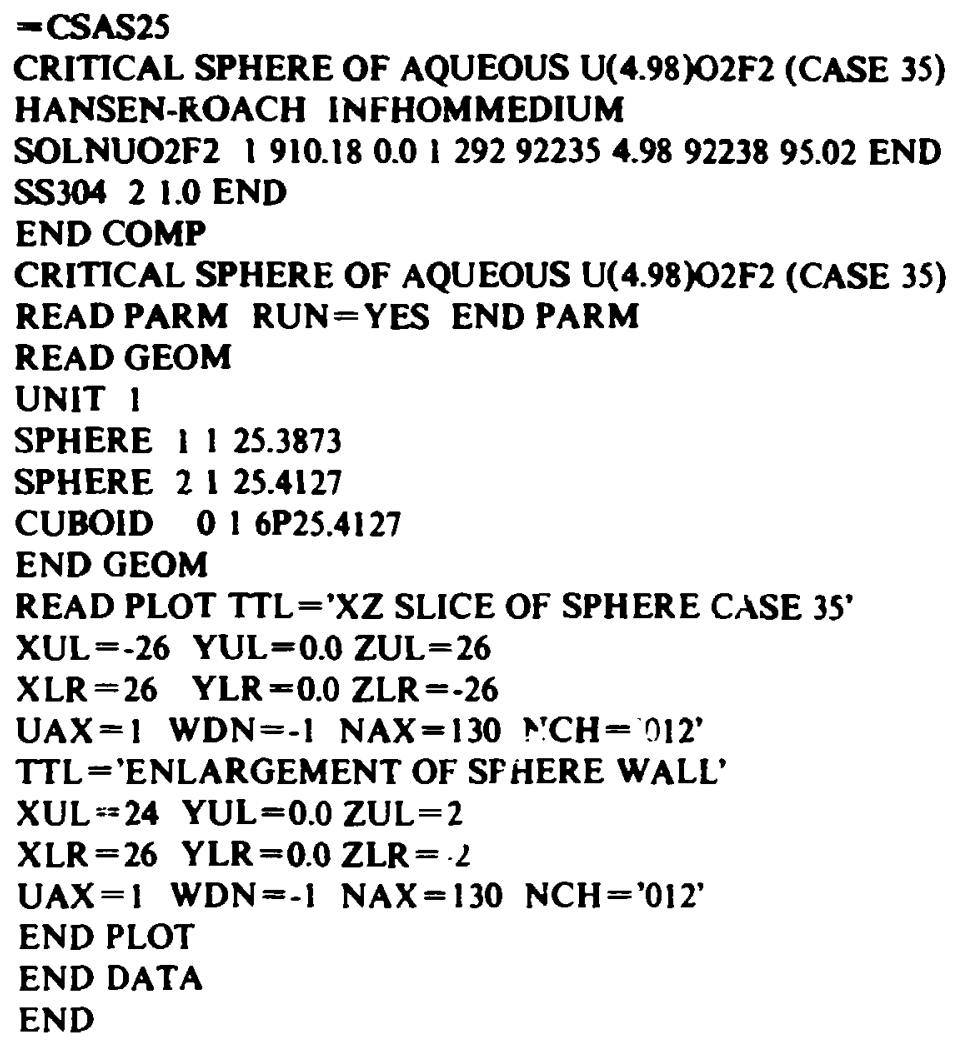


Case 41

//JOBCARD

// EXEC SPDASCR

T.GEEOOOOO.RSTI.HSNRCH.RFPI

//* PREVIOUS TWO LINES CLEAR T.GEEOOOOO.RSTI.HSNKCH.RFPI SO

//* A RESTART FILE CAN BE WRITTEN ON UNIT 30 IN THIS FILE

//MIKE EXEC Y12CSG,REGION.GO $=1024 \mathrm{~K}$

//FT84FO01 DD DSN = T.GEE00000.HSNRCHI,DISH $=$ SHR

//FT30F001 DD DSN=T.GEEOOOOD.RSTI.HSNRCH.RFP1,UNIT =SPDA,

// SPACE $=($ TRK, $(20,10)), D C B=(\operatorname{RECFM}=V B S, L R E C L=X, B L K S I Z E=3156, B U F L=4038)$,

$/ / \mathrm{DISP}=(, \mathrm{CATLG})$

//GO.SYSIN DD *

$=$ CSAS25

F.OCKY FLATS CRITICALS NUREG/CR-1071 EXPERIMENT NUMBER 1 (HANSEN-ROACH) 2:8GROUPNDF4 LATTICECELL

HAVEREDEFINED

U3O8 1 5.4078E-1 293.0922340.0392235 4.46922360.089223895.43 END

H2O 1 8.9514E-2 END

ARBM-BAGGIE $1.03000100114 .0 \mathrm{i} 601284.980161 .2011 .9134 \mathrm{E}-2$

END

ARBM-ALI100 $1.030011302799 .18260000 .5290000 .229 .5390 E-1$

END

ARBM-TAPE(VINYL) 1.0700010015 .92601245 .91801610 .8217000

$25.73200406 .9220001 .6820001 .121 .1115 \mathrm{E}-2$ END

ARBM-TAPE(MYLAR) 1.0300010016 .83601265 .50801627 .022

1.7491E-2 END

ARBM-MODERATOR 1.185300010017 .83601259 .49801632 .483 END

ARBM-PLEX(REG) 1.0300010017 .84601259 .59801632 .234

1.1773 END

ARBM-PLEX(PAPER) 1.0300010016 .48601242 .17801649 .54

3.7534E-3 END

ARBM-PLEX(GLUE) 1.03000100111 .67601286 .2980161 .204

1.1648E-3 END

ARBM-PLEX(TRIS) 1.0800110017 .16601252 .0370140 .16801629 .82

$15 \cap 311.02170001 .81350794 .260350812 .84051 .2757$ END

ARE V-PLEX(PAPER) 1.0300010016 .48601242 .17801649 .55

3.7534E-3 END

ARBM-PLEX(GLJE) 1.03000100111 .67601286 .2980161 .205

1.1648E-3 END

ARBM-FILLER 1.185300010017 .83601259 .49801632 .486 .88 END

END COMP

SPHTRIANGP 19.946218 .5857 I 318.95792 END

ROCKY FLATS CRITICALS NUREG/CR-1071 EXPERIMENT NUMBER I (HANSEN-ROACH)

READ PARM RUN $=$ YES NPG $=500$ RES $=103$ WRS $=30$

END PARM

READ GEOM

UNIT I

COM = 'FUEL BOX 15.28 CM ON A SIDE WITH .15 CM WALLS .05CM STACKING VOID'

CUBOID $1 / 6 \mathrm{P} 7.49$

CUBOID $216 \mathrm{P} 7.64$

CUBOID $0 \perp 6 P 7.6650$ 


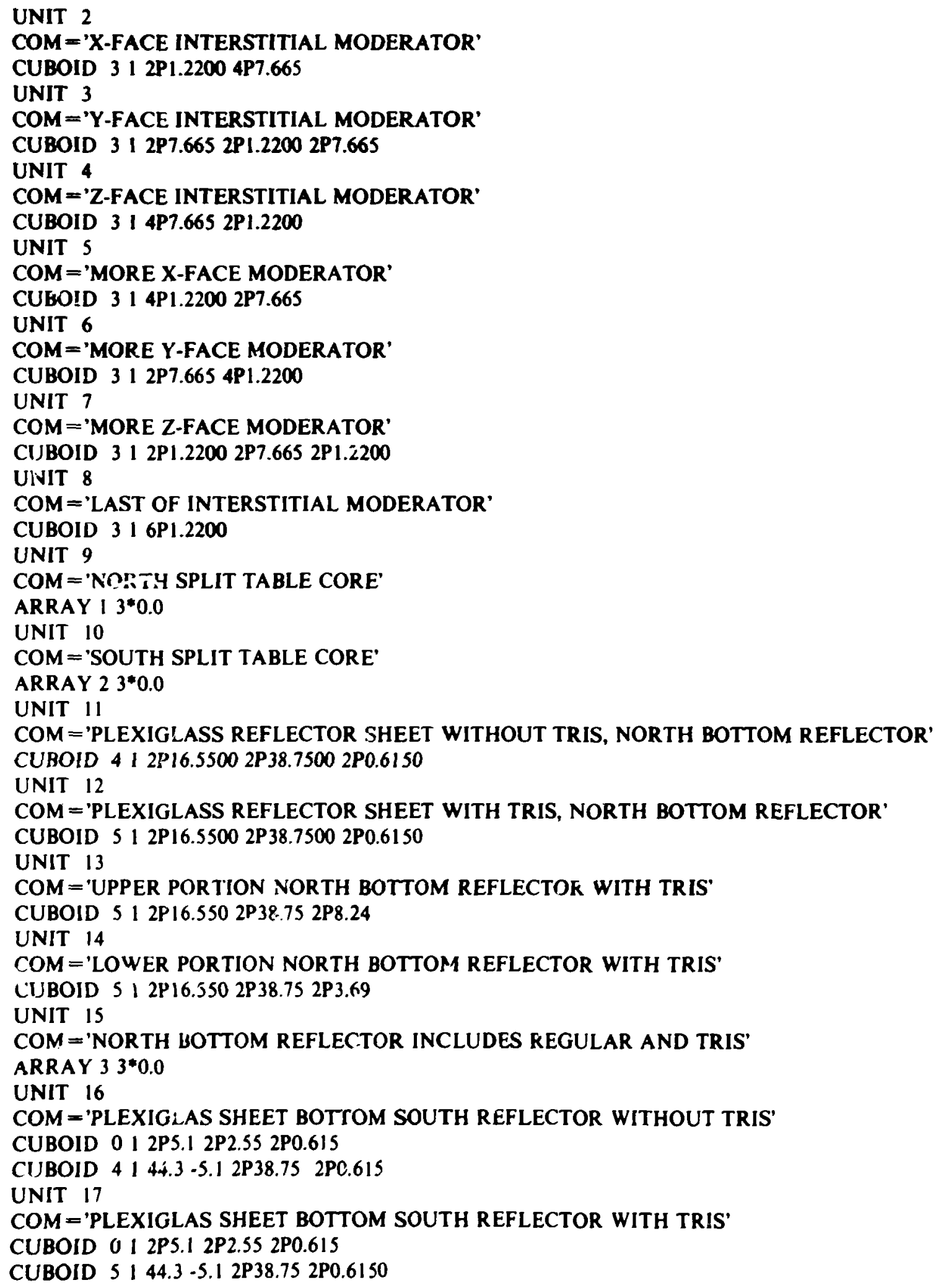




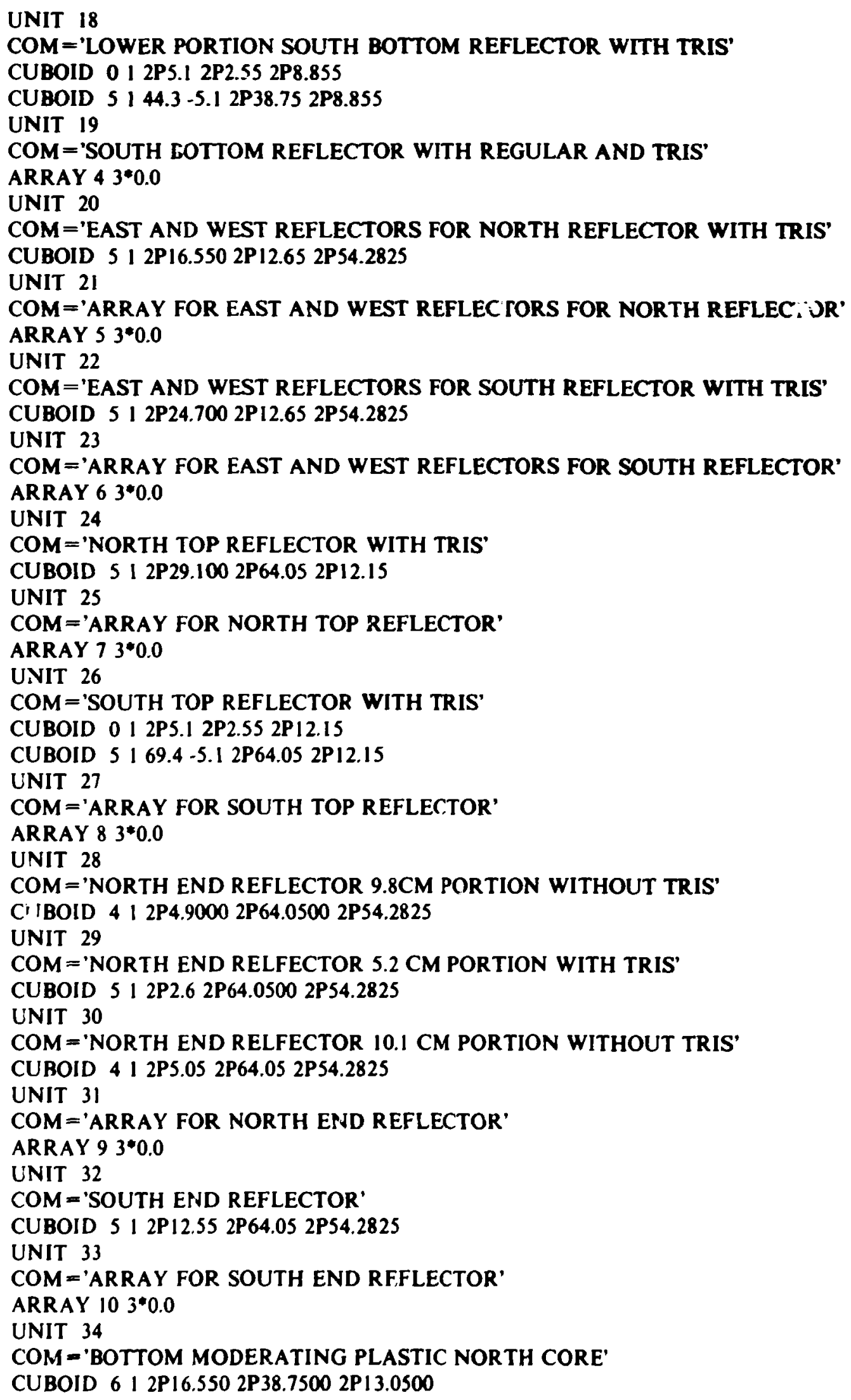




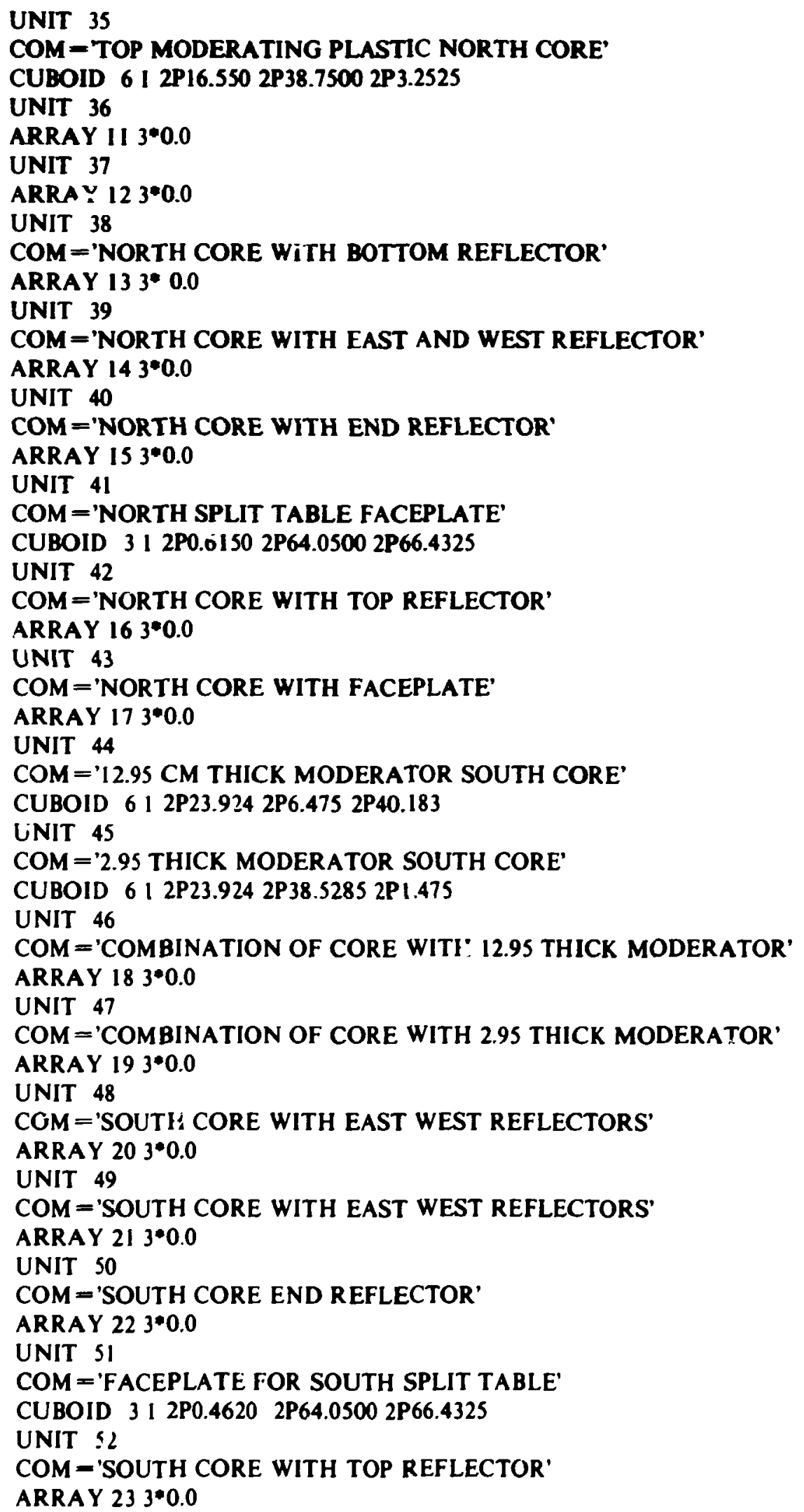




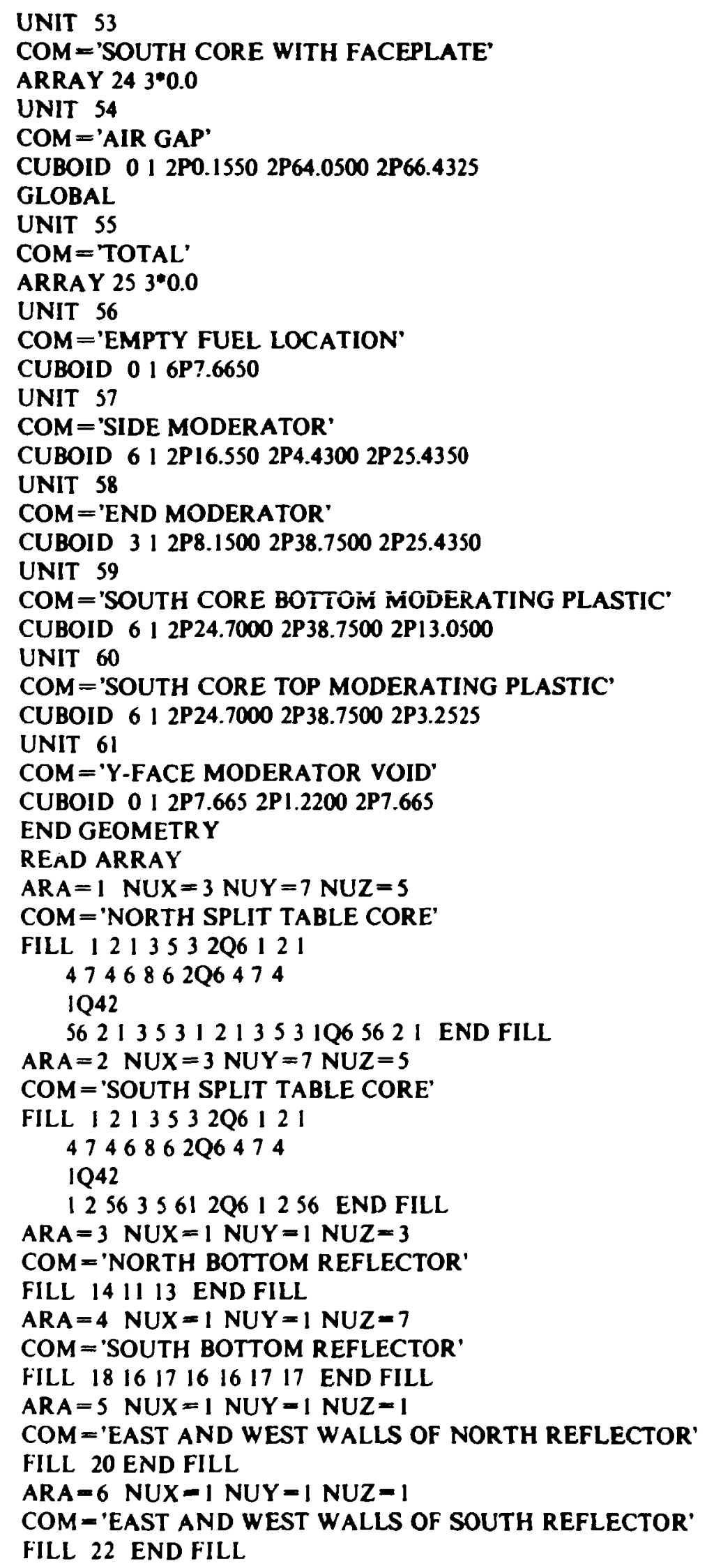









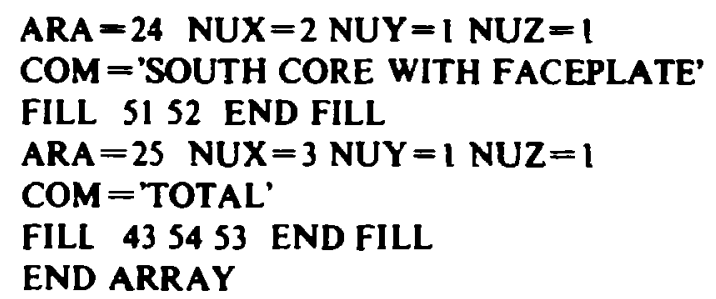

READ PLOT TIL='XZ SLICE OF RFPI S! ‘OWING MATERIAL REGIONS'

$\mathrm{XUL}=-2 \quad \mathrm{YUL}=32.3 \mathrm{ZUL}=136$

$X L R=137$ YLR $=32.3$ ZLR $=-2$

$U A X=1 \quad W D N=-1$ NAX $=130 \quad \mathrm{NCH}={ }^{\prime} 0123456^{\prime}$ END

TTL $=$ 'YZ SLICE OF NORTH CORE SECOND ROW'

$\mathrm{XUL}=28 \quad \mathrm{YUL}=-2 \quad \mathrm{ZUL}=136$

$X L R=\quad Y L R=136 Z L R=-2$

VAX $=\quad W D N=-1$ NAX $=130 \quad \mathrm{NCH}=0123456^{\prime}$ END

$T T L=~ Z Z$ SLICE OF SOUTH CORE FIRST ROW'

$\mathrm{XUL}=62 \quad \mathrm{YUL}=-2 \quad \mathrm{ZUL}=136$

$X L R=62 \quad Y L R=136 \quad Z L R=-2$

VAX $=1$ WDN $=-1$ NAX $=130 \quad \mathrm{NCH}={ }^{\prime} 0123456$ 'END

TTL $=$ 'TOP VIEW OF SOURCE HOLE'

$X U L=-2$ YUL $=136 \mathrm{ZUL}=125$

$X L R=136 \quad Y L R=-2 Z L R=125$

$U A X=1$ VDN $=-1$ NAX $=130 \mathrm{NCH}={ }^{\prime} 0123456$ '

END PLOT

END DATA

END

Case 42

//JOBCARD

// EXEC SPDASCR

T.GEEOOOOO.RSTI.HSNRCH.RFP2

//* PREVIOUS TWO LINES CLEAR T.GEE00000.RSTI.HSNRCH.RFP2 SO

$/ / /^{*}$ A RESTART FILE CAN BE WRITTEN ON UNIT 30 IN THIS FILE

//MIKE EXEC Y12CSG,REGION.GO $=1024 \mathrm{~K}$

$/ /$ FT84F00I DD DSN = T.GEE00000.HSNRCH1,DISP = SHR

//FT30F001 DD DSN=T.GEE00000.RST1.HSNRCH.RFP2,UNIT = SPDA,

// $\mathrm{SPACE}=(T R K,(20,10)), \mathrm{DCB}=(\mathrm{RECFM}=\mathrm{VBS}, \mathrm{LRECL}=\mathrm{X}, \mathrm{BLKSIZE}=3156, \mathrm{BUFL}=4088)$,

$/ /$ DISP $=($, CATLG $)$

$/ /$ GO.SYSIN DD *

$=$ CSAS25

ROCKY FLATS CRITICALS NUREG/CR-1071 EXPERIMENT NUMBER 2 (HANSEN-ROACH) 218GROUPNDF4 LATTICECELL

HAVEREDEFINED

U3O8 I S.4078E-1 293.0 922340.0392235 4.46 922360.0892238 95.43 E,ND

H2O I 8.9514E-2 END

ARBM-BAGGIE $1.03000100114 .01601284 .980161 .2011 .9134 E-2$ E' ID

ARBM-AL1100 $1.030011302799 .18260000 .5290000 .229 .5390 E-1$

END 
ARBM-TAPE(VINYL) 1.0700010015 .92601245 .91801610 .8217000

$25.73200406 .9220001 .6820001 .121 .1115 E-2$ END

ARBM-TAPE(MYLAR) 1.0300010016 .83601265 .50801627 .022 1.7491E-2 END

ARBM-MODERATOR $1.185300010017 .83601259 .49801 \leqslant 32.483$ END

ARBM-PLEX(REG) 1.0300010017 .84601259 .59801632 .234

1.1773 END

ARBM-PLEX(PAPER) 1.0300010016 .48601242 .17801649 .54

3.7534E-3 END

ARBM-PLEX(GLUE) 1.03000100111 .67601286 .2980161 .204

I.1648E-3 END

ARBM-PLEX(TRIS) 1.0800110017 .16601252 .0370140 .16801629 .82

150311.02170001 .81350794 .260350812 .84051 .2757 END

ARBM-PLEX(PAPER) 1.0300010016 .48601242 .17801649 .55

3.7534E-3 END

ARBM-PLEX(GLUE) 1.03000100111 .67601286 .2980161 .205

1.1648E-3 END

ARBM-FILLER 1.185300010017 .83601259 .49801632 .486 .89 END

END COMP

SPHTRIANGP 19.946218 .58571318 .95792 END

ROCKY FLATS CRITICALS NUREG/CR-1071 EXPERIMENT NUMBER 2 (HANSEN-ROACH)

READ PARM RUN $=$ YES NPG $=500$ RES $=103$ WRS $=30$

END PARM

READ GEOM

UNIT 1

COM='FUEL BOX 15.28 CM ON A SIDE WITH .15 CM WALLS .05CM STACKING VOID'

CUBOID $116 \mathrm{P} 7.49$

CUBOID $216 \mathrm{P} 7.64$

CUBOID 016 P7.6650

UNIT 2

COM ='X-FACE INTERSTITIAL MODERATOR'

CUBOID $312 \mathrm{PI} .2200$ 4P7.665

UNIT 3

COM = 'Y-FACE INTERSTITIAL MODERATOR'

CUBOID 312 2P7.665 2P1.2200 2P7.665

UNIT 4

COM ='Z-FACE INTERSTITIAL MODERATOR'

CUBOID 314 P 7.665 2P1.2200

UNIT 5

COM='MOP.E X-FACE MODERATOR'

CUBOID 314 P 1.2200 2P7.665

UN T 6

'OM = 'MORE Y-FACE MODERATOR'

CUBOID $312 \mathrm{P} 7.665$ 4PI.2200

UNIT 7

COM ='MORE Z-FACE MODERATOR'

CUBOID $312 \mathrm{P} 1.22002 \mathrm{P} 7.6652 \mathrm{P} 1.2200$

UNIT 8

COM ='LAST OF INTERSTITIAL MODERATOR'

CUBOID $316 \mathrm{PP} 1.2200$ 
UNIT 9

COM ='NORTH SPLIT TABLE CORE'

ARRAY $13 * 0.0$

UNIT 10

COM ='SOUTH SPLIT TABLE CORE'

ARRAY $23^{*} 0.0$

UNIT 11

COM ='PLEXIGLASS REFLECTOR SHEET WITHOUT TRIS, NORTH BOTTOM REFLECTOR'

CUBOID 412 P16.5500 2P38.7500 2P0.6150

UNIT 12

COM='PLEXIGLASS REFLECTOR SHEET WITH TRIS, NORTH BOTTOM REFLECTOR'

CUBOID 5 I 2P16.5500 2P38.7500 2P0.6!50

UNIT 13

COM = 'UPPER PORTION NORTH BOTTOM REFLECTOR WITH TRIS'

CUBOID $512 \mathrm{P} 16.5502 \mathrm{P} 38.752 \mathrm{P} 8.24$

UNIT 14

COM $=$ 'LOWER PORTION NORTH BOTTOM REFLECTOR WITH TRIS'

CUBOID 5 I 2P16.550 2P38.75 2P3.69

UNIT 15

COM ='NORTH BOTTOM REFLECTOR INCLUDES REGULAR AND TRIS'

ARRAY $33 * 0.0$

UNIT 16

COM='PLEXIGLAS SHEET BOTTOM SOUTH REFLECTOR WITHOUT TRIS'

CUBOID $012 \mathrm{P} 5.1$ 2P2.55 2P0.6150

CUBOID 4 I $44.3-5.12$ 2P38.75 2P0.615

UNIT 17

COM ='PLEXIGLAS SHEET BOTTOM SOUTH REFLECTOR WITH TRIS'

CUBOID 0 I 2P5.1 2P2.55 2P0.6150

CUBOID 5 I $44.3-5.12 \mathrm{P} 38.752 \mathrm{P} 0.6150$

UNIT 18

COM = 'LOWER PORTION SOUTH BOTTOM REFLECTOR WITH TRIS'

CUBOID 012 2P5.1 2P2.55 2P8.855

CUBOID 5 I $44.3-5.12$ P 38.75 2P8.855

UNIT 19

COM = 'SOUTH BOTTOM REFLECTOR WITH REGULAR AND TRIS'

ARRAY $43^{*} 0.0$

UNIT 20

COM ='EAST AND WEST REFLECTORS FOR NORTH REFLECTOR WITH TRIS'

CUBOID 5 I 2 P 16.550 2P12.65 2P54.2825

UNIT 21

COM = 'ARRAY FOR EAST AND WEST REFLECTORS FOR NORTH REFLECTOR'

ARRAY $53^{*} 0.0$

UNIT 22

COM ='EAST AND WEST REFLECTORS FOR SOUTH REFLECTOR WITH TRIS'

CUBOID 512 P24.700 2P12.65 2P54.2825

UNIT 23

COM = 'ARRAY FOR EAST AND WEST REFLECTORS FOR SOUTH REFLECTOR'

ARRAY $63^{*} 0.0$

UNIT 24

COM = 'NOR ?H TOP REFLECTOR WITH TRIS'

CUBOID 51 2P29.100 2P64.05 2P12.15 


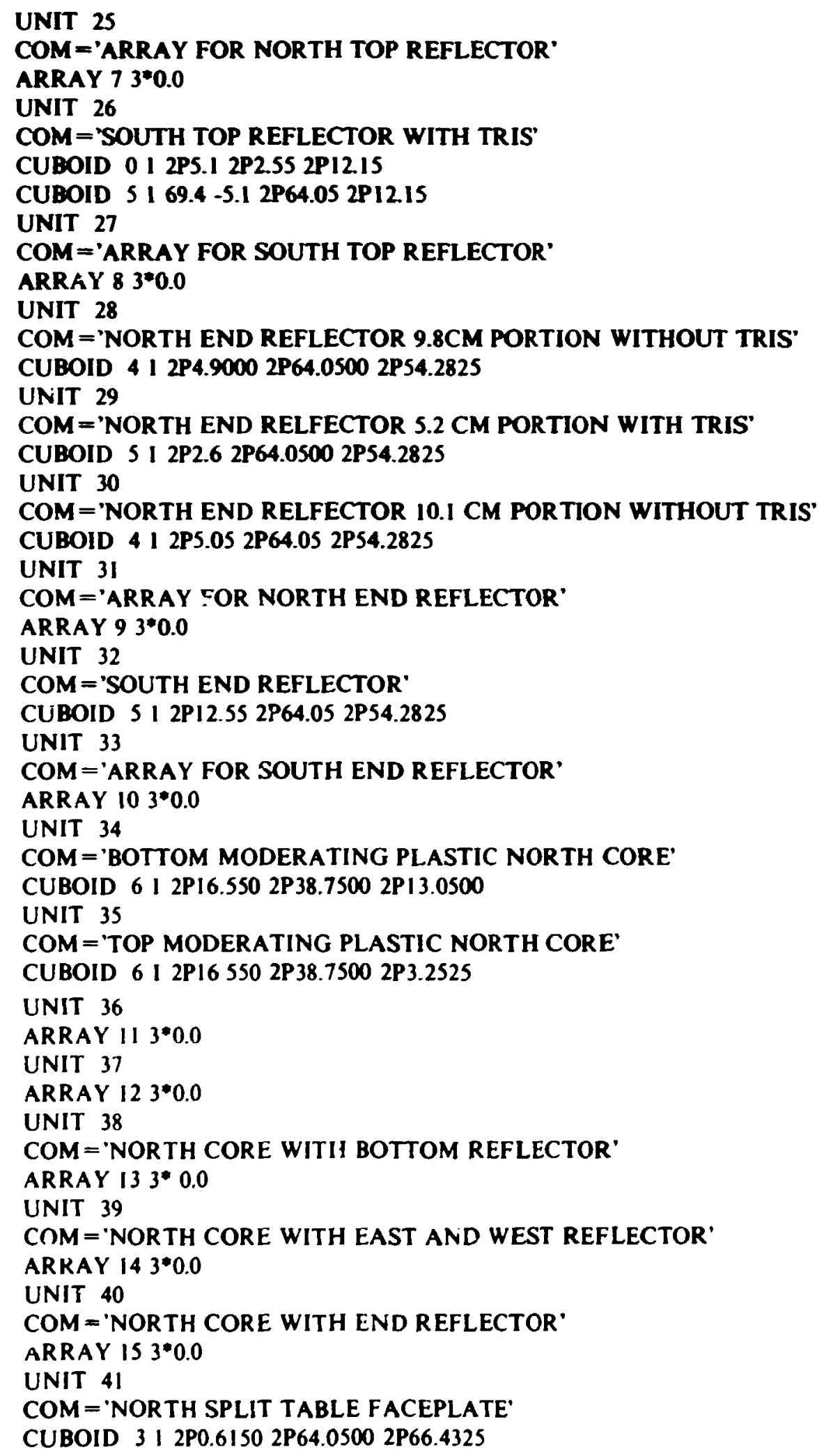




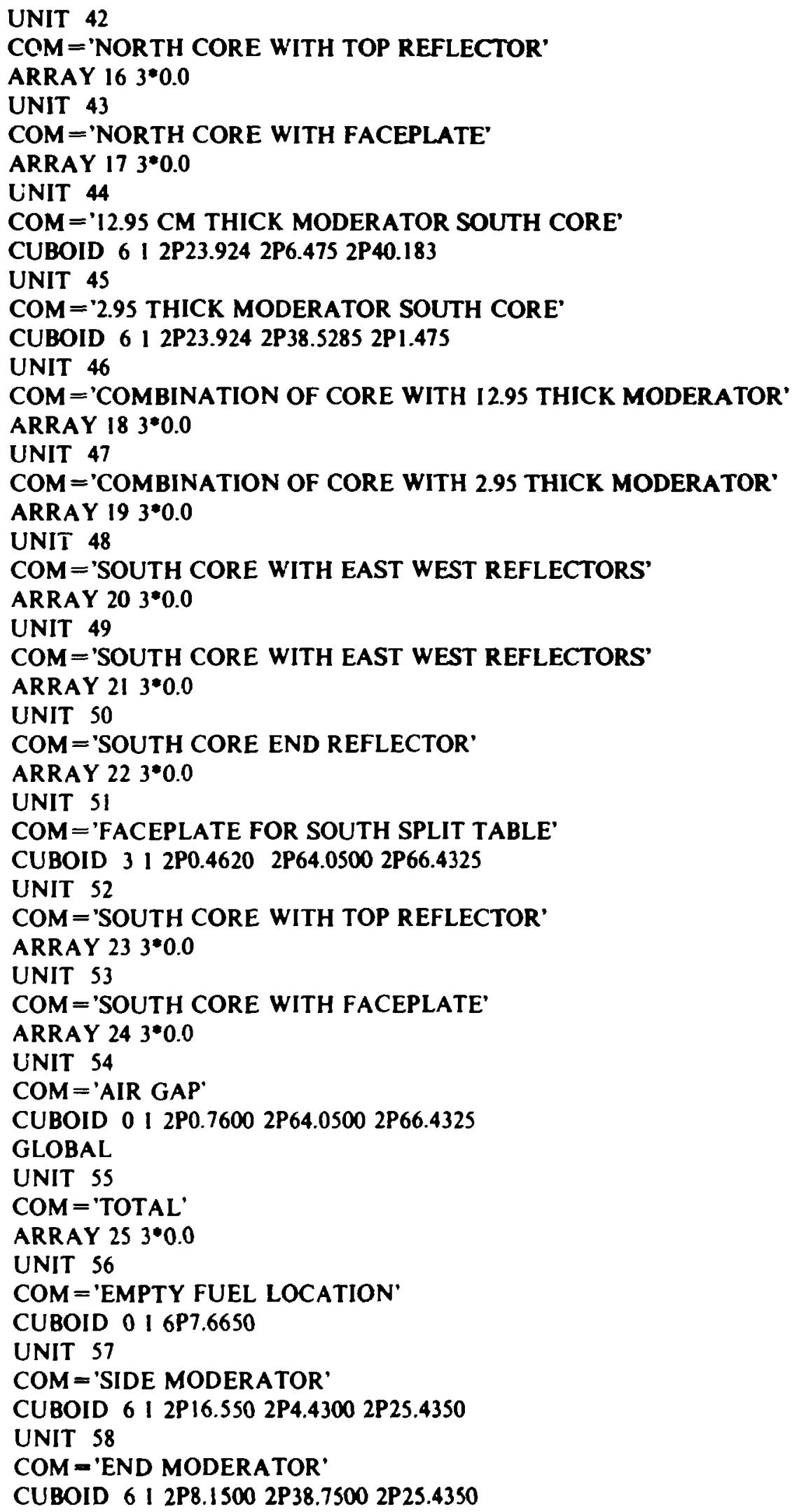


UNIT 59

COM = 'SOUTH CORE BOTTOM MODERATING PLASTIC'

CUBOID $612 \mathrm{P} 24.70002 \mathrm{P} 38.75002 \mathrm{P} 13.0500$

UNIT 60

COM = 'SOUTH CORE TOP MODERATING PLASTIC'

CUBOID 61 2P24.7000 2P38.7500 2P3.2525

UNIT 61

COM ='Y-FACE MODERATOR VOID'

CUBOID $012 \mathrm{P} 7.665$ 2P1.2200 2P7.665

END GEOMETRY

READ ARRAY

$A R A=1 \quad N U X=3 \quad N U Y=7 \quad N U Z=5$

COM $=$ 'NORTH SPLIT TABLE CORE'

FILL $1213532 Q 6121$

$4746862 Q 6474$

$1 Q 42$

$56213531213531 Q 65621$ END FILL

$A R A=2$ NUX $=3$ NUY $=7$ NUZ $=5$

COM ='SOUTH SPLIT TABLE CORE'

FILL $1213532 Q 6121$

474686206474

$1 \mathrm{Q} 42$

1256353121353125635611256 END FILL

$A R A=3 \quad N U X=1$ NUY $=1$ NUZ $=3$

COM $=$ 'NORTH BOTTOM REFLECTOR'

FILL 141113 END FILL

$A R A=4 \quad N U X=1$ NUY $=1$ NUZ $=$ ?

COM ='SOUTH BOTTOM REFLECTOR'

FILL 18161716161717 END FILL

$A R A=5 \quad N U X=1$ NUY $=1$ NUZ $=1$

COM='EAST AND WEST WALLS OF NORTH REFLECTOR'

FILL 20 END FILL

ARA $=6 \quad$ NUX $=1$ NUY $=1$ NUZ $=1$

COM $=$ 'EAST AND WEST WALLS OF SOUTH REFLECTOR'

FILL 22 END FILL

$A R A=7 \quad N U X=1$ NUY $=1$ NUZ $=1$

COM = 'ARRAY FOR NORTH TOP REFLECTOR'

FILL 24 END FILL

$A R A=8 \quad N U X=1$ NUY $=1 \quad N U Z=1$

COM $=$ 'ARRAY FOR SOUTH TOP REFLECTOR'

FILL 26 END FILL

$A R A_{A}=9$ NUX $=3$ NUY $=1$ NUZ $=1$

COM = 'ARRAY FOR NORTH END REFLECTOR'

FILL 282930 END FILL

$A R A=10 \quad N U X=1$ NUY $=1 \quad N U Z=1$

COM ='ARRAY FOR SOUTH END REFLECTOR'

FILL 32 END FILL

$A R A=11 \quad N U X=1$ NUY $=2 \quad N U Z=1$

COM = 'COMBINARION OF CORE WITH SIDE MODERATOR'

FILL 957 END FILL

$A R A=12$ NUX $=1$ NUY $=1 N U Z=3$

COM = 'COMBIN.ATION OF PREVIOUS ARRAY WITH TOP AND BOTTOM MODER.ATOR'

FILL 343635 END FILL 


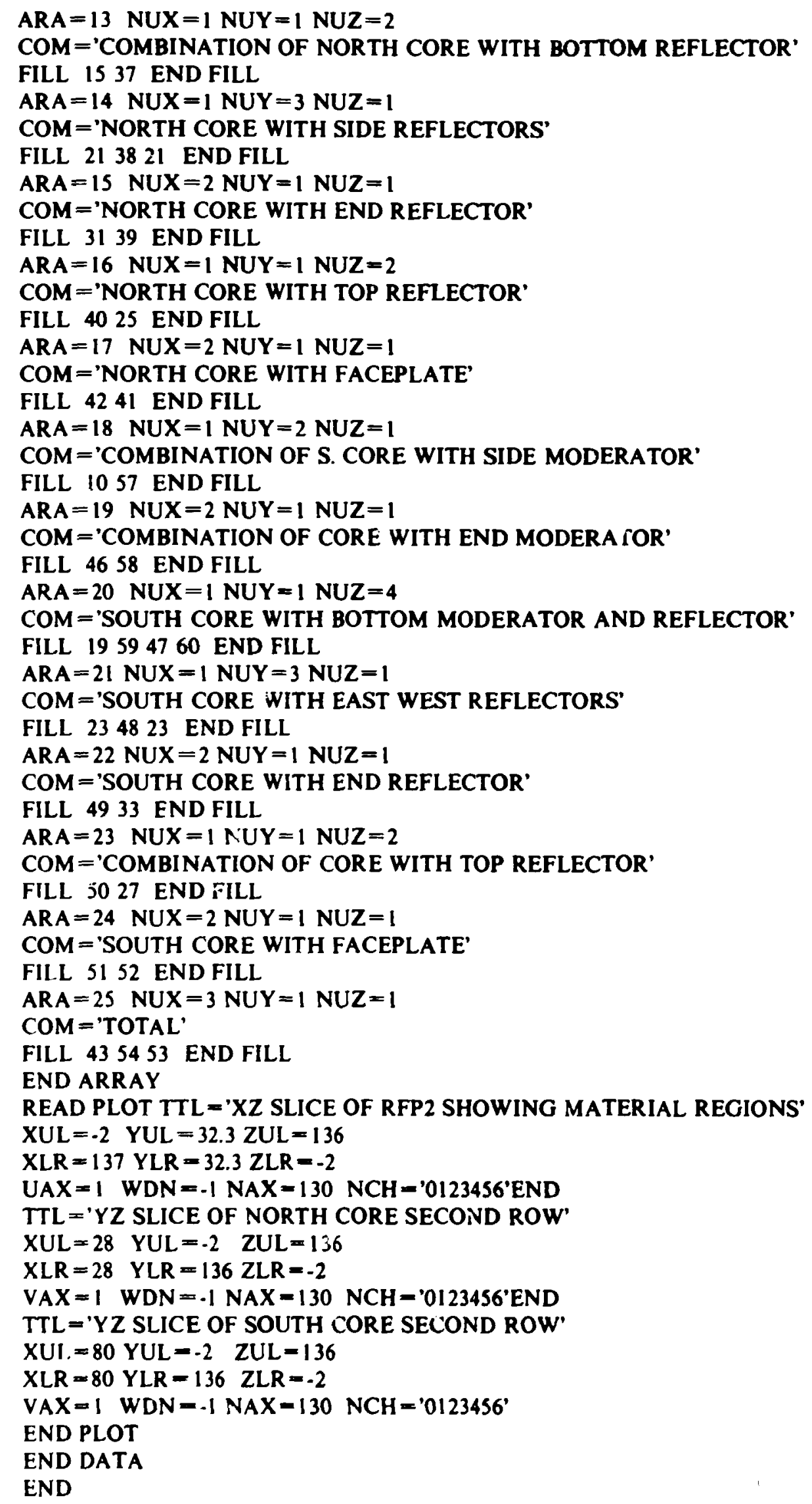


Case 43

//JOBCARD

// EXEC SPDASCR

T.GEEOOOOO.RSTI.HSNRCH.RFP3

//* PREVIOUS TWO LINES CLEAR T.GEE00000.RSTI.HSNRCH.RFP3 SO

$/ / *$ A RESTART FILE CAN BE WRITTEN ON UNIT 30 IN THIS FILE

//MIKE EXEC Y12CSG,REGION.GO $=1024 \mathrm{~K}$

//FT84F001 DD DSN=T.GEE00000.HSNRCH1,DISP=SHR

//FT30F001 DD DSN = T.GEE00000.RST1.HSNRCH.RFP3,UNIT =SPDA,

// $\operatorname{SPACE}=($ TRK,$(20,10)), \mathrm{DCB}=($ RECFM $=$ VBS,LRECL $=X, B L K S I Z E=3156, \mathrm{BUFL}=4088)$,

// DISP $=($,CATLG $)$

$/ /$ GO.SYSIN DD *

$=$ CSAS25

ROCKY FLATS CRITICALS NUREG/CR-1071 EXPERIMENT NUMBER 3 (HANSEN-ROACH) 218GROUPNDF4 LATTICECELL

HAVEREDEFINED

U3O8 1 5.4078E-1 293.0922340 .03922354 .46922360 .089223895 .43 END

H2O 1 8.9514E-2 END

ARBM-BAGGIE $1.03 \supset 00100114.01601284 .980161 .2011 .9134 E-2$

END

ARBM-AL1100 1.0 $30011302799.18260000 .5290000 .229 .5390 E-1$

END

ARBM-TAPE(VINYL) 1.0700010015 .92601245 .91801610 .8217000

$25.73200406 .9220001 .6820001 .121 .1115 \mathrm{E}-2$ END

AF MM-TAPE(MYLAR) 1.0300010016 .83601265 .50801627 .022

1.7491E-2 END

AR BM-MODERATOR 1.185300010017 .83601259 .49801632 .483 END

ARBM-PLEX(REG) 1.0300010017 .84601259 .59801632 .234

1.1773 END

ARBM-PLEX(PAPER) 1.0300010016 .48601242 .17801649 .54

3.7534E-3 END

ARBM-PLEX(GLUE) 1.03000100111 .676012862980161 .204

1.1648E-3 END

ARBM-PLEX(TRIS) 1.0800110017 .16601252 .0370140 .16801629 .82

IS031 1.02170001 .81350794 .260350812 .84051 .2757 END

AR BM-PLEX(PAPER) 1.0300010016 .48601242 .17801649 .55

3.7534E-3 END

ARBM-PLEX(GLUE) 1.03000100111 .67601286 .2980161 .205

1.1648E-3 END

ARBM-FILLER 1.185300010017 .83601259 .49801632 .486 .70 END

END COMP

SPHTRIANGP 19.0018 .58571318 .95792 END

ROCKY FLATS CRITICALS NIJREG/CR-1071 EXPERIMENT NUMBER 3 (HANSEN-ROACH)

READ PARM $R U N=Y E S ~ N P G=500$ RES $=103 \mathrm{WRS}=30$

END PARM

READ GEOM

UNIT 1

COM ='FUEL BOX 15.28 CM ON A SIDE WITH .15 CM WALLS .05CM STACKING VOID'

CUBOID 116 P7.49

CUBOID $216 \mathrm{PP} 7.64$

CUBOID $016 \mathrm{P} 7.6650$ 


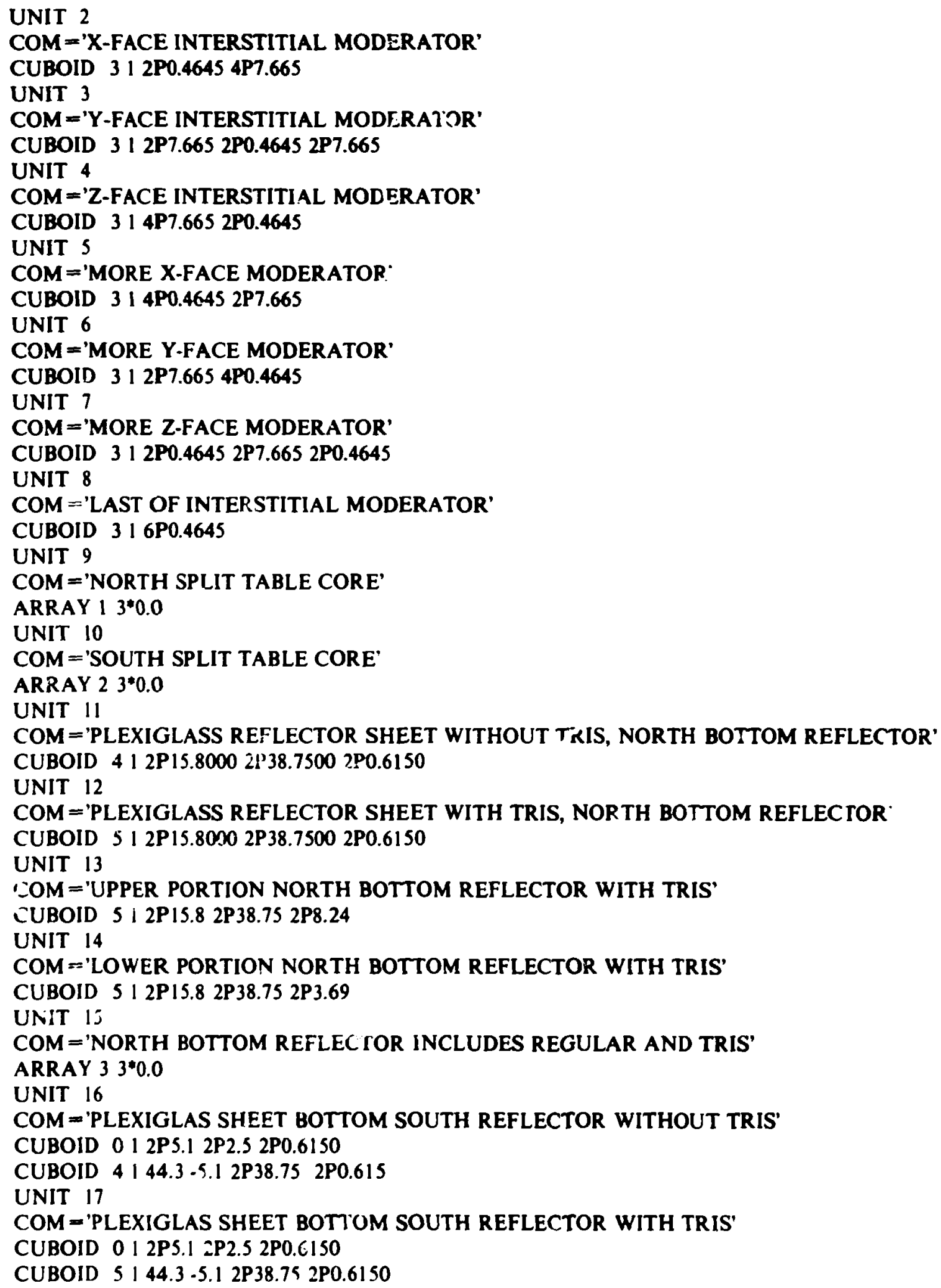


UNIT 18

COM = 'LOWER PORTION SOUTH BOTTOM REFLECTOR WITH TRIS'

CUBOID 0 I 2P5.1 2P2.5 2P8.855

CUBOID 5 | 44.3 -5.1 2P38.75 2P8.855

UNIT 19

COM ='SOUT H BOTTOM REFLECTOR WITH REGULAR AND TRIS'

ARRAY $43^{*} 0.0$

UNIT 20

COM ='EAST AND WEST REFLECTORS FOR NORTH REFLECTOR WITH TRIS'

CUBOID 512 P 15.8 2P12.65 2P54.2825

UNIT 21

COM ='ARRAY FOR EAST AND WEST REFLECTORS FOR NORTH REFLECTOR'

ARRAY $53^{* 0} 0.0$

UNIT 22

COM ='EAST AND WEST REFLECTORS FOR SOUTH REFLECTOR WITH TRIS'

CUBOID 51 2P24.700 2P12.65 2P54.2825

UNIT 23

COM ='ARRAY FOR EAST AND WEST REFLECTORS FOR SOUTH REFLECTOR'

ARRAY $63^{*} 0.0$

UNIT 24

COM $=$ 'NORTH TOP REFLECTOR WITH TRIS'

CUBOID $512 \mathrm{P} 28.352 \mathrm{P}^{\prime}+4.05$ 2P12.15

UNIT 25

COM ='ARRAY FOR NORTH TOP REFLECTOR'

ARRAY $73 * 0.0$

UNIT 26

COM = 'SOUTH TOP REFLECTOR WITH TRIS'

CUBOID $012 \mathrm{P} 5.12 \mathrm{P} 2.52 \mathrm{P} 12.15$

CUBOID 51 69.4 -5.1 2P64.05 2P12.15

UNIT 27

COM ='ARRAY FOR SOITH TOP REFLECTOR'

ARRAY $83 * 0.0$

INIT 28

COM $=$ 'NORTH END REFLECTOR 9.8C $:$ A PORTION WITIIOUT TRIS'

CUBOID $412 \mathrm{P} 4.90002 \mathrm{P} 64.0500$ 2P54.2825

UNIT 29

COM $=$ 'NORTI END RELFECTOR 5.2 'CM PORTION WITH TRIS'

CUEOID 5 , 2P2.6 2P64.0500 2P54.2825

UNIT 30

COM = 'NOR' H END RELFECTOR 10.1 CM PORTION WITHOUT TRIS'

CUBOID 41 ?P5.05 2P64.05 2P54.2825

UNIT 31

COM $=$ 'ARRAY FOR NORTH END REFLECTOR'

ARRAY $\rightarrow 3^{*} 0.0$

UNIT 32

COM = 'SOUTH END REF!.ECTOR'

CUBOID $5: 2 \mathrm{P} 12.55$ 2P64.05 2P54.2825

UIVIT 33

COM = 'ARRAY FOR SOUTH END REFLECTOR'

ARP.AY $103^{*} \mathrm{C} .0$ 
UNIT 34

COM $=$ '12.95 THICK MODERATING PLASTIC NORTH CORE'

CUBOID 61 2P15.7945 2P6.4750 2P40.1830

UNIT 35

COM $=$ '2.95 THICK MODEP.ATING PLASTIC NORTH CORE'

CUBOID 61 2P15.7945 2P38.5285 2P1.475

UNIT 36

ARRAY $113^{*} 0.0$

UNI i 37

ARRAY $123 * 0.0$

REPLICATE 010.00 .0110 .4430 .00 .15900 .01

UNIT 38

COM='NORTH CORE WITH BOTTOM REFLECTOR'

ARRAY $133^{*} 0.0$

UNIT 39

COM $=$ 'NORTH CORE WITH EAST AND WEST REFLECTOR'

ARRAY $143^{*} 0.0$

UNIT 40

COM ='NORTH CORE WITH END REFLECTOR'

ARRAY $153^{*} 0.0$

UNIT 41

COM ='NORTH SPLIT TABLE FACEPLATE'

CUBOID $312 \mathrm{P} 0.6150$ 2P64.0500 2P66.4325

UNIT 42

COM: : 'NORTH CORE WITH TOP REFLECTOR'

ARRAY $163^{*} 0.0$

UNIT 43

COM ='NORTH CORE WITH FACEPLATE'

ARRAY $173^{*} 0.0$

UNIT 44

COM $=$ ' 12.95 CM THICK MODERATOR SOUTH CORE'

CUBO1D 612 P23.924 2P6.475 2P40.183

UNIT 45

COM $=$ '2.95 THICK MODERATOR SOUTH CORE'

CUBOID 612 P23.924 2P38.5285 2P1.475

UNIT 46

COM $\approx$ 'COMBINATION OF CORE: WITH 12.95 THICK MODERATOR'

ARRAY $183^{*} 0.0$

UNIT 47

COM ='COMBINATION OF CORE W'ITH 2.95 THICK MODERATOR'

ARRAY $193^{*} 0.0$

REPLICATE 011.5520 .00 .44300 .00 .1590 .01

UNIT 48

COM = 'SOUTH CORE WITH EAST WEST REFLECTORS'

ARRAY $203^{*} 0.0$

UNIT 49

COM $=$ 'SOUTH CORE WITH EAST WEST REFLECTORS'

ARRAY $213^{*} 0.0$

UNIT 50

COM = 'SOUTH CORE END REFLECTOR'

ARRAY $223^{*} 0,0$ 
UNIT 51

COM ='FACEPLATE FOR SOUTH SPLIT TABLE'

CUBOID 312 2P0.4620 2P64.0500 2P66.4325

UNIT 52

COM = 'SOUTH CORE WITH TOP REFLECTOR'

ARRAY $2333^{*} 0.0$

UNIT 53

COM = 'SOUTH CORE WITH FACEPLATE'

ARRAY $243^{\circ} 0.0$

UNIT 54

COM ='AIR GAP'

CUBOID 012 2P0.5250 2P64.0500 2P66.4325

GLOBAL

UNIT 55

COM $=$ 'TOTAL'

ARRAY $253 * 0.0$

END GEOMETRY

READ ARRA Y

AR.A $=1 \quad$ NUX $=3$ NUY $=7$ NUZ $=9$

COM ='NORTH SPLIT TABLE CORE'

FILL $1213532 Q 6121$

$4746862 Q 6474$

$3 Q 42$

$1213532 Q 6$ I 2 I END FILL

$A R A=2$ NUX $=5$ NUY $=7$ NUZ $=9$

COM = 'SOUTH SPLIT TABLE CORE'

FILI. $12121353532 Q 1012121$

$47474686862 Q 1047474$

3 Q70

I $2121353532 Q 10|2| 2 \mid$ END FILL

$A R A=3$ NUX $=1$ NUY $=1 \quad$ NUZ $=3$

COM = 'NORTH BOTTOM REFLECTOR'

FILL 141113 END FILL

$A R A=4 \quad N U X=1 \quad$ NUY $=1 \quad$ NUZ $=7$

COM = 'SOUTH BOTTCM REFLECTOR'

FILL 18161716161717 END FILL

$A R A=5 \quad N U X=1 \quad$ NUY $=1 \quad$ NUZ $=1$

COM ='EAST AND WEST WALLS OF NORTH REFLECTOR'

FILL 20 END FILL

$A R A=6 \quad N U X=1 \quad N U Y=1 N U Z=1$

COM $=$ 'EAST AND WEST WALLS OF SOUTH REFLECTOR'

FILL 22 END FILL

$A R A=7 \quad N U X=1 \quad$ NUY $=1 \quad$ NUZ $=1$

COM = 'ARRAY FOR NORTH TOP REFLECTOR'

FILL 24 END FILL

$A R A=8 \quad N U X=1 \quad N U Y=1 \quad N U Z=1$

COM = 'ARRAY FOR SOUTH TOP REFLECTOR'

FILL 26 END FILL

$A R A=9 \quad N U X=3 \quad N U Y=1 \quad N U Z=1$

COM ='ARRAY FOR NORTH END REFLECTOR'

FILL 282930 END FILL 


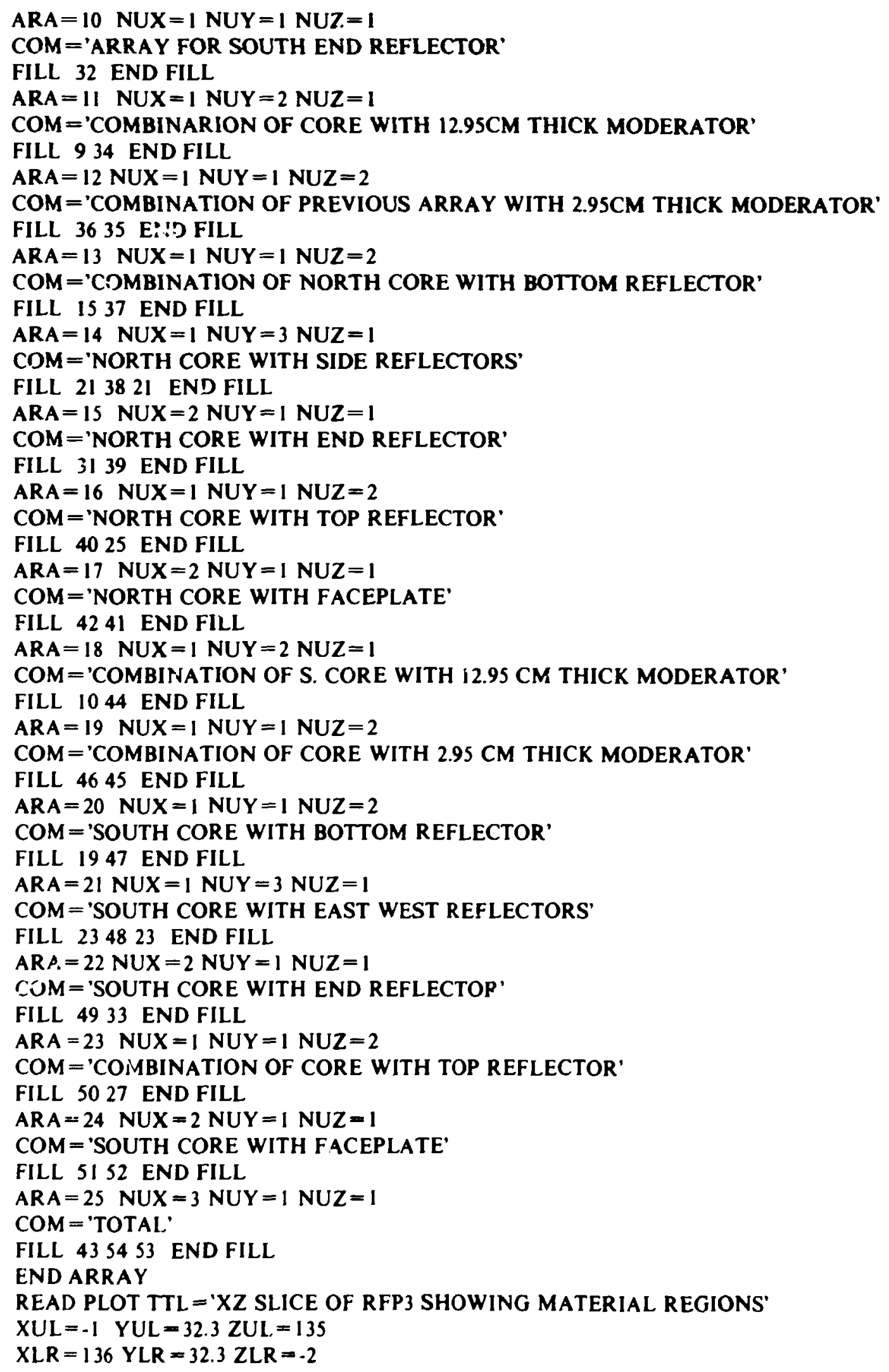




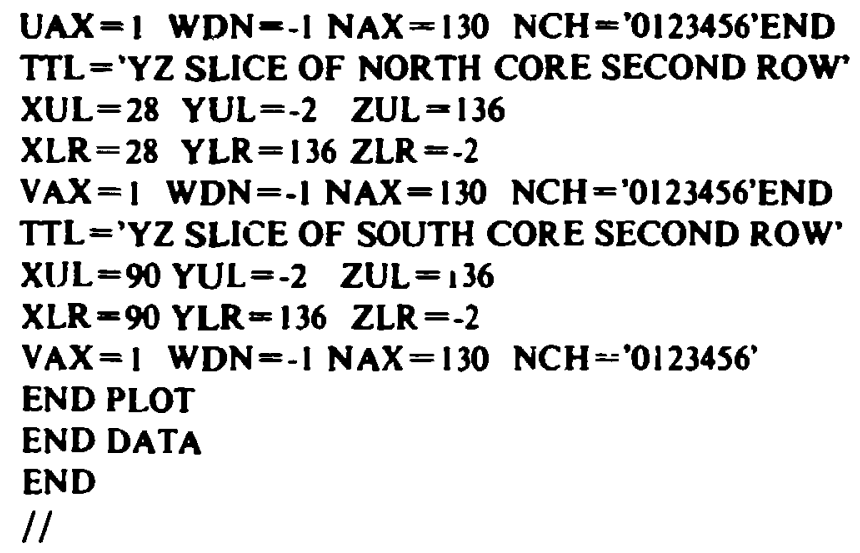




\section{APPENDIX D}

\section{ADDITONAL COMMENTS ABOUT THE ROCKY FLATS CRITICAL EXPERIMENTS}

The reports describing the critical experiments performed at the Rocky Flats Plant (Refs. 6-8) include many details about the experiments. The following discussion wiil explain why certain values were used in the input for the calculational model. For the first set of critical experiments performed at an $\mathrm{H}: \mathrm{U}$ of 0.77 , an effort was made to verify the given $\mathrm{H}: \mathrm{U}$ and calculate the $\mathrm{H}:{ }^{235} \mathrm{U}$ of the $\mathrm{fl}: \mathrm{l}$. The most accurate description of the hydrogenous contents of the fuel cubes is given in Ref. 14 and is shown in condensed form in Table D.I. The atomic weight of the fuel is calculated to be 237.9122 for the isotopic weight percents given in Ref. 14, Table V. On page 28 of the same document the average assay of the oxide is given as 0.8449 and the average weight of the oxide in a can is $15129.1 \mathrm{~g}$ (note: this also includes the weight of the initial moisture of $40.84 \mathrm{~g}$, so the true average weight of the oxide is $15 \mathrm{088.26}$ ), therefore, the mass of uranium in the oxide is $12748.1 \mathrm{~g}$.

The : $1: U$ ratio can be calculated with the above information in the following fashion:

$$
H: U=(m H / A(H)) /(m U / A(U)) .
$$

Where $\mathrm{mH}$ is the mass of hydrogen, $\mathrm{A}(\mathrm{H})$ is the atomic weight of hydrogen, $\mathrm{mU}$ is the mass of uranium, and $A(U)$ is the atomic weight of the uranium for the given isotopic content. This yields a H:U of 0.769 for the expeiments given in Ref. 6. A comment about this calculation is the true $H: U$ should not include the hydrogen contribution from the mylar tape and the vinyl tape because it is not intimately mixed with the fuel. thus reducing the $\mathrm{H}: \mathrm{U}$ to $\mathbf{0 . 7 6 0}$. The number densities calculated in SCALE give a $\mathrm{H}: \mathrm{U}$ of 0.787 which is well within the 0.06 uncertainty associated with the H:U calculated in Ref. 14. Similarly, the $\mathrm{H}:{ }^{235} \mathrm{U}$ ratio is calculated to be $\mathbf{1 7 . 0 2}$ and the ratio of the number densities in SCALE give $\mathrm{H}^{2}{ }^{235} \mathrm{U}$ equal to 17.4.

References 7 and 8 contain experiments performed at a higher $H: U$. The higher $H: U$ is obtained by injecting the same amount of water into each fuel cube. In Ref. 7 the experimenters inject an additional $224.0 \mathrm{~g}$ of water into each fuel cube, and in Ref. 8 they inject an additional $360.0 \mathrm{~g}$ of water into each cube. The $\mathrm{H}: \mathrm{U}$ values could not be reproduced from the data given in these individual reports. However, if the additional water injected in each experiment is added to the water in Table D.1 and the calculation of $\mathrm{H}: \mathrm{U}$ is performed, the $\mathrm{H}: \mathrm{U}$ values can re reproduced. Table D.2 compares the H:U values given in Refs. 6-8 with the values calculated from the information in the reports with and without the hydrogen contribution from the tape.

One of the problems confronted when modeling these experiments was localized absorption in the reflector. All of the experiments modeled used the same reflector shell with only minor changes due to the thickness of the interstitial moderator. At one point during the course of the experiments it was found that the reflector shells had been made from two types of Plexiglas, one type being regular Plexiglas and the other containing TRIS, a fire retardent chemical. It turns out that the Plexiglas containing TRIS has an increased absorption cross section due to chlorine and broraine contained in the TRIS. An analysis of the reflector shells indicated that nearly $80 \%$ of the Plexiglas in the retlector contained TRIS. Figure D.1 is a map showing the location v? non-TRIS Plexiglas in the north reflector and Fig. D.2 is a similar map of the south reflector. These maps were obtained from J. A. Bucholz at ORNL, who received them from I. Oh of the RFP while working on the design of some of the RFP critical experiments.

For the reader who is familiar with KENO IV, the computer input previously listed may seem a little confusing. The array-of-arrays option in KENO V.a is actually very simple to use, but, if not properly documented, it can cause havoc. What is meant by documentation is that a comment is included about each unit (box type) describing its function and location in the model (e.g., top reflector north core means top portion of the north reflector). This is done to prevent confusion 
Table D.I Hydrogenous material in fuel at $\mathrm{H} / \mathrm{U}=\mathbf{0 . 7 7}$

\begin{tabular}{lccc}
\hline \multicolumn{1}{c}{ Materal } & $\begin{array}{c}\text { Weight } \\
\text { (grams) }\end{array}$ & $\begin{array}{c}\text { Weight percent } \\
\text { hydrogen }\end{array}$ & $\begin{array}{c}\text { Hydrogen } \\
\text { content (grams) }\end{array}$ \\
\hline $\mathrm{H}_{2} \mathrm{O}$ in $\mathrm{U}_{3} \mathrm{O}_{8}$ & 40.84 & 11.19 & 4.57 \\
$\mathrm{H}_{2} \mathrm{O}$ injected & 259.52 & 11.19 & 29.04 \\
Polyethelyne bags & 53.2 & 14.01 & 7.45 \\
Mylar tape & 4.0 & 6.83 & 0.27 \\
Vinyl tape & 3.0 & 5.92 & 0.18 \\
& Total hydrogen content per fuel cube & 41.51 \\
\hline
\end{tabular}

Table D.2 Comparison of H:U values

\begin{tabular}{lcccc}
\hline With Hydrogen from Tape & \multicolumn{3}{c}{ Without Hydrogen from Tape } \\
\hline $\begin{array}{l}\text { Ref. } \\
\text { H:U }\end{array}$ & $\begin{array}{c}\text { Calculated } \\
\text { H:U }\end{array}$ & $\begin{array}{c}\text { Calculated } \\
\text { H:U }\end{array}$ & $\begin{array}{c}\text { Calculated } \\
\text { H:235 }\end{array}$ & $\begin{array}{c}\text { SCALE } \\
\text { H:235 }\end{array}$ \\
\hline 0.77 & $\mathbf{0 . 7 7}$ & $\mathbf{0 . 7 6}$ & 17.02 & 17.4 \\
1.23 & 1.23 & 1.22 & 27.11 & 27.67 \\
2.03 & 1.98 & 1.97 & 43.63 & 44.15 \\
\hline
\end{tabular}


TOP

SHELL

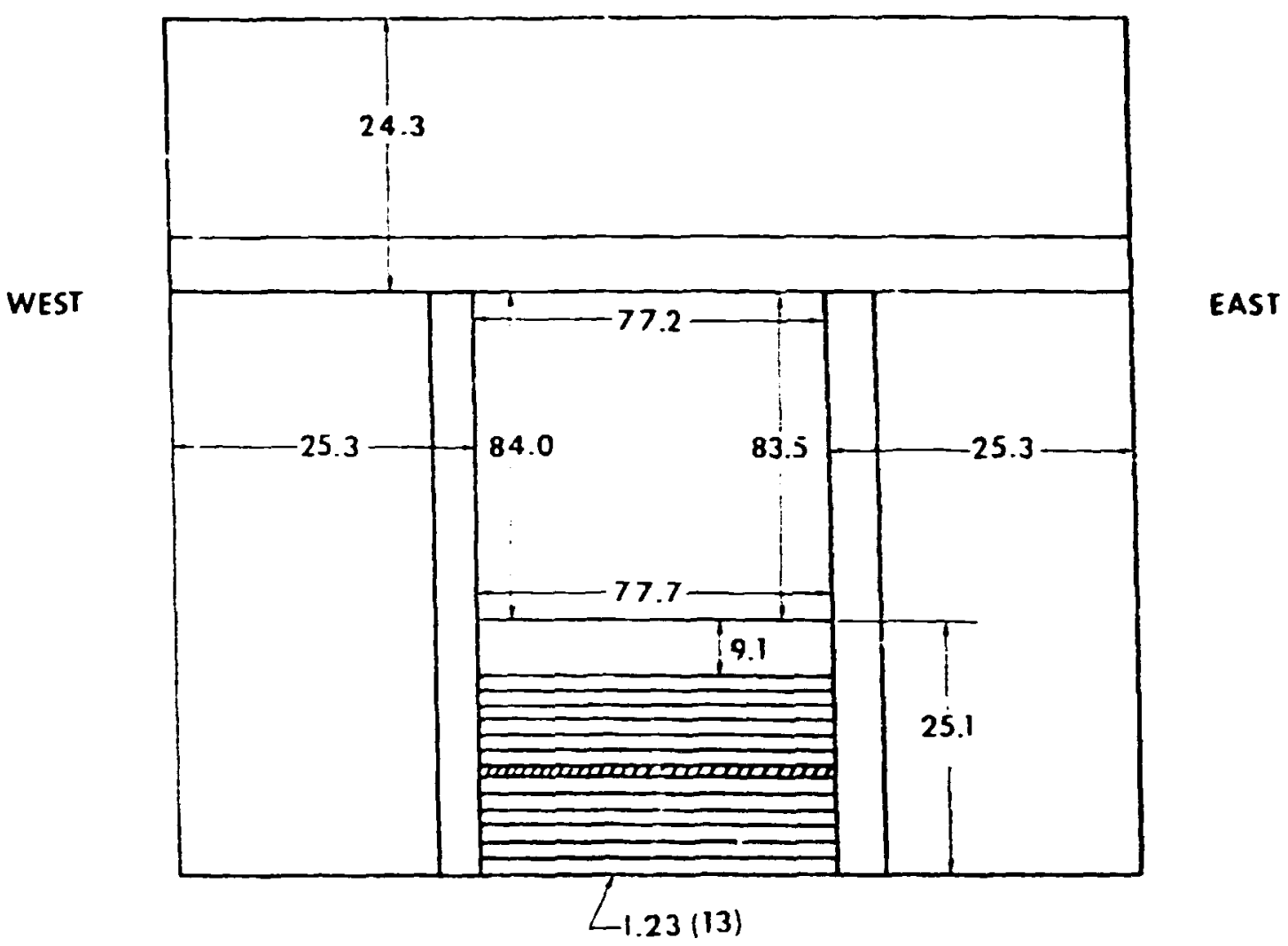

NORTH

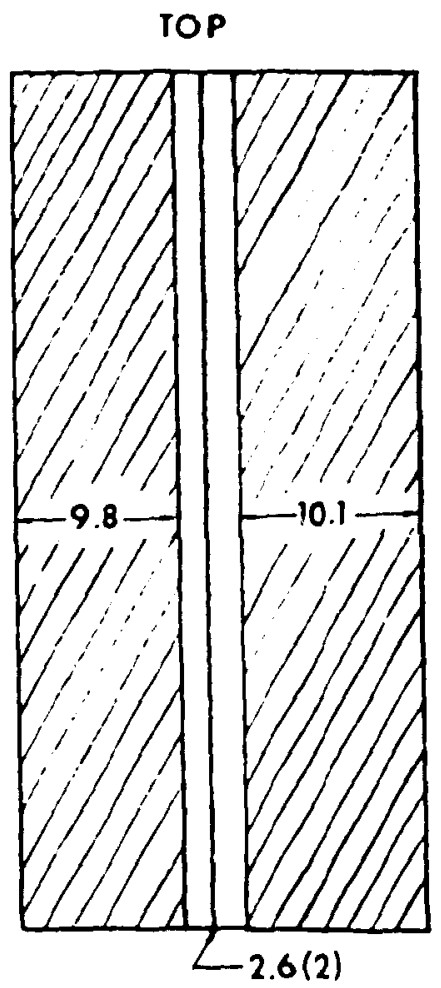

END REFLECTOR

SOUTH

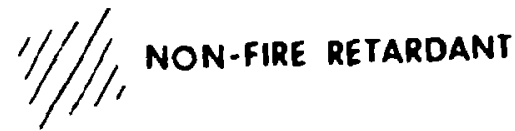

Fig. D.I North split table reflector map showing location of non-fire retardent Plexiglas 
TOP



TOP

NORTH
SHELL

WEST

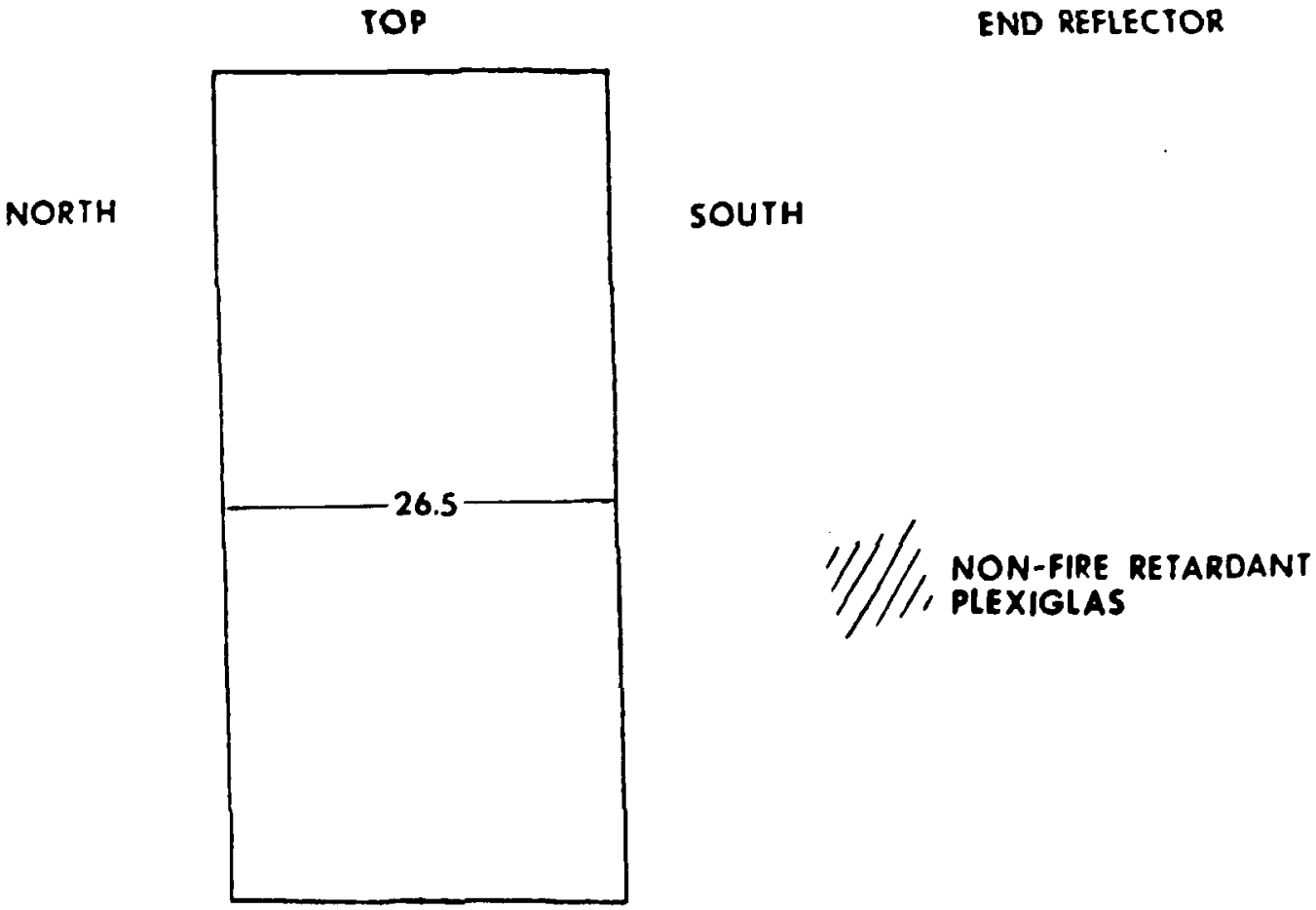

Fig. D. 2 South split table reflector map showing location of non-fire retardent Plexiglas 


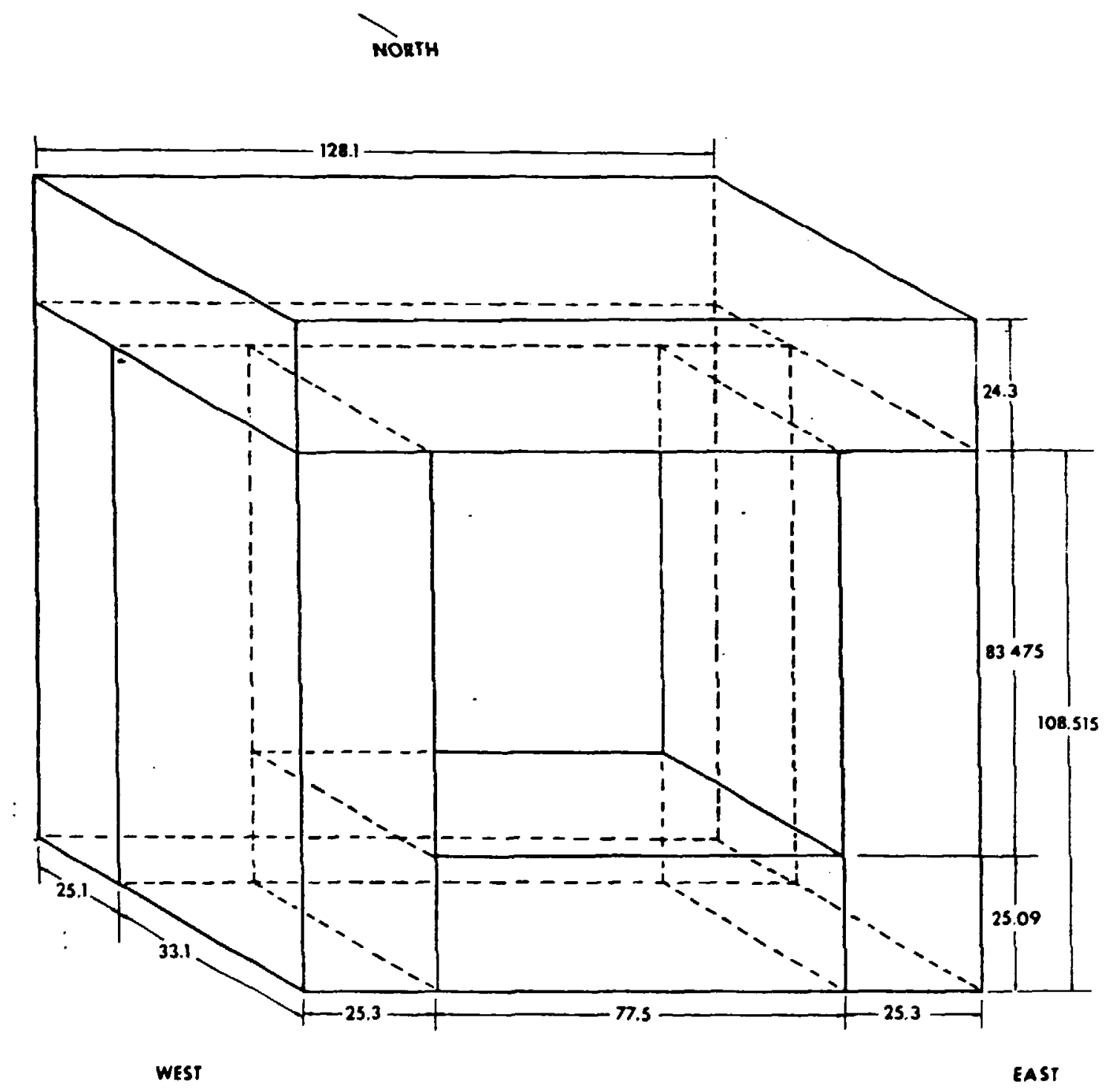

rig. D.3 Dimensions of north split table reflector used in computer models 


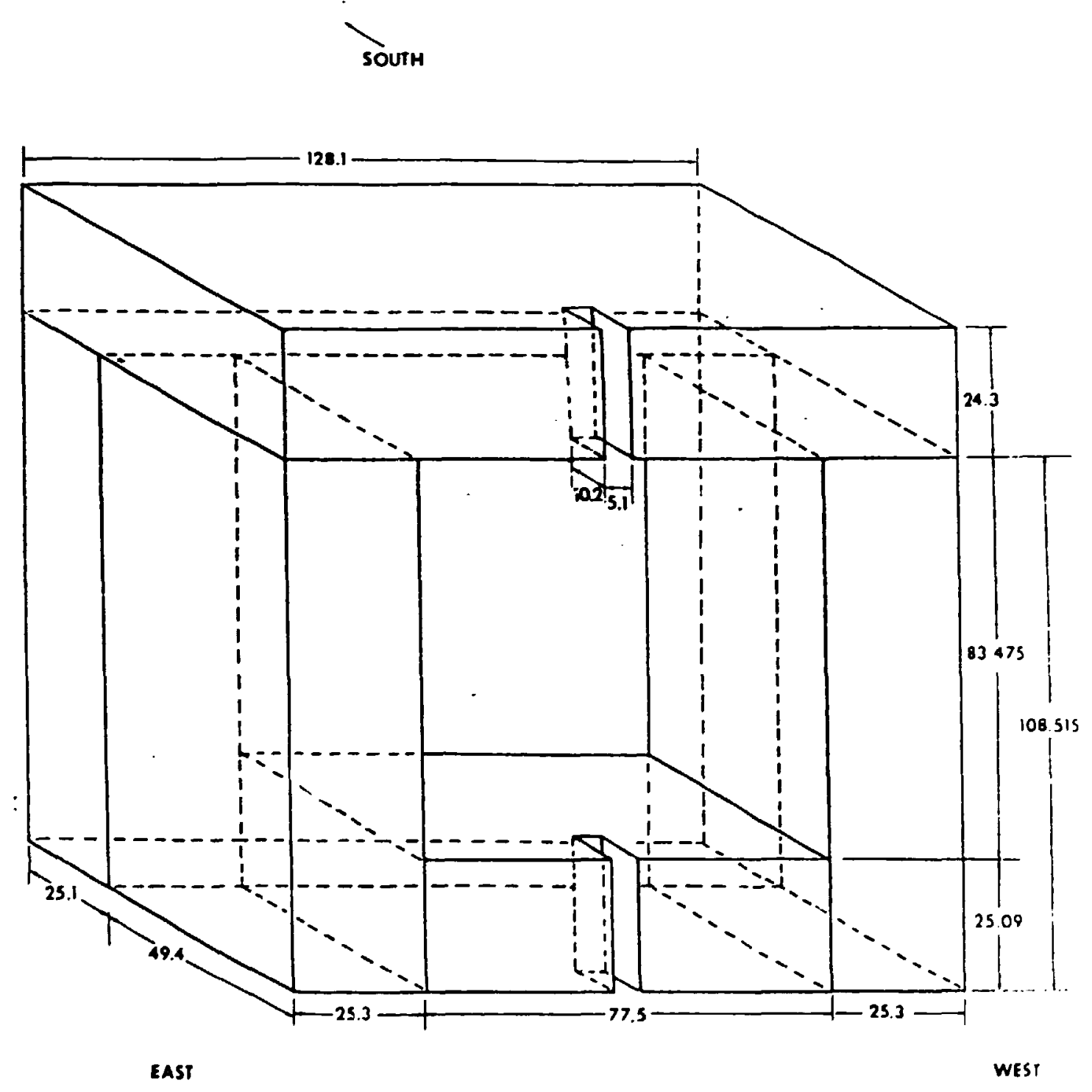

Fig. D.4 Dimensions of south split table reflector used in computer models 
when all of the pieces of the model are assembled in the READ ARRAY portion of the input. $\mathrm{Fi}_{\mathrm{i}}$-re D.3 shows the north reflector shell for undermoderated experiments (the thickness of the interstitial moderator between fuei cubes in the north-south direction will effect the nuith-south dimension of the reflector shell), and Fig. D.4 shows the south reflector shell for the same type of experiment. 


\section{APPENDIX E \\ CALCULATION OF LOWER TOLERANCE LIMITS}

The lower tolerance limits associated with the equations given in Section 6 were derived from an article in Ref. 11, pp. 207-9. This article is a query about one-sided tolerance bands such that a portion of the population $P$ lies above the lower tolerance limit with confidence alpha for all $\mathbf{X}$ in a stated interval. In criticality safety this is the same type of relation that will give a sound statistical basis to the safety associated with a calculation.

To illustrate the method used in this validation effort, we use the example in Ref. 11. We are looking for a tolerance limit about a curve based on the data from Ref. 11. These data are given in Table E.I. In this example the portion of the populaticn considered is $95 \%(P=.95)$ with a confidence level of $95 \%(\alpha=.95)$.

The lower tolerance limit is found by evaluating Equation 1 over

1) $Y=m^{*} X+B \cdot k * s$

the range of $X$. The first two terms in Equation 1 make up the simple linear model for the data in Table E.1. The last term, $k^{*} s$, is constant over the range of $X$, thereby generating a uniform tolerance band. The value of $k$ is to be determined and $s$ is the square root of the mean square error (root MSE). The coefficients $m$ and $B$ are estimated by the method of least squares and can be easily found using a suitable regression program. In this example we used the PROC GLM command available in SAS. ${ }^{12}$ From the SAS output the intercept (B) equals 51.41 , the slope (m) equals -10.32 , and the root MSE is equal to 0.095 .

The variable $k$ is defined to be:

$$
k=C+Z p^{*} \sqrt{\frac{N-2}{x^{2}}}
$$

where $C$ is a constant, $Z p$ is a standard normal deviate (e.g., a portion $P$ of the standard normal area is enclosed above $-Z p$ ), and $\chi^{2}$ is the $\chi^{2}$ for $N-2$ degrees of freedom and percentage point $=$ $\gamma_{2}$. To find the value of $C$, one must first find the values of $g, h, A$, and $\rho$. The reader is referred to Ref. 13, pp. 185-87 for the equations describing these variables. The values of $\mathrm{g}, \mathrm{h}, \mathrm{A}$, and $\mathrm{\rho}$ depend on the interval over which the tolerance band is to be determined; this example has end. points, $a=4.26, b=4.43$. These endpoints, used in the equations given in Ref. 13, yield $g=0.7299, h=0.3670, A-1.9888$, and $\rho=0.23$. One of several typographical errors found in Ref. 11 is the quantity $\Sigma X^{2}$, which should be $\Sigma(X i-X)^{2}$. This latter quantity is easily found by squaring the standard deviation and multiplying hy the number of samples minus one. In the example the value of this quantity is 0.0515 .

From the values of $A, \rho$, and $N-2$, the reader is referred to Ref. 13 to find a value of $D$ from the tables on pages 194-6. A new value used in the tables is $\gamma_{1}$, or 1 minus the confidence level (i.e., 1- $\alpha$ ) which, in this example, is 0.05 . By linear interpolation of Table III on page 194 we estimate a value of 2.47 for $D$. D is multiplied by $g$ to obtain $C$. $Z p$ is determined from the cumulative standard normal distribution according to $P$ set forth in the problem. In this case $P$ is selected to be $95 \%$ of the population, so we find the value of $Z_{p}$ in the table associated with an area of 0.05 which is -1.64 (the minus sign determines which side of the mean $\mathrm{Zn}$ is located). To find the value of the last variable, $\chi^{2}$, we look in a $\chi^{2}$ distribution table with $N-2$ degrees of freedom for the designated percentage point. This percentage point is found by solving the following expression for $\gamma_{2}$ : 


$$
\alpha=1-\frac{\gamma_{1}}{2}-\gamma_{2}
$$

Thus, $\alpha-0.95, \gamma_{1}=0.05$, so $\gamma_{2}=0.025$ and the value of $\chi^{2}(6,0.25)$ is 1.64 .

With the above data, we can now solve Equation 1 and find the line which defines the iower limit. Figure E.1 shows the data with the linear model and the lower tolerance limit for $P=0.95$ and $\alpha=0.95$. The derivation of the tolerance limits for the linear models described in the report are calculated similarly for $\mathbf{9 9 . 9 \%}$ of the population at a confidence level of $\mathbf{9 5 \%}$.

Table E.1 Example dat.1

\begin{tabular}{cc}
\hline$X$ & $Y$ \\
\hline 4.52 & 4.75 \\
4.49 & 5.00 \\
4.46 & 5.26 \\
4.43 & 5.68 \\
4.40 & 5.96 \\
4.36 & 6.56 \\
4.32 & 6.69 \\
4.27 & 7.28 \\
\hline
\end{tabular}




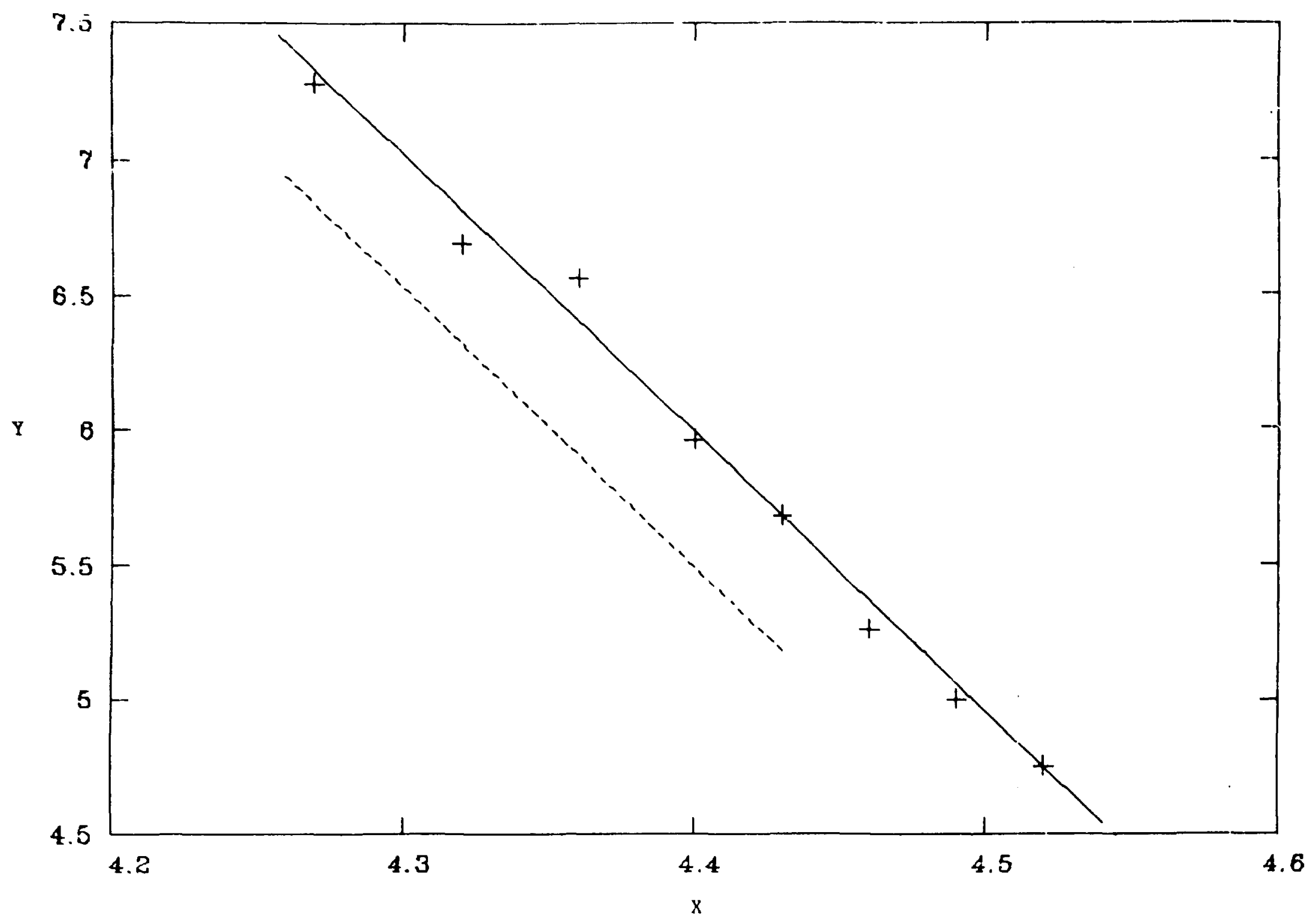

Fig. E.1 Plot of ex imple data with linear model and lower tolerance limit 


\section{INTERNAL DISTRIBUTION}

$\begin{aligned} \text { 1. } & \text { D. Bakerj } & 31 . & \text { L. M. Petrie } \\ 2 . & \text { Y. Y. Chan } & 32 . & \text { G. E. Ragan } \\ 3 . & \text { H. L. Dodds } & 33 . & \text { D. A. ReeJ } \\ 4-13 . & \text { H. R. Dyer } & 34 . & \text { J. E. Shoemaker } \\ 14-18 . & \text { M. E. Easter } & 35 . & \text { R. V. Stachowiak } \\ 19 . & \text { C. D. Ellis } & 36 . & \text { R. G. Taylor } \\ 20 . & \text { W. R. Golliher } & 37 . & \text { J. T. Thomas } \\ 21 . & \text { G. R. Handley } & 38 . & \text { R. M. Westfall } \\ 22 . & \text { C. M. Hopper } & 39 . & \text { G. E. Whitesides/R. P. Leinius/C\&TD Library } \\ 23 . & \text { J. C. Ingram } & 40 . & \text { K-25 CS Library } \\ 24 . & \text { T. A. Jokerst } & 41-43 . & \text { K-25 Plaut Library } \\ 25 . & \text { W. C. Jordan } & 44 . & \text { Central Research Library } \\ 26 . & \text { N. F. Landers } & 45 . & \text { Document Reference Section, Y-12 } \\ 27 . & \text { L. C. Masters } & 46-47 . & \text { Laboratory Records } \\ 28 . & \text { W. T. Mee } & 48 . & \text { ORNL Patent Section } \\ 29 . & \text { C. E. Newlon } & 49-50 . & \text { ORGDP Library } \\ 30 . & \text { C. V. Parks } & & \end{aligned}$

\section{EXTERNAL DISTRIBUTION}

51. Division of Engineering, Mathematies and Geosciences, DOE, Washington, DC 20545

52. Office of Assistant Mgr. for Energy Research and Development, DOE/ORO, Oak Ridge, TN 37830

53. T. Albert, Science Applications, Inc., Clearwater, FL

54. C. S. Barnette, Lawrence Livermore National Laboratory, P.O. Box 808, Livermore, CA 94550

55. G. H. Bidinger, Transportation Branch, Office of Nuclear Material Safety and Safeguards, Nuclear Regulatory Commission, P iS 396-SS, Washington, D.C. 20555

56. S. R. Bierman, Battelle-Pacific Northwest Labs, P.O. Box 999, Richland, WA 99352

57. C. Brown, Exxon Nuclear Idaho Co., Inc., Idaho Falls, ID

58. C. L. Brown, Criticality Engineering \& Analysis, Rockwell Hanford Operations, P.O. Box 800, Richland, WA 99352

59. J. S. Bullington, Savannah River Laboratory, Aiken, SC 29808

60. R. D. Carter, Rockwell Hanford Operations, P.O. Box 800. Richiand, WA 99352

61. M. Chandler, Savannah River Laboratory, Aiken, SC 29808

62. H. K. Clark, Savannah River Laboratory, Aiken, SC 29808

63. E. D. Clayton, Batte!le- ra 3cific Northwest Labs, P.O. Box 9y9, Richland, WA 99352

64. L. C. Dolan, Nationa' !.uad Co. of Ohio, P.O. Box 39158, Cincinnati, OH 45239

65. D. R. Finch, Savannal. River Laboratory, Aiken, SC 29808

66. H. M. Forehand, Los Alamos National Laboratory, P.O. Box 1. 63, Los Alamos, NM 98545

67. D. L. Honkonen, Savannah River Laboratory, Aiken, SC 29808

68. J. A. Irvin-Zamora, Rockwell International, Rocky F':-: Plant, P.O. Box 464, Golden, CO 804 ,

69. N. Ketzlach, Transportation Branch, Office of Nuclear Material Safety and Safeguards, Nuclear Regulatory Commission, MS 396-SS, Washington, D.C. 20555

70. O. C. Kolar, Lawrence Livermore Naiional Laboratory, P.O. Box 808, Livermore, CA 94550

71. B. I.. Koponen, Lawrence Livermore National Laboratory, P.O. Box 808, Livcrmore, CA 94550

12. K. D. Lewis, Goociyear Atomic, Portsmouth, $\mathrm{OH}$

73. J. D. McCarthy, Rockwell International, Rocky Fiats Plant, P.O. Box 464, Golden, CO 80401

74. T. P. McLaughlin, Los Alamos National Laboratory, P.O. Box 1663, Los Alamos, NM 87545

75. R. E. Miles, Rockwell International, Rocky Flats Plant, P.O. Box 464. Golden, CO 80401 
76. J. W. Morfitt, EG \&G Idaho, Inc., P.O. Box 1625, Idaho Falls, ID 83415

77. R. L. Newvahner, Goodyear Atomic, Portsmouth, OH

78. R. H. Odeganden, Transportation Branch, Office of Nuclear Material Safety and Safeguards, Nuclear Regulatory Commission, MS 396-SS, Washington, D.C. 20555

79. J. S. Pearsor, Rockwell International, Rocky Flats Plant, P.O. Box 464, Golden, CO 80401

80. T. H. Figifuru, Universiiy of Cuiifornie, Derixeiey, Cí

81. N. L. Provost, Los Alamos National Laboratory, P.O. Bax 1663, Los Alamos, NM 87545

82. T. A. Reilly, E. 1. DiPont de Nemours Co., Savannah River Plant, Aiken, SC 29808

83. J. N. Rogers, Div. 8324, Sandia Laboratories, Livermore, CA 94550

84. R. Rothe, Rockwell International, Rocky Flats Plant, P.O. Box 464, Golden, CO 80401

85. D. R. Smith, Los Alamos National Laboratory, P.O. Box 1663, Los Alamos, NM 87545

86. B. Waltz, Savannah River Laboratory, Aiken, SC 29808

87. R. E. Wilson, Exxon Nuclear-Idaho Co., P.O. Box 2800, Idaho Falls, ID 83401

88. F. E. Woltz, Goodyear Atomic Corp., P. O. Box 628, Piketon, OH 45661

89-115. Technical Information Center, U.S. Departmeni of Energy, Oak Ridge, TN 37830 